Portland State University

PDXScholar

1987

\title{
An analysis of the eastern margin of the Portland basin using gravity surveys
}

Steven Allen Davis

Portland State University

Follow this and additional works at: https://pdxscholar.library.pdx.edu/open_access_etds

Part of the Geology Commons

Let us know how access to this document benefits you.

\section{Recommended Citation}

Davis, Steven Allen, "An analysis of the eastern margin of the Portland basin using gravity surveys" (1987). Dissertations and Theses. Paper 3788.

https://doi.org/10.15760/etd.5672

This Thesis is brought to you for free and open access. It has been accepted for inclusion in Dissertations and Theses by an authorized administrator of PDXScholar. Please contact us if we can make this document more accessible: pdxscholar@pdx.edu. 
AN ABSTRACT OF THE THESIS OF Steven Allen Davis for the degree of Master of Science in Geology presented June 11 , 1987.

Title: An Analysis of the Eastern Margin of the Portland Basin using Gravity Surveys.

APPROVED BY MEMBERS OF THE THESIS COMMITTEE:

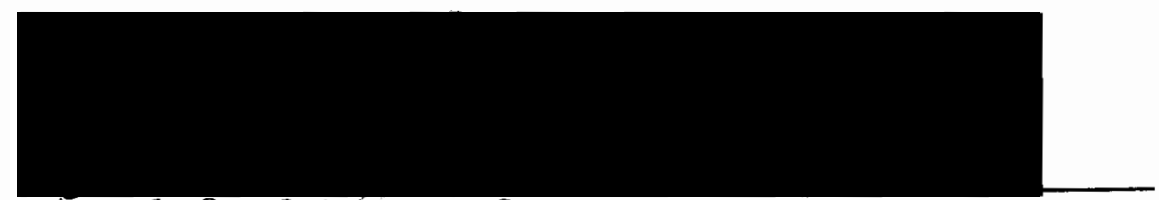

Ansel G. Johtron, Chairman
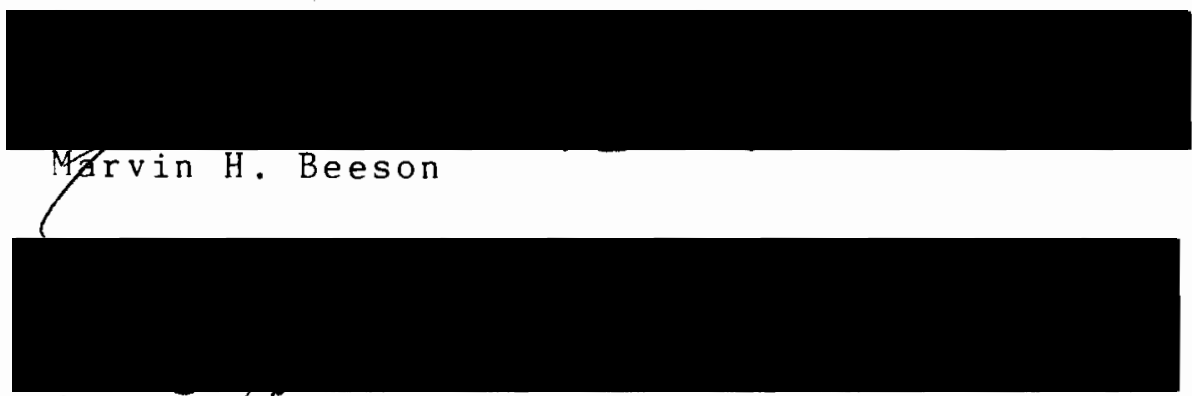

Gilbert'T. Benson

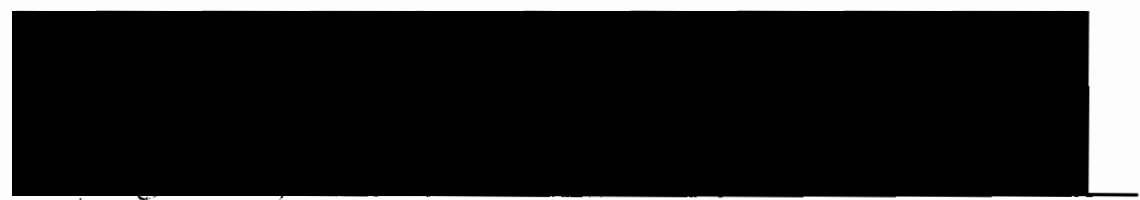

Larry Price

The recent contributions of several investigators has indicated the Portland basin may be a pull-apart structure associated with wrench tectonism. Because of the large density contrast between sedimentary and volcanic units and because of their reasonably uniform and continuous nature, gravity survey methods can be used to identify covered 
structures with considerable success. The study utilized gravity modeling techniques to investigate the structure and genesis of the Portland basin's eastern margin.

Two gravity surveys were completed across pronounced 1 ineaments which form an apparent eastern boundary for the basin. In all, 175 stations were measured, bimodally distributed in regional control and detailed area sections in the $9.47 \mathrm{~km}$ Fourth Plains and $11.43 \mathrm{~km}$ Interstate gravity lines. These values were reduced by standard methods to yield a Free Air gravity anomaly value used in the computer modeling process. The Bouguer gravity was not used since strata normally removed by the Bouguer correction were required for proper interpretation.

Both gravity lines revealed the existence of negative anomalies ranging in magnitude from 1 to 6 mgals, being areally consistent with the locations where the lines crossed 1 ineaments.

Computer modeling indicated these anomalies were produced by strongly prismatic bodies occurring in the near surface section. Some were small enough to be nearly undetectable given survey resolution while others attained cross-sections measuring nearly $3 \mathrm{~km}^{2}$.

Folding, faulting and erosion were investigated as reasonable generative processes for these bodies. Based on the synthesis of modeling and the known geologic history of the region, faulting is preferred. The study defines the 
Lackamas Creek and Sandy River faults. Each can be characterized as an extensive linear zone of locally normal and/or graben like failure where normal displacements approach $300 \mathrm{~m}$. These structures combine to form a region nearly $50 \mathrm{~km}$ in length, trending $\mathrm{N} 40-45 \mathrm{~W}$, effectively paralleling the Portland Hills complex which bounds the basin to the west.

A dextral stepover, characteristic of dextral strikeslip failures and a resulting concentration of extensional deformation is delineated in the region of the Interstate line. Dextral movement is suggested by this incipient pull-apart, the stepover itself and the overall geometry of the faults. 
AN ANALYSIS OF THE EASTERN MARGIN OF THE PORTLAND BASIN USING GRAVITY SURVEYS

by

STEVEN ALLEN DAVIS

A thesis submitted in partial fulfillment of the requirements for the degree of

MASTER OF SCIENCE

in

GEOLOGY

Portland State University

1988 
TO THE OFFICE OF GRADUATE STUDIES:

The members of the Committee approve the thesis of Steven Allen Davis presented June 11, 1987.

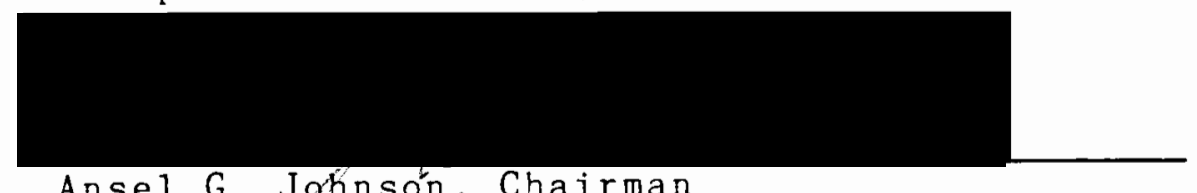

Ansel G. Jothnsón, Chairman

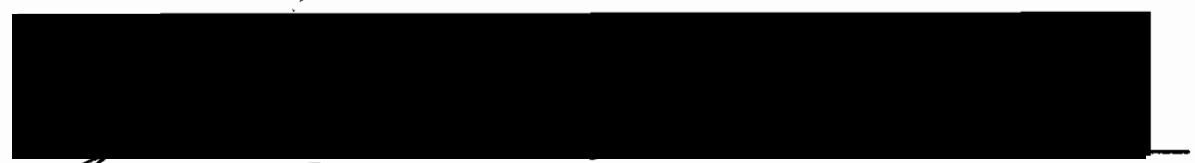

Garvin $H$. Beeson

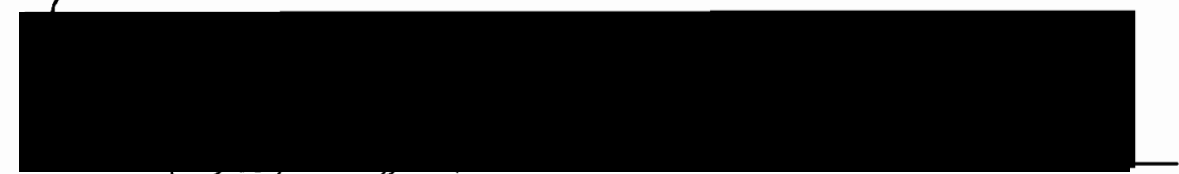

Gilbert P. Bekson

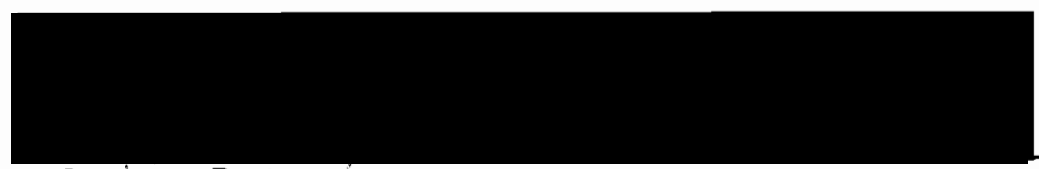

Larry Price/

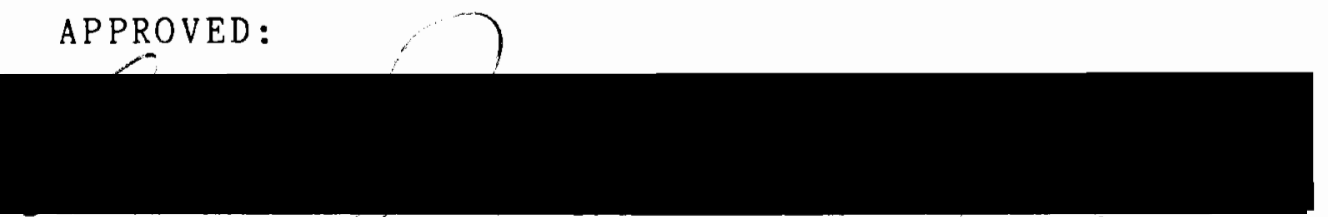

Ansel J. Johnson, Chairman, Department of Geology

Bernard A. Ross, Vice Provost for Graduate Studies 


\section{ACKNOWLEDGEMENTS}

My appreciation and thanks are extended to my advisor, Ansel Johnson, for his guidance and patience. I also thank the members of my committee, Marvin Beeson and G.T. Benson, for their critical reviews. I am particularly appreciative for the many conversations with $\mathrm{Dr}$. Beeson concerning Columbia River basalt stratigraphy and regional tectonics.

Mr. Russ Anderson, of Gaylord Industries, Tualatin, kindly allowed me an open work schedule. This enabled me to attend classes and field exercises. His continual encouragement and support were essential.

Susan Brookfield unselfishly donated time and effort in securing data from the Bonneville Power Administration.

A special thankyou to Karrin Hawes who proved to be a true friend and supporter.

I thank the many past and present students and faculty of the Geology Department. They shared a special time with me and helped me grow. You know who you are and each of you has a part in this.

My particular thanks and love are reserved for my family. My parents $A 1$ and Marriette Davis who recognized my childly interest in the world around me and who nurtured that interest by taking an active role in its development. 
My sons Jesse and Ethan who suffered because of my frequent absence.

Words can not describe the debt I owe my wife Kathy . Without her support and belief in my work I would have quit years before its completion. This is hers as much as mine, she was unfailing.

To Derf, my good friend and mentor, may Pele protect and guide you for the rest of your days.

This research was supported in part by the Paul Howell Fund, administered by the Geology Department, Portland State University. 
TABLE OF CONTENTS

PAGE

ACKNOWLEDGEMENTS . . . . . . . . . . . . . . . . iii

LIST OF TABLES . . . . . . . . . . . . . . . . . vi vi

LIST OF FIGURES . . . . . . . . . . . . . . . . . vii

INTRODUCTION . . . . . . . . . . . . . . . . . . . 1

PURPOSE AND SCOPE OF STUDY . . . . . . . . . . . . 1

LOCATION AND EXTENT OF GRAVITY SURVEYS $\cdot \cdot \cdot \cdot \cdot \cdot \cdot \quad 2$

PREVIOUS WORK . . . . . . . . . . . . . . . . 4 GEOLOGY . . . . . . . . . . . . . . . . . . . 7

STRATIGRAPHY . . . . . . . . . . . . . . . . . 7

STRUCTURE AND TECTONICS

DATA COLlECTION, REDUCTION AND CORRECTION . . . . . . 22

INTRODUCTION . . . . . . . . . . . . . . . . . . 22

THEODOLITE SURVEY MEASUREMENTS . . . . . . . . . . 25

GRAVITY SURVEY MEASUREMENTS . . . . . . . . . . . . 27

GRAVITY MODELING . . . . . . . . . . . . . . . 36

MODELING UNITS AND DENSITIES . . . . . . . . . . 36

REGIONAL MODELS . . . . . . . . . . . . . . . . . 37

COMPLETED LOCAL MODELS . . . . . . . . . . . . 52

INTERSTATE LOCAL MODEL . . . . . . . . . . 52

FOURTH PLAINS LOCAL MODEL . . . . . . . . . . . 67

DISCUSSION AND CONCLUSIONS . . . . . . . . . . . . 76

REFERENCES CITED . . . . . . . . . . . . . . 101

APPENDIX A. . . . . . . . . . . . . . . . . . 106

APPENDIX B . . . . . . . . . . . . . . . . . . . . 126

APPENDIX C . . . . . . . . . . . . . . . . . . 130 


\section{LIST OF TABLES}

TABLE

PAGE

I Gravity measurement error sources . . . . . . . 34

II Stratigraphic modeling units . . . . . . . . . 37

II Parameters for anomaly at km 107.0-111.0 -

Interstate line . . . . . . . . . 62 


\section{LIST OF FIGURES}

FIGURE

PAGE

1. Location map showing study area, lineaments and gravity lines . . . . . . . . . . . . . . 3

2. General geologic map of Portland and vicinity . 8

3. Areal distribution of Columbia River basalt . . 12

4. Map showing distribution of the ancestral

Columbia River and Cascadian stream

facies of the Troutdale Formation . . . . 16

5. Regional Free Air anomaly and elevation profiles

for the Interstate line . . . . . . . . 42

6. Regional Free Air anomaly and elevation profiles

for the Fourth Plains line.........

7. Location of gravity lines with respect to

regional Bouguer gravity . . . . . . . . . . 44

8. Observed and computed regional Free Air gravity

anomaly profiles and regional Free Air

gravity model for the Interstate line . . 45

9. Observed and computed regional Free Air gravity

anomaly profile and regional Free Air

gravity model for the Fourth Plains line. . 46

10. Relationship of the local elevation and Free Air anomaly profiles for the Interstate line. . 
11. Determination of relative magnitudes of local anomalies by adjustment of the regional free air curve... . . . . . . . . . 54

12. A portion of suspected and simplified structure of the Interstate line and the theoretical curve it would generate . . . 57

13. Curve shape generated by a half infinite (in the - $x$ direction) horizontal slab of finite thickness . . . . . . . . . . . 60

14. Observed and computed local Free Air anomaly profiles and completed local model of the Interstate line . . . . . . . . . . 63

15. Observed local Free Air anomaly and elevation profiles for the Fourth Plains line . . . 68

16. Determination of local Free Air anomaly magnitudes by comparison with the computed regional Free Air gravity anomaly curve . . 70

17. Observed and computed local Free Air anomaly profiles and completed local model of the

Fourth Plains line... . . . . . . . 71

18. Stratigraphic nomenclature, age and magnetic polarity for the Columbia River Basalt Group . . . . . . . . . . . . 77 
19. Distribution of major controlling structures and paleo-channels of the Columbia River and their relation to the study area . . . . .

20. Orientations of structures associated with ends of strike-slip faults and stepovers between en echelon strike-slip faults . . . . . . . 94

21. Application of stepover principle to eastern margin and location of control wells . . . 96 


\section{INTRODUCTION}

\section{PURPOSE AND SCOPE OF STUDY}

The Portland Basin is a northwest trending synclinal structure forming the northernmost extent of the Willamette Valley (Beeson and others, 1976). At present the basin can be generally described by two units: a basement composed of Eocene and Miocene volcanics and overlying mid-Miocene \& Pliocene to Recent sediments. Regional tectonic deformation of this basement allowed and controlled the deposition of later units (Trimble, 1963). Overlying sediments fail to reflect structural elements which occur within the basement rendering surface methods of geologic investigation ineffective in revealing the type and extent of deformation.

This study proposes to define the structural relationships of the northeastern margin of the Portland Basin using gravity surveys. Of particular interest are two major lineaments which in this study will be called the Lackamas Creek (LCL) and Sandy River (SRL) lineaments. Gravity surveys are an ideal investigative tool since preliminary geologic and topographic analysis suggests that units with density contrasts as high as $0.5 \mathrm{~g} / \mathrm{cm}^{3}$ could be in juxtaposition. A contrast of this magnitude, if sufficiently close to the surface would produce an 
excellent anomaly.

The integration of these new data with past studies should provide a better understanding of the tectonic history of the Portland Basin and its resultant structure, especially concerning the proposal of Beeson (1985) on its pul1-apart genesis and the possible presence of Hammonds (1971) Yamhil1 - Bonneville lineament.

\section{LOCATION AND EXTENT OF GRAVITY SURVEYS}

The study area encompasses nearly $600 \mathrm{~km}^{2}$ which is divided roughly in half between the eastern portions of Multnomah County, Oregon and Clark County, Washington. Figure 1 defines the study area boundaries and locates both the above mentioned 1 ineaments and gravity lines.

Two gravity lines herein named the Fourth Plains Line and the Interstate Line are the basis for this study. The placement of gravity 1 ines at the onset of a study is crucial. This requires some preliminary knowlege of the geology thereby allowing the researcher to mold his gravity lines to maximize the yield of quality data within the confines of ones resources. While an ideal study would allow positive characterization of all structures with a minimum of gravity stations, in reality considerable chance is involved. The placement of the Fourth Plains and Interstate 1 ines was based on the following general criteria 1) availability of existing geologic data for 


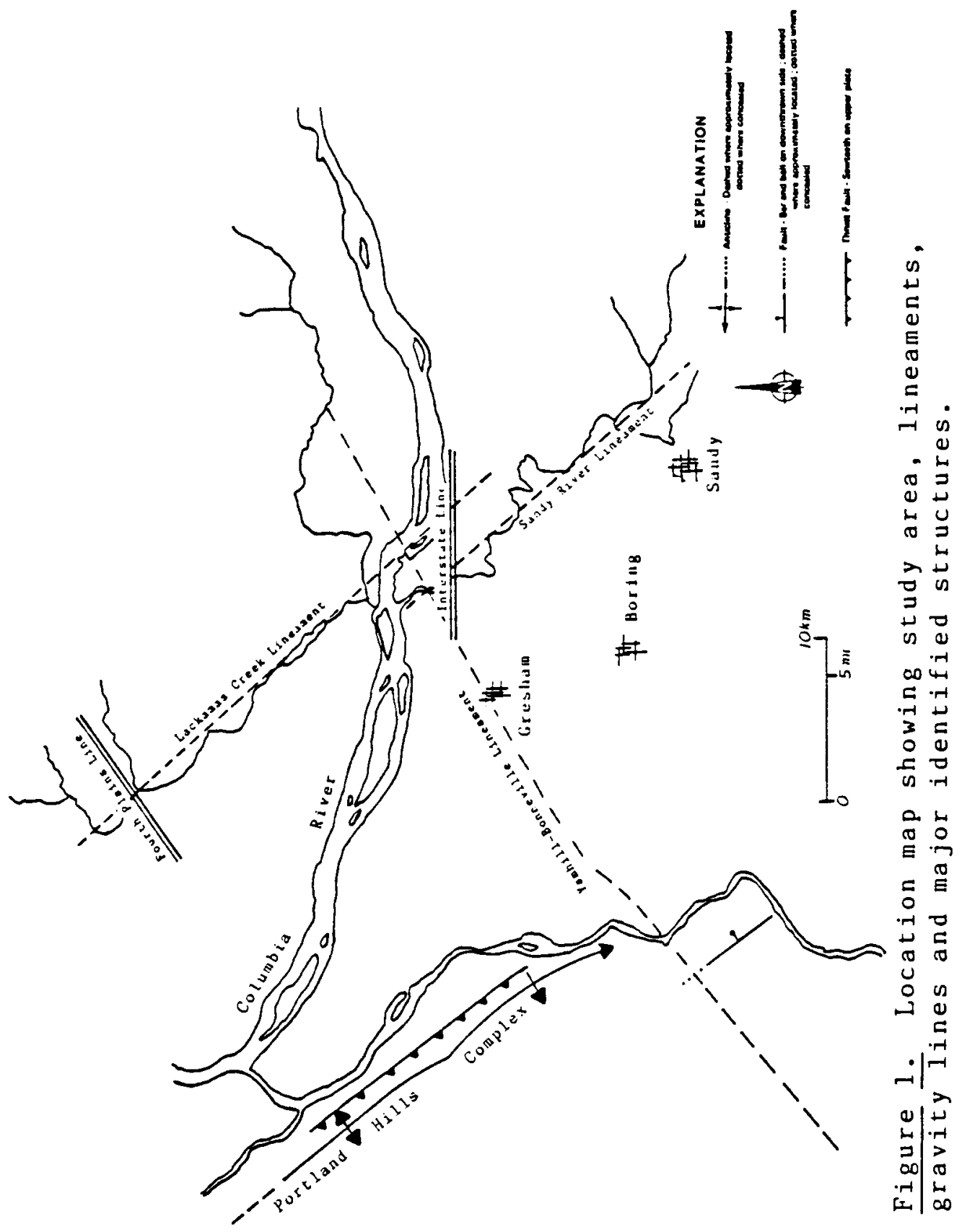


control purposes, 2) proximity to one or both lineaments to maximize the relevence of the data and 3 ) ease of access to make efficient use of limited time and manpower resources.

The Fourth Plains line begins near Sifton, Washington in Section 10, Township 2 North, Range 2 East and extends $9.47 \mathrm{~km}$ northeast into Cascade Mountian foothills at the common corner of Sections 28, 29, 32 and 33, Township 3 North, Range 3 East. The line contains 69 gravity stations surveyed and measured during the fall and winter of 198384. This line was designed to give coverage of the northern extension of the Lackamas Creek lineament.

The Interstate Iine extends from Fairview, Oregon in Section 27, Township 1 North, Range 3 East for $11.43 \mathrm{~km}$ along Interstate 84 to the vicinity of Corbett Station, Oregon in Section 26, Township 1 North, Range 4 East. The line contains 106 surveyed and measured gravity stations collected during the fall and winter 1983-84 season. This line had the twofold purpose of crossing the northern extent of the Sandy River lineament and the southern extension of the Lackamas Creek lineament.

\section{PREVIOUS WORK}

The geology of the Portland Basin and its bordering areas have been mapped by Treasher (1942) and Trimble (1963). A Preliminary Tectonic Map of the Greater Portland Area resulted from the research of Benson and Donovan 
(1974). Studies performed by Beeson and others (1976) indicated that the basin's western margin was faulted, thereby defining the Portland Hills Fault. This

theorization was based on the interpretation of the margin's morphology and certain features of gravity surveys completed across it. Movement was believed to be primarily dextral in nature with a secondary normal component down to the east. Further support for the existence of the fault was provided by Anderson (1978) who delineated a probable southeastern extension into the Clackamas River drainage where sub-horizontal slickensides and apparent large dextral offsets were found. Gravity, refraction and magnetic techniques were employed by Hass (1982) to identify a probable continuation of the feature to the northwest near St. Helens, Oregon. Further disscussion and evidence of the fault and its dextral nature are contained in Tolan and Beeson (1984) and Tolan and others (1984). This study, in agreement with the prominent theory as outlined by these studies, considers the Portland Hills Fault a dextral failure and utilizes this as a premise for furthur interpretation. East - west gravity surveys across the basin have helped to establish stratigraphic relationships (Perttu, 1980).

Regional investigations which provide a geologic framework for the area include those of Diller (1896), Snavely and Wagner (1963) and Newton (1969). Groundwater 
resource surveys in the basin completed by Mundorf (1964), Hogenson and Foxworthy (1965) and Hoffstetter (1982) provide control of sediment distribution and thickness.

The Complete Bouguer Gravity Anomaly and Free Air Anomaly Maps of Oregon prepared by Berg and Thiruvathukal (1967) and the Complete Bouguer Gravity Anomaly Map of Washington by Bonini, Hughes and Danes (1974) provided a base gravity resource for this study. Interpretation of regional gravity by Bromery and Snavely (1964) and Thiruvathukal and Berg (1970) helped establish reasonable limits for regional gravity gradients and prospective modeling depths. 
GEOLOGY

\section{STRATIGRAPHY}

\section{Introduction}

Due to several contributing factors the geology of the Portland Basin is only now becoming understood. The dominant geologic constraint is the widespread distribution of Plio - Pleistocene sediments. Much of the basins' structure is in subjacent Eocene to Miocene volcanics which are mostly concealed. Figure 2 is a generalized geologic map of the area showing the ditribution of major units and their areal relationships to faults, and lineaments.

Numerous shallow groundwater development wells and two deep exploratory wells, the Richfield Oil Barbur \#1 (Barbur well) and the Texaco Inc. Cooper Mountain \#1 (Cooper Mountain well) provide important subsurface geologic data west of the study area. One municipal well, the Fairview well and three Oregon Department of Geology and Mineral Industries heat flow wells (the Corbett Quarry, Howard Canyon and Sandy River we11s) provided local control for the Interstate line. The Fourth Plains line lacks deep well control; but this was not considered critical because:

1) an analysis of topography, geologic contacts, structural 


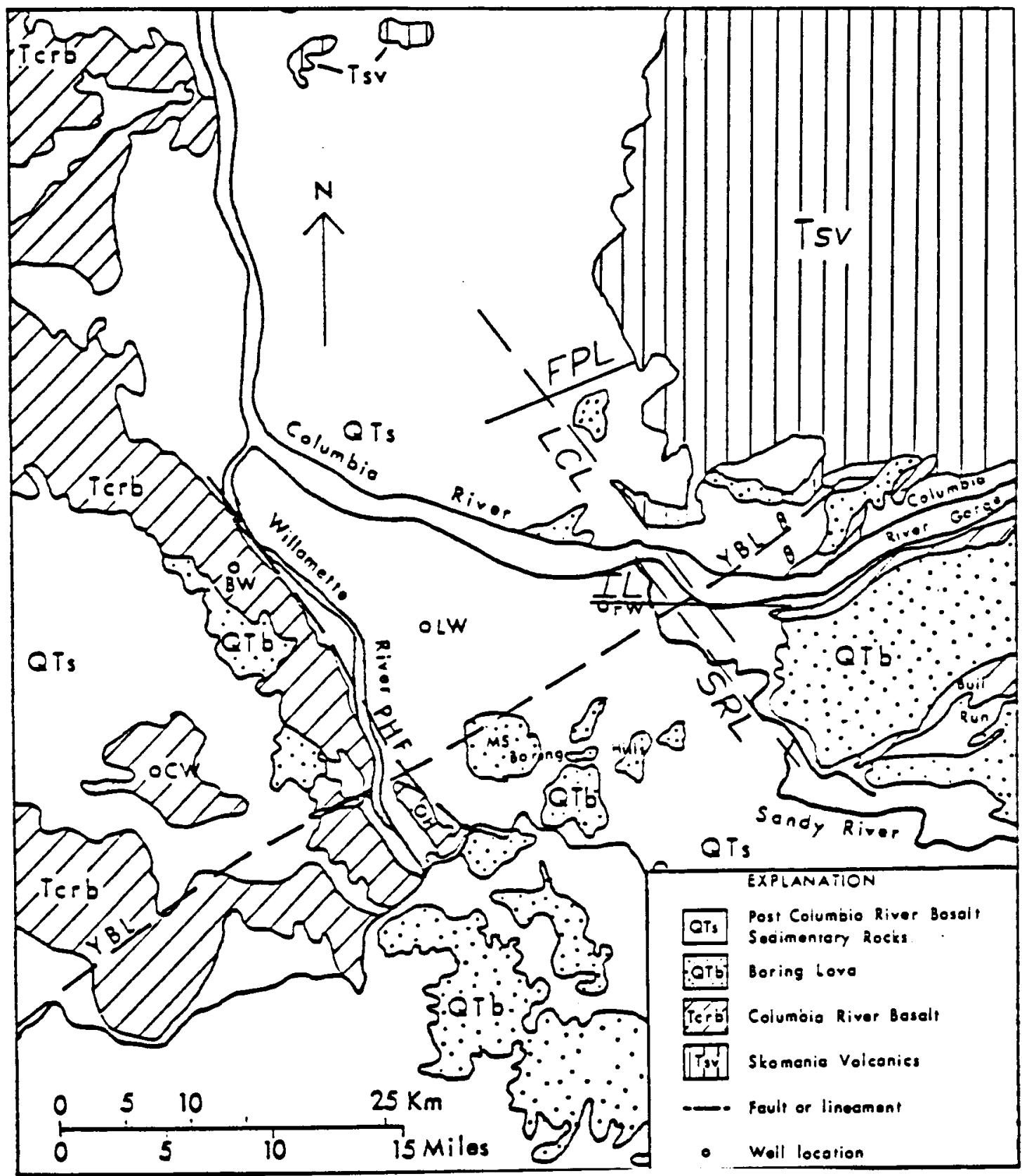

Figure 2. General geologic map of Portland and vicinity (modified from Wells and Peck, 1961 and Huntting and others, 1961). Abbreviations: $\mathrm{BW}=\mathrm{Barbur}$ well; $\mathrm{CW}=$ Cooper Mountian well; $\mathrm{FW}=$ Fairview well; LW = Ladd well; PHF = Portland Hills fault; YBL = Yamhill Bonneville lineament; $\mathrm{FPL}=$ Fourth Plains Iine; IL = Interstate line; LCL = Lackamas Creek lineament; SRL = Sandy River lineament. 
trends and available wel1-based data show no major changes in type, structure or number of units involved and 2) the regional gravity trend is consistent for both 1 ines indicating no great change in structural style.

The following discussion of stratigraphy, structure and tectonic history is an attempt to provide the reader with a basic reference framework while remaining within the scope of the thesis. A treatment of the geology of the Portland area can be found in Trimble (1963) and special emphasis on basalt stratigraphy and structure are found in Beeson and others (1976) and Perttu (1980).

Skamania Volcanic Series

The oldest exposed rocks in the study area are the Eocene to Miocene altered basalts, basaltic andesite flows and related pyroclastic units collectively called the Skamania Volcanic Series by Felts (1939a, 1939b).

The Skamania series is exposed extensively in the northern part of the study area where it forms Cascade Mountain foothills near the eastern end of the North Plains line. There are also 1 imited exposures to the south near Boring, Oregon (Trimble, 1963). Occurrences immediately east of the southern study area are 1 immited to an exposure just east of Crown Point (Tolan, 1982). Beeson and Tolan (1984) speculate that its upper surface acted as the failure plane for a major landslide just east of the end of the Interstate line. The westward extent of this formation 
is poorly understood. Trimble (1963) suggests the Scappoose Formation is a marine equivalent of upper

Skamania series rocks. The Goble Volcanic Series described by Wilkinson (1946) may be correlative with lower Skamania series strata (Trimble, 1963). Goble volcanics have been shown to interfinger with the Cowlitz - Nestucca Formation (Snavely and Wagner, 1964).

The base of the Skamania is not exposed in the study area and therefore its thickness can not be measured directly, but it is probably in excess of two thousand meters (Trimble, 1963). Mapping by Trimble (1963) indicates that the oldest strata to observably overlie the Skamania series is the Troutdale Formation. However, data from the Fairview, Corbett Quarry and Howard Canyon wells place the Columbia River basalt in superposition locally. This relationship has been demonstrated in outcrop by Tolan (1982) some distance east near Breidal Veil, Oregon.

Beck and Burr (1979) do not recognize a Skamania Volcanic Series but rather include these rocks entirely within the Goble volcanics; Hammond (1982) considers them to be part of the Ohanepecosh Formation and Newton (1969) refers to volcanic rocks intercepted in the Barbur well as Goble strata. The terminology of Felts (1939a, 1939b) is retained here, in continuity with previous gravity studies. Since rocks below the Skamania series in the study area are not known, this formation is considered the basal unit of 
detailed modeling.

Columbia River Basalt Group

Locally overlying the Skamania Volcanic Series are tholeitic basalt flows of the Columbia River Basalt Group. These flows represent a portion of a total eruptive volume estimated at $172,000 \mathrm{~km}^{3}$ (Tolan and others, 1982). After originating in the Columbia River Plateau region, various flows followed paths of an ancestral Columbia River west into the Portland area and beyond (Tolan and Beeson, 1984). Figure 3 shows the areal distribution of the Columbia River basalt. In the greater Portland area, trace element and major oxide analysis has been used to discriminate between several members of both the Grande Ronde and Wanapum basalts of the Columbia River Basalt supergroup (Beeson and others, 1976; Tolan and Beeson, 1984 and Beeson and others, $1985)$.

The Columbia River basalt has a limited exposure in the study area, occurring near the eastern end of the Interstate line in the cliffs along the southern shore of the Columbia River and as a small exposure along the Sandy River at the southern boundary of the study area (Trimble, 1963). The Columbia River basalt is encountered in the Fairview, Corbett Quarry and Howard Canyon wells, and in several groundwater wells in the Portland basin. Based on these well data and extensive exposures in the Portland 


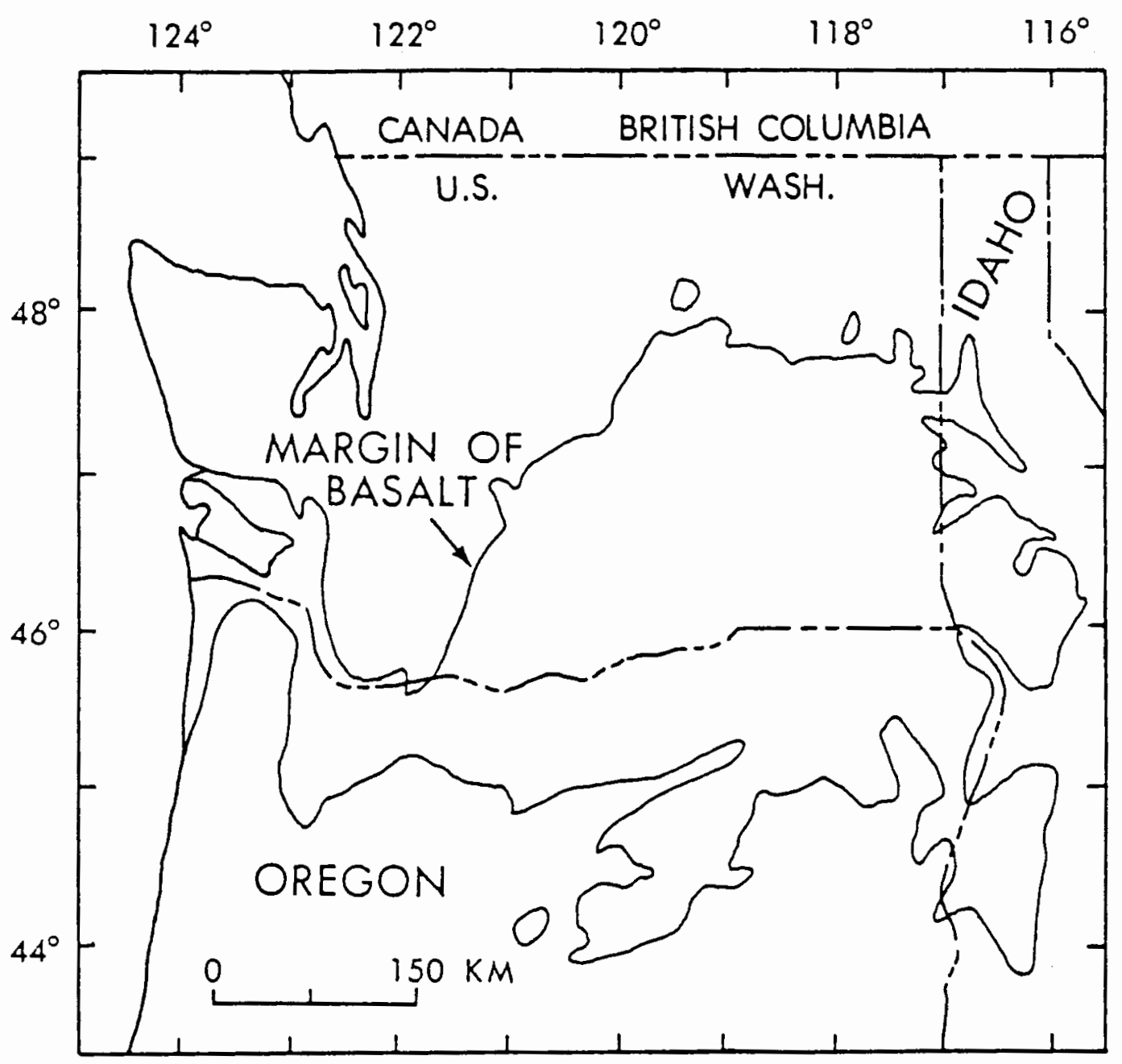

Figure 3. Areal distribution of Columbia River basalt (from Tolan and Beeson, 1984). 
Hills, the Columbia River basalt is interpreted to underlie the entire Portland Basin (Trimble, 1963; Beeson and others, 1976 and Perttu, 1980). However, no exposures of the Columbia River basalt are known in the study area north of the Columbia River. This is likely due to one or more factors which may include: 1) erosion - locally several members of the basalt are represented as intracanyon flows and destruction of these paleo-channels by erosion has been a major hinderence to tracing their paths westward (Beeson, pers. comm., 1985), 2) pinchout - the present course of the Columbia River through the Cascades approximates a topographic transition zone which during the Miocene divided a paleo-low in Oregon from an apparent paleo-high in Washington causing exclusion of the basalt (Tolan and Beeson, 1984) and 3) misidentification - it seems probable that in the past some Columbia River basalts have been confused with basalts of the Skamania volcanics and/or the Boring lavas, particularly before the advent of modern chemical identification methods. The Columbia River basalt attains an apparent maximum thickness within the basin of $310 \mathrm{~m}$ in the Cooper Mountain well. Greater thicknesses are found in the Columbia River Gorge but are due in part to overthrusting (Anderson, 1980).

East of the Portland Basin the Columbia River basalt is underlain by Skamania series strata (Tolan, 1982) but within the basin itself Skamania rocks are largely replaced 
by undifferentiated Eocene to 01 igocene sedimentary rocks (Newton, 1969; Perttu, 1980).

The Columbia River basalt is unique in that it is the only competent unit which demonstrates the shape and structure of the basin in cross section (Trimble, 1963;

Beeson and others, 1976; Perttu, 1980), therefore making it of primary importance to this study.

Post Columbia River Basalt Sedimentary Rocks

Overlying the Columbia River basalt are Mio-Pliocene lacustrine deposits of the Sandy River Mudstone, the deposition of which was controlled by a developing Portland Basin (Trimble, 1963). Previously included as part of the Troutdale Formation, Trimble (1963) thought differences in lithology and genesis significant enough to separate it from younger strata. The Sandy River Mudstone is best exposed in the canyons of local rivers and streams, especially that of the Sandy River for which it is named. The maximum exposed thickness is $100 \mathrm{~m}$ in the valley of Buck Creek, a tributary of the Sandy River, and the total inferred thickness of approximately $230 \mathrm{~m}$ was suggested by Trimble (1963) on the basis of water well data. The Sandy River Mudstone is restricted to deep portions of the Portland Basin as evidenced by its absence from structural highs both to the east and west.

The Sandy River Mudstone and Columbia River basalt are overlain by $P 1$ iocene sandstones and conglomerates of 
the Troudale Formation. The Troutdale Formation was described by Hodge (1933) and was named for the excellent exposures occurring in the cliffs above the Sandy River near Troutdale, Oregon. The formation consists of two lithologically distinct facies (Figure 4). The first is characterized by conglomerates exhibiting foriegn clasts, such as quartzite, schist and granite, for which there are no local sources (Tolan and Beeson, 1984). This facies represents deposits of an ancestral Columbia River and is confined to an area near the present river channel (Trimble, 1963). The second younger facies is characterized by conglomerates composed of only locally derived clasts and represents deposits of paleo-Cascade streams which drained into the Willamette Valley (Baldwin, 1981).

The Troutdale is exposed extensively throughout the eastern half of the Portland basin. In the study area it forms Cascade Mountain foothills in the north and cliffs above the Sandy and Columbia Rivers to the south. Both the North Plains and Interstate lines either traverse or skirt exposures of this formation.

\section{Boring Lava}

Over the period from $10 \mathrm{~m} \cdot \mathrm{y} \cdot \mathrm{b} \cdot \mathrm{p}$. to $1 \mathrm{~m} \cdot \mathrm{y} \cdot \mathrm{b} . \mathrm{p}$. (Trimble, 1963) Boring lavas and pyroclastics were produced from 90 known vents in the Portland area (Allen, 1975). 


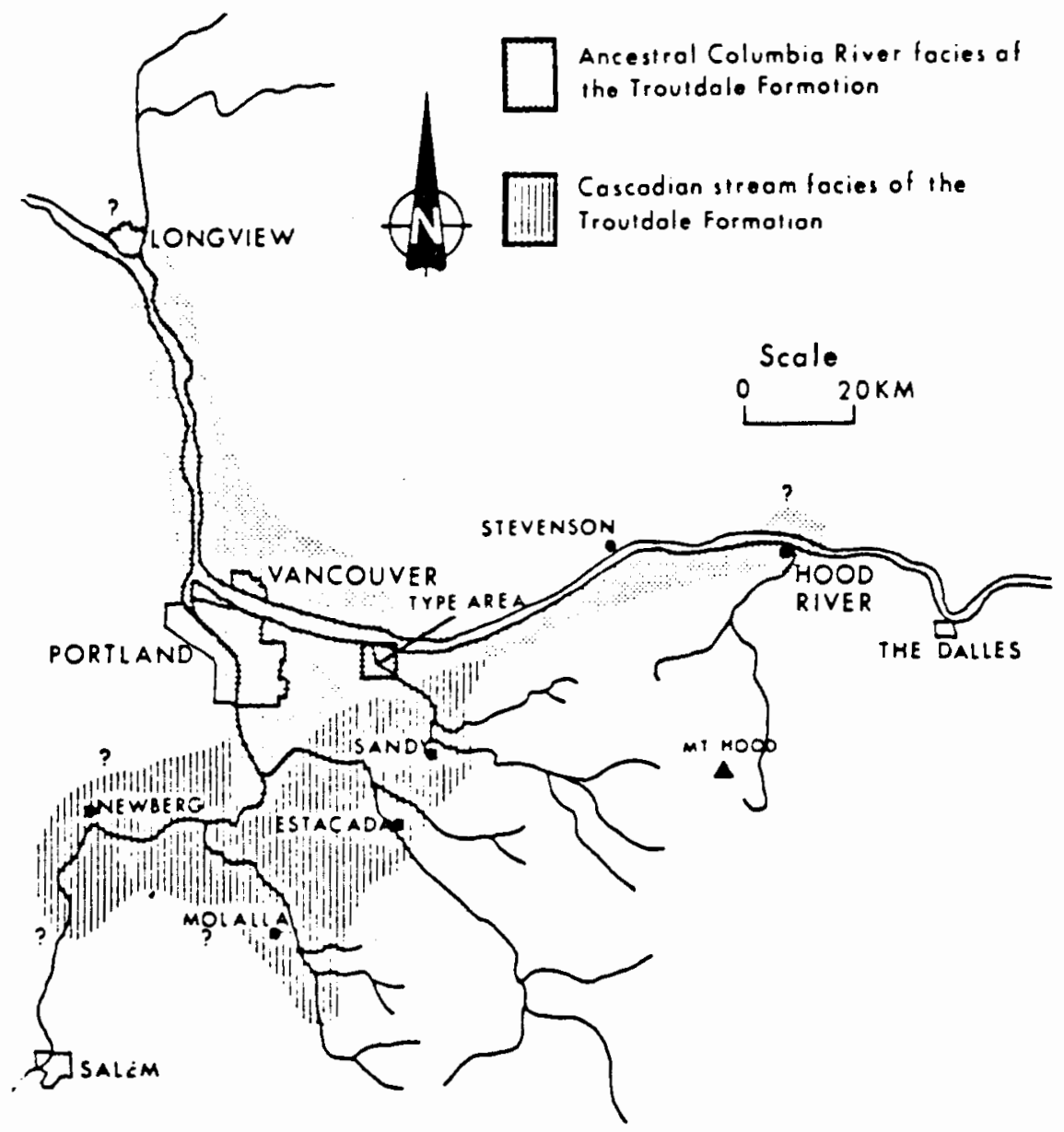

Figure 4. Map showing distribution of the ancestral Columbia River and Cascadian stream facies of the Troutdale Formation. (from Tolan and Beeson, 1984) 
The Pliocene to Pleistocene Boring lavas are commonly high alumina, light gray, olivine basalt with a pilotaxitic to diktytaxitic texture (Trimble, 1963; Tolan and Beeson, 1984). The basalts were named by Treasher (1942) for a concentration of 20 vents near the community of Boring, Oregon.

Morphologically the Boring Lavas are represented by cinder cones and shield volcanoes, producing buttes and high lava plains respectively (A11en, 1975). The Boring lava primarily overlies the Troutdale Formation and to a minor local extent, younger Pleistocene sediments ( Trimble, 1963).

Unlike the Columbia River Basalt flows which traveled more than $100 \mathrm{~km}$ to reach the Portland area, the Boring lavas were erupted locally, possibly along structural zones of weakness (Beeson and others, 1976). The existence of a magma chamber which could possibly supply one or more eruptive centers was suggested by Perttu (1980) in an attempt to explain an elongated gravity high beneath the Portland Basin. The existence of such a chamber or chambers seems possible, however, this hypothesis has not been proved nor has any relationship between structural trends and the distribution of vents been demonstrated.

\section{Pleistocene To Recent Sediments}

Several Pleistocene sedimentary formations have been described by Trimble (1963), including the Walter's Hill, 
Springwater, Gresham and Estacada Formations. The occurrence of these units in extent and volume within the study area is minor. Consequently these formations will not be described and delineated here but will be considered part of older more voluminous units.

\section{STRUCTURE AND TECTONICS}

In light of the incomplete nature of current knowledge, a rather conservative depiction of structure and tectonics is presented here.

In early Eocene time a subduction zone existed just west of the present Cascade Range (Atwater, 1970). The Siletz River and Tillamook Volcanic Series moved toward this trench as oceanic tholeiites of the paleo-Farallon Plate (Snavely and others, 1968; Drake, 1982).

During middle to late Eocene time a fore-arc basin was formed which received turbidites of the Flournoy and Tyee Formations (Drake, 1982). The development of this basin presumes the existence of an outer high or arc. It is the genesis of this arc which remains unclear, yet is crucial to proper interpretation. Some have suggested jamming of the subduction zone by seamounts (Perttu, 1976) or an aseismic ridge (Simpson and Cox, 1977) with a subsequent shift of the subduction zone to a position west of the present coast. Such a scenario could begin forming 
a fore-arc basin simply from the relief of the trench jamming feature. Subsequent underthrusting would then have accomplished uplift of the Coast Range by late Oligocene time. Drake (1982) sites this imbricate underthrusting as the generative process for the outer arc. The point of contention seems to be whether the Siletz - Tillamook volcanic pile represents material which has been sheared from the surface of a subducting plate or, a1ternatively, that it remains attached to tholeiitic material at depth. The former concept does not require a shifting subduction zone but rather very shallow subduction which produced the outer arc through shearing (Siletz - Tillamook volcanic pile) and imbricate underthrusting. The latter assumes the Siletz - Tillamook volcanics were resilient enough to resist shear, forcing the subducting plate to rupture forming a new subduction zone to the west (the afore mentioned shift) while leaving the volcanics attached to a stranded micro-plate accreted to the continental margin. In either case it seems probable that a significant degree of subsequent underthrusting was responsible for the Coast Range uplift (Snavely and others, 1968).

A further complication is the 50 to 70 degree rotation of the Coast Range block from its Eocene magnetic direction (Simpson and Cox, 1977). Rotation appears to have been simultaneous with the deposition of formations within the fore-arc basin as evidenced by a systematic decrease in 
the degree of rotation in younger units. Drake (1982) suggests rotation about a southern axis located at the northern boundary of a stationary Klamath Mountain block. Magil1 and Cox (1980) have demonstrated that the Cascade Range has rotated with the Coast Range but maintain the axis 1 ies to the north in southwest Washington or northwest oregon. They speculate that north of this region, smaller blocks displaying varied degrees of rotation are characteristic. Beck and Burr (1979), for example have shown the Skamania Volcanics have rotated independently of the Coast - Cascade Range block. Magill and Cox (1980) point out that northwesterly movement of the Sierra Nevada associated with basin and range extension is the likely cause of Miocene to Recent north - south compression of the Columbia Plateau. This stress could be genetically related to that which is responsible for the existence of large scale northwest trending structures throughout Oregon. This regional shear might be expressed in the present structure of the Portland Hills Fault Zone. Identified faulting within the zone includes both right lateral shear of $10 \mathrm{~km}$ and normal displacements, generally down to the east, as great as $300 \mathrm{~m}$ (Beeson and others, 1976). Anderson (1978) has found evidence of right lateral shear in the Clackamas River drainage, on strike with the Portland Hills structural trend. Generation of the Portland Hills Fault Zone and its related structures 
spanned Miocene time as evidenced by its strong influence over the local occurrence of particular Columbia River Basalt flows (Beeson and others, 1976; Tolan and Beeson, 1984). Beeson and others (1985) envision the Portland basin as a Miocene pull-apart basin genetically related to the then active Portland Hills - Clackamas River structural zone. 


\section{DATA COLLECTION, REDUCTION AND CORRECTION}

\section{INTRODUCTION}

Gravity methods involve the measurement of minute changes in the relatively large gravitational field of the earth. These changes are due in part to density (and therefore mass) variations within the asthenosphere and lithosphere. The basis for gravity work is the expression for the force of gravitation given by Newton's law, from Telford (1976)

$$
F=-\gamma \frac{m_{1} m_{2}}{r^{2}} \hat{r_{1}}
$$

where $F$ is the force (dynes) on $m_{2}, \hat{r}_{1}$ is a unit vector from $m_{1}$ to $m_{2}, r$ is the distance between $m_{1}$ and $m_{2}$ and gamma is the universal gravitational constant which has a value of $6.67 \times 1 \sigma^{-8}$ dyne-c $\pi^{2} / g m^{2}$.

The gravitational acceleration $g$ of $\mathrm{m}_{2}$ at the earths' surface can be found by the expression, from Telford (1976)

$$
g=\frac{F}{m e}=-\gamma \frac{M_{e}}{R_{e}} \hat{r}
$$

where $m_{1}$ becomes Me, the mass of the earth, $r$ becomes Re, the radius of the earth and $\hat{\xi}$ extends from the earth's center out along it's radius.

The value of $g$ at the earth's surface is about 980 $\mathrm{cm} / \mathrm{sec}^{2}$ and the unit of gravitational acceleration, 1 
$\mathrm{cm} / \mathrm{sec}^{2}$, is called the gal in honour of the early investigator, Galileo. Gravity meters (gravimeters) measure variations of this acceleration as small as $10^{-5}$ gals which corresponds to one part in $10^{8}$ of the earth's total field (Telford, 1976).

While the causes of various changes in the earth's gravitational field are many, gravity methods are ultimately concerned only with those changes produced by lateral density variations in the lithosphere (crust). These variations, or anomalies, commonly have a structural or structurally related developmental history. The Portland Basin is ideal for study by gravity methods. Faulting has brought low density rocks of the Sandy River Mudstone and Troutdale Formation into juxtaposition with high density flows of the Columbia River basalt and Skamania volcanics. Beeson, and others (1976) and Perttu (1980) have demonstrated success in the delineation of faults within the Portland basin using gravity surveys.

A potential shortcoming of the gravity technique is "lithologic blindness", which is the inability of the method to distinguish between two or more formations which do not differ significantly in their densities. Such situations occur in the study area where Columbia River basalt overlies Skamania volcanics and where the Troutdale Formation overlies the Sandy River Mudstone. Since the densities of these pairs of formations are similar, it not 
possible to use gravity to recognize individual formations in all circumstances. However, the primary goal of delineating sediment from volcanics can be achieved.

Initially, three gravity lines were to be included in this study. The Bull Run line was originally designed to cross the Sandy River lineament at its southernmost extension near Sandy, Oregon. In this orientation the line would combine with a previously collected but not modeled data set (Jones, 1977). Although measured, the Bull Run line failed in three ways: 1) geologic control - when viewed collectively with the other lines, the quality of geologic control was notably poorer 2) station spacing the line was coincident with the Bonneville Power Administration, Hanford Ostrander transmission line providing pre-surveyed station elevations at each tower, however, station spacing was three times that in the other lines causing the resolution of the final model to suffer and 3) incompatable data - large discrepancies between stations measured by Jones (1977) and remeasured by the author cast considerable doubt that the two data sets could be combined with a reasonable degree of confidence. Since one has no exact knowlege of how much preliminary geology must be known, what station spacing is adequate to describe the anomalies dicovered, or whether a previous data set is reliable, these problems are largely unforseeable until the measurements are made. Because of these complications the Bull Run line is not included here. 


\section{THEODOLITE SURVEY MEASUREMENTS}

Data Collection

A precise location and elevation must be known for every gravity station before fundamental corrections can be made to gravity measurements. Stations must be located within $12 \mathrm{~m}$ ( $40 \mathrm{ft}$ ) north - south distance and $0.05 \mathrm{~m}$ ( 2 in) in elevation so that gravity measurements can be accurate to within $0.01 \mathrm{mgals}$, the sensitivity of modern gravity instruments (Telford, 1976).

Both gravity lines were surveyed with a Wild T2 Theodolite and stadia rods. The theodolite measures three quantities: 1) distance between the instrument and rod 2) vertical angle and 3 ) horizontal angle. The horizontal distance is determined by applying an appropriate mathematical expression to the numerical interval intercepted on the rod by crosshairs within the theodolites telescopic sight. This method is limited to about $30 \mathrm{~m}$. Much greater distances were desired so moveable flags were attached to the stadia rod and directions via tranciever were given until crosshairs and flags were coincident; the rodman then read stadia intercepts back to the recorder. This method increased the effective distance of the instrument to over $300 \mathrm{~m}$.

Vertical control for the Fourth Plains line was obtained from a United States Geological Survey (USGS) brass disk (sta.\#1), elevation $138.67 \mathrm{~m}$ (455ft) and a 
temporary benchmark (sta.\#60) placed by the Washington Department of Transportation, elevation $67.58 \mathrm{~m}$ (221.74ft). Vertical control for the Interstate line was provided by an Oregon Department of Transportation brass disk (sta.\#.01), elevation $30.86 \mathrm{~m}(101.25 \mathrm{ft})$. A11 benchmarks in both surveys used a common base level, the USGS National Geodetic Vertical Datum of 1929.

Reduction

To become suitable for use in gravity work theodolite data must be reduced to precise latitudes, longitudes and elevations. The execution of this process is both tedius and complex. Indeed, this is the single most time consuming and error prone step of any in the study. Prior to this thesis the majority of calculations and compilations applied to theodolite data were done manually.

The FORTRAN program WINGS was developed for the study to accomplish these tasks with the speed, accuracy and precision obtainable on 1 y with digital methods. The program allows the user to enter field data directly from an instrument book into an input file without previous modification. WINGS will calculate and list twenty five different intermediate variables and values giving the user a continuous check on data quality. The final output consists of a latitude, longitude and instrument error corrected elevation for every station. A listing of WINGS appears in Appendix A. 


\section{GRAVITY SURVEY MEASUREMENTS}

\section{Data Collection}

A11 gravity measurements were made with a Worden Gravity Meter, Master Model III (loaned by Oregon State University) which has a sensitivity of $0.1374 \mathrm{mgals} / \mathrm{scale}$ division. Three meter measurements in agreement within 0.2 scale divisions were taken at each station providing an averaged precision of $\pm 0.027 \mathrm{mgals}$. The gravimeter was kept thermally stable by an internal 12 volt heating element. Meter temperature was recorded at each station for application to a temperature correction table.

Selected field stations were reoccupied every two hours each day so that daily instrument drift curves could be constructed. A base gravity station in the lobby of the Geology Department, Portland State University, with an absolute gravity value of 980641.35 mgals was measured at the beginning and end of each field day. This provided a known base gravity value later used to determine absolute values of field stations.

Station spacing in both lines consisted of two basic parts: 1) a detailed portion with stations spaced every $100 \mathrm{~m}$ and 2) a control section extending out in both directions from the detailed area, with spacing every 200 m. If station spacing is not sufficiently close, then gravity anomalies might be inadequately represented or go undetected entirely. 
Time Dependent Correction

A time dependent instrument drift correction must be applied to each gravity measurement. This drift has two causes: 1) mechanical - the gravimeter has many internal components which are sensitive to temperature, motion etc. and 2) earth tides - which are the combined effect of lunar and solar gravitation on the earths own gravitational field.

Fortunately these factors change slowly, (approximate 12 and 24 hour periods) usually in a sinusoidal manner, and so can be combined in one adjustment. Seven instrumental drift curves were constructed and the appropriate drift was removed from each field reading. Drift rates varied from a maximum of $0.120 \mathrm{mgals} / \mathrm{hr}$ to a minimum of $0.023 \mathrm{mgals} / \mathrm{hr}$ with a mean value of $0.079 \mathrm{mgals} / \mathrm{hr}$.

\section{$\underline{\text { Latitude }}$ Correction}

Both the rotation of the earth and its equatorial bulge cause gravity to increase with latitude. Earth rotation causes centrifugal acceleration which opposes gravitation. This condition has a maximum value at the equator while being zero at the poles.

The earth's radius is greatest at its equator. This additional distance from the earth's center decreases gravity while the corresponding greater mass causes a gravity increase. From (2) we have $g \propto M e$ and $g \propto 1 / \mathrm{Re}^{2}$, therefore the mass increase can only partially counteract 
the radius effect.

The combination of these characteristics leads to an overall decrease in gravity with decreasing latitude. This lends itself to a correction based on $\varnothing$ the latitude, given by $0.8212 \sin 2 \varnothing \mathrm{mgals} / \mathrm{km}$ (Telford, 1976).

Free Air Correction

Since gravity varies inversely with the square of distance it is necessary to make adjustments for the elevation difference between stations. In practice all stations are corrected to a common datum elevation; in this study that datum was sea level. This adjustment does not take into account the material between the station and datum plane, hence the term "free-air". The correction has a value of $-0.3085 \mathrm{mgals} / \mathrm{m}$ which is added to the field reading when the station is above the datum plane and subtracted when below. The resulting reduced gravity is called the Free Air Gravity. A value derived from this, called the Free Air Anomaly, was used for modeling and interpretation in this study.

\section{Bouguer Correction}

The Bouguer correction accounts for the attraction of material between the station and the datum plane. It has a value of $0.04188 \sigma \mathrm{mgals} / \mathrm{m}$, where $\sigma$ is the material density. The correction is subtracted when the station is above the datum plane and added when below it. The Bouguer 
adjustment was not applied to data in this study since material of interest was at or above the sea level datum and its removal would complicate interpretation and modeling.

\section{Terrain Correction}

This correction quantifies the effects of topographic irregularities in the vicinity of a station. Any gravity measurement is composed in part, of contributions made by a lack of mass (valleys) and or an excess mass (mountains) in the immediate area of that station. The combined effect of these features, lack of mass pulling down and excess mass pulling up, tend to decrease the gravity value. Because of this, terrain corrections are always added to the station reading.

Terrain corrections are usually not incorporated in free air gravity studies. Gravity modeling is done in two dimensions with the third dimension assumed infinite. This third dimension is also assumed to posess geology which is both perpendicular to and homogenous with geology contained in the cross sections modeled. Using free air techniques, all the topography and the material above or below the datum plane which produced it are incorporated in the mode1. Terrain corrections in effect remove the topography that free air modeling relies upon. Free air gravity lines which intersect, in a perpendicular sense, the long axis of topographic features are ideal since they satisfy the 
assumptions of perpendicularity and homogeniety. In some cases, such as the Interstate line, terrain corrections may be necessary. The eastern half of this line parallels a prominent cliff (excess mass) composed of Columbia River basalt, the Troutdale Formation and Boring lava. This material, because of its proximity, no doubt decreased the measured gravity for stations \#23 thru \#91 significantly.

Several graphical methods are available for the determination of terrain corrections. The method of the half infinite slabs as described in Telford (1976) was applied to several cross sections. Examples of the procedure can be found in Appendix B. This method was chosen for two reasons: 1) the available geologic data indicated the cliff could be validly assumed to be composed of infinitely long slabs of finite thickness and 2) this method allowed relatively rapid assessments of the gravitational contribution of several sections of the cliff. Fifteen cross sections of the cliff were analysed. They were selected because they marked abrupt changes in lithology and or topography. The terrain effect of intervening stations was extrapolated.

Computer Assisted Corrections

The FORTRAN program GRAVPLOT (Jones, 1977) was utilized to apply several of the proceeding corrections. When supplied with station elevation, latitude, observed absolute gravity and terrain corrections the program 
calculated a theoretical gravity, Free Air Correction, Free Air Anomaly, Bouguer Correction, Simple Bouguer Anomaly and Complete Bouguer Anomaly value for each station. These data are listed in Appendix C.

The calculation of theoretical gravity is based on a mathematical model of the earth in which the force of gravity is always normal to the models' surface. This equipotential surface is related to sea level where the earth's surface has been smoothed to eliminate mountains and oceans (Telford, 1976). The expression used to find $g$ at any point on this surface is given by, from Telford $(1976)$

$$
g=g 0\left(1+\alpha \sin ^{2} \phi+\beta \sin ^{2}(2 \phi)\right)
$$

where $\varnothing$ is the latitude, go the equatorial gravity is $978.049 \mathrm{gals}, \alpha$ a constant is 0.0052884 and $\beta$ also a constant is -0.0000059 . These constants have been updated (after 1967) but are retained here for continuity with previous gravity studies and published gravity maps of Oregon.

The theoretical and observed absolute gravities in conjunction with other applicable corrections for each station are used to calculate the Free Air, Simple Bouguer and Complete Bouguer Anomalies. These three values are the desired culmination of the rather extensive corrections and reductions made to gravity measurements. The relationship used to find $g_{F A A}$, the Free Air Anomaly is, modified from 
Telford (1976),

$$
g_{F A A}=g_{O D S} \pm d q_{L}+d g_{F A}-g r
$$

where $g_{\text {obs }}$ is the observed absolute gravity, dg is the latitude correction, $d g_{F A}$ is the free air correction, and $\mathrm{gr}$ is the calculated theoretical gravity from ( 3 ). In (4) the temperature, drift and terrain corrections have been previously determined.

It is apparent upon inspection of (4) that $g_{F A A}$ represents a value which has been corrected for all phenonema which effect gravity measurements except lateral density changes in the lithosphere. This value, when adjusted for regional fluctuations, is used for modeling in this study.

\section{Estimation of Error}

Quantification of error in gravity surveys depends on how well the various sources of error lend themselves to statistical techniques. In this study it is assumed that these error sources behave in a random manner and can be characterized by a normal distribution. If this is so then the following are true: 1) a positive error has the same probability of occurrence as a negative one 2) small errors will occur more frequently than large ones and 3 ) very large errors do not occur, or at least the probability that they will is small. We can also state that the largest error possible corresponds to the event where the sources 
of error are either all positive or negative, thereby eliminating their mutual cancellation.

These errors are then subject to the principle of least squares which states that the event which has the maximum probability of occurrence is the one in which the sum of the squares of the errors is a minumum. Derived from this condition is the relationship which describes the probable error of the sum of several measurements, in Bouchard (1965),

$$
E_{s}=\sqrt{\varepsilon_{1}^{2}+\varepsilon_{2}^{2}+\ldots+\varepsilon_{n}^{2}}
$$

where the probable error of each measurement is designated by E and a subscript.

The identified sources of error in this study are shown in Table I.

TABLE I

GRAVITY MEASUREMENT ERROR SOURCES

ERROR SOURCE

ERROR VALUE (mgals)

instrument reading

$\pm 0.027$

elevation

$\pm 0.001$

latitude

$\pm 0.01$

instument drift

$\pm 0.01$

terrain correction

$\pm 0.03$

Each has a corresponding value in milligals which is 
thought to best represent the maximum reasonable error associable with each source. From the application of (5) we can assume that a possible error of $\pm 0.06 \mathrm{mgals}$ can be associated with each station. 


\section{GRAVITY MODELING}

\section{MODELING UNITS AND DENSITIES}

In gravity modeling, any formation or part thereof which has a density in contrast with its surroundings can be defined as a unique modeling unit (block). This means that a block may include one or several formations, either entirely or partially, in any combination.

It is significant to note that gravity models are dependent only on the occurrence of density contrasts and contain no primary information concerning the genesis, lithology or diagenesis of the units which cause these contrasts. Because of this, meaningful block parameters can not be derived from the gravity profile alone. Only upon the synthesis of the gravity profile with known geology can the dimensions and extent of modeling blocks be determined.

Block shapes are neccessarily simple because properties like depth, density and volume tend to obscure the more subtle characteristics of unit contacts. Boundaries between units are therefore straight lines, even though a significant amount of interfingering may be present.

Table II 1ists the stratigraphic modeling units used in this study. The densities which appear here are based 
on data from Bromery and Snavely (1964) and are consistent within $\pm 0.1 \mathrm{~g} / \mathrm{cm}^{3}$ of values used by Beeson and others (1976), Jones (1977) and Perttu (1980).

\section{TABLE II}

STRATIGRAPHIC MODELING UNITS

STRATIGRAPHIC UNIT
DENSITY

$\mathrm{g} / \mathrm{cm}^{3}$
GEOLOGIC

ABBREVIATIONS

Alluvium - unconsolidated

2.0

Qa1

material

Sedimentary Rocks - Portland and Tualatin Basins (Troutdale

Formation, Sandy River Mudstone

2.4

QTS and equivalents, etc.)

High Cascade volcanics (Boring Lavas, Rhododendron Formation and equivalents, etc.)

2.4

QTves

Intrusive rocks

3.1

QTi

Pre-Columbia River basalt

Cascade sediments (Eagle Creek

2.4

Tec-sr and Stevens Ridge Formations

and equivalents, etc.)

Columbia River Basalt Group

2.8

Tcrb

Skamania Volcanic Series

2.8

Ts v

Tillamook Volcanic Series

2.8

Ttv

Importance

Regional modeling is a neccessary and crucial step in the execution of the gravity technique. Because of their 
subjectivity, regional models are often poorly received. Regional models represent generalized geologic cross sections of a particular portion of the lithosphere. It is a fundamental premise in gravity modeling that no solution is unique and many block combinations can be found to satisfy a given gravity profile. At its worst the solution may have no resemblence to reality; at its best it approximates existing geology. The regional model succeeds only if it places the local model in a realistic geologic framework, isolating it from regional effects.

Accomplishment of this not only facilitates local modeling but greatly enhances confidence in the validity of final models and the conclusions drawn from them.

Before local gravity modeling can begin, each local line must be placed within a regional model. This integration is done for the following reasons:

1) Edge effects, a phenomena encountered at the "edges" of a gravity model, must be compensated for. The large density contrast (rock vs void space) encountered at this transition has a significant effect on a gravity profile computed nearby. The effect is expressed as a sharp decrease in calculated gravity values many orders of magnitude greater than typical anomalies of interest. By placing the relatively short local line inside a regional model of much greater length, local anomalies are far removed and insulated from edge effects. 
2) Determination and removal of regional gradients must be accomplished. In the modeling of shallower features the contribution of deep structure to the observed gravity must be removed. Development of regional models allows the quantification of this contribution and its later removal by digital methods. Typically these regional gradients can be approximated in the model by a series of line segments $(y=m x+b)$ which are either added or subtracted as needed. 3) An isolation of local anomalies is desired. Ideally this means that if one removed from the observed gravity profile contributions made by the regional gradient and regional model, then only local anomalies would remain. In practice the regional model is developed so that calculated gravity values match as closely as possible observed gravity values, with the noted exception of the local line. This places the local line in a proper geologic and gravitational framework so that it may be modeled in detail

\section{Construction}

The construction of a regional model is initiated by the completion of a regional gravity profile. A regional profile is generated by extending the local line approximately $100 \mathrm{~km}$ at each of its ends and then migrating onto it appropriately selected regional gravity measurements. These measurements were aquired from several sources including previous gravity studies, published 
gravity maps of Oregon and Washington and a northwest gravity data base compiled by the United States Geological Survey. The majority of regional gravity values used in this study were obtained from this data base.

The FORTRAN program PRINBEST was developed to search a "window" of the regional data base by establishing cutoff values based on latitude and longitude. PRINBEST allows the user to place this window in any map orientation and to designate any window width, thereby providing complete control over which data points are selected.

The FORTRAN programs LOCAL and REGIONAL were developed to prepare the existing local and selected regional stations for the FORTRAN gravity modeling program FREEAIR (Talwani and others, 1969). LOCAL treats detailed line data and REGIONAL utilizes output from PRINBEST to calculate a migrated horizontal distance (along the regional 1 ine), a projected distance (the distance a station must be migrated) and an elevation in kilometers above sea level for each station. It is imperative that stations be selected which, to the greatest degree possible, satisfy the requirement of geologic homogeniety. The number of stations ultimately considered is a primary function of the size of the search window in PRINBEST. Listings of PRINBEST, LOCAL, REGIONAL and FREEAIR can be found in Appendix A.

To preserve the significance of a gravity measurement its station elevation must be migrated in conjunction with 
its gravity value. As a result, regional elevation and gravity profiles are to a certain extent considered "manufactured".

Completed regional Free Air gravity profiles for the Interstate and Fourth Plains lines are shown in Figures 5 and 6. Stations were chosen to provide as complete a coverage as possible while adhering to the criteria for their selection. The overall trend of both profiles is quite similar indicating their major lithospheric characteristics do not differ appreciably. Discrepencies that do exist might be due to the difference in orientation of the two lines. The Interstate line trends east - west while the Fourth Plains line trends approximately N 57 E. This means they intersect crustal components at different angles, changing their gravity profile response over unit boundaries. The location of the two profiles with respect to regional Bouguer gravity variations can be seen in Figure 7. These profiles formed the basis for the construction of the regional Free Air gravity models shown in Figures 8 and 9 . While several methods might have been be used to generate these regional models the following was employed in this study.

Initially, the best approximation to the known geology was introduced into the model. This was done by building lithologic columns using known locations, depths and densities from the surface to a depth of $-6.0 \mathrm{~km}$. 


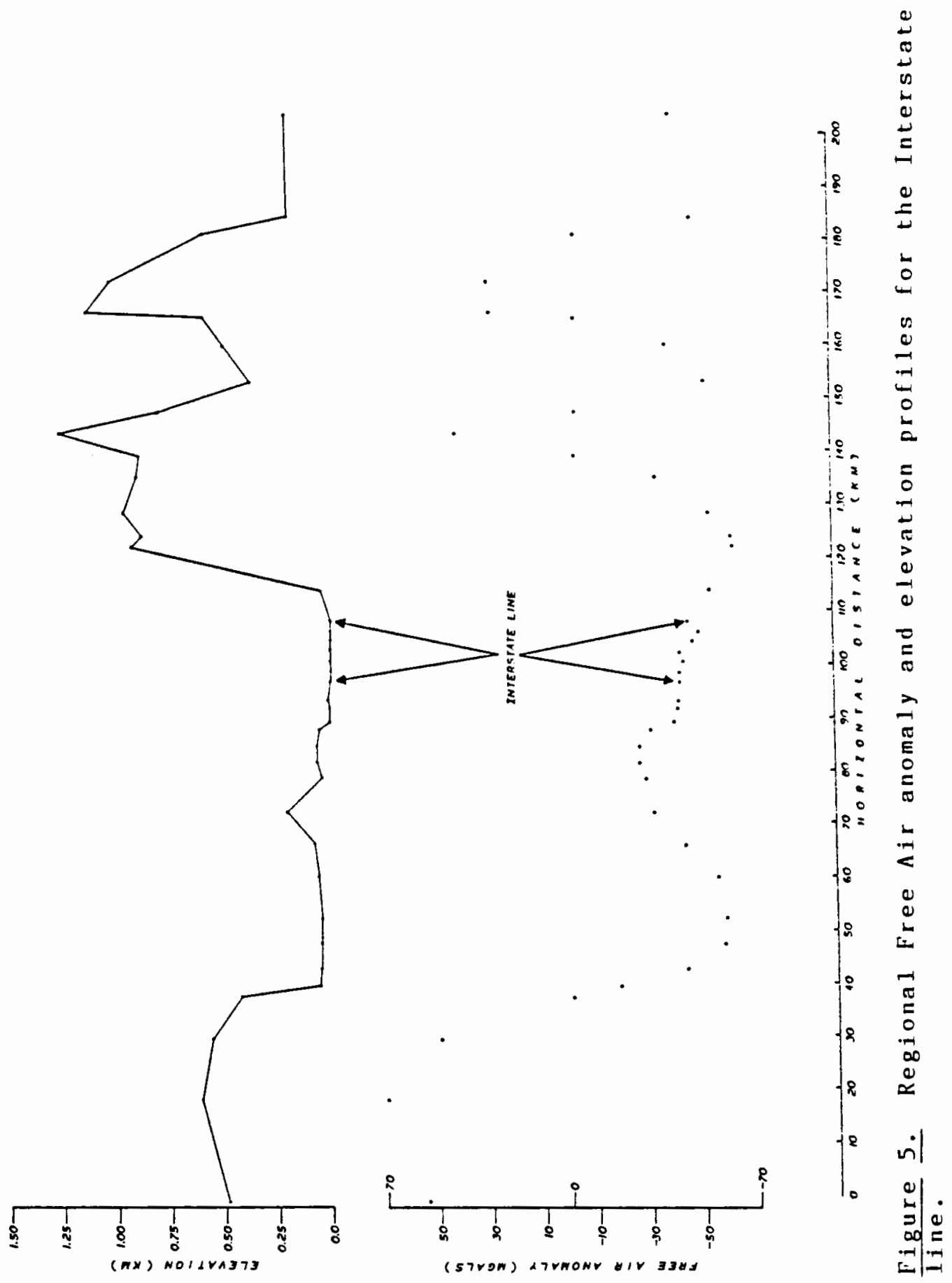




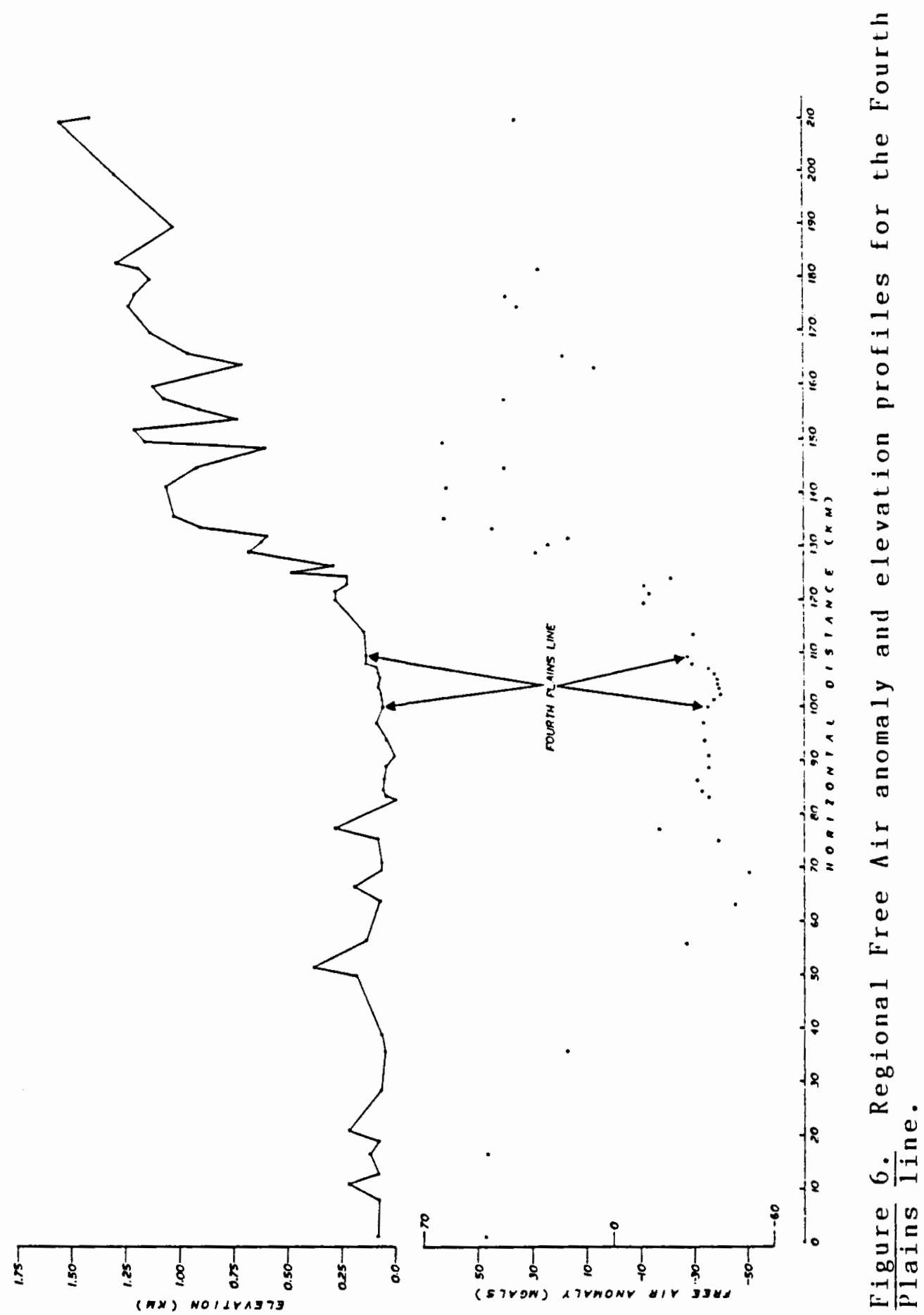




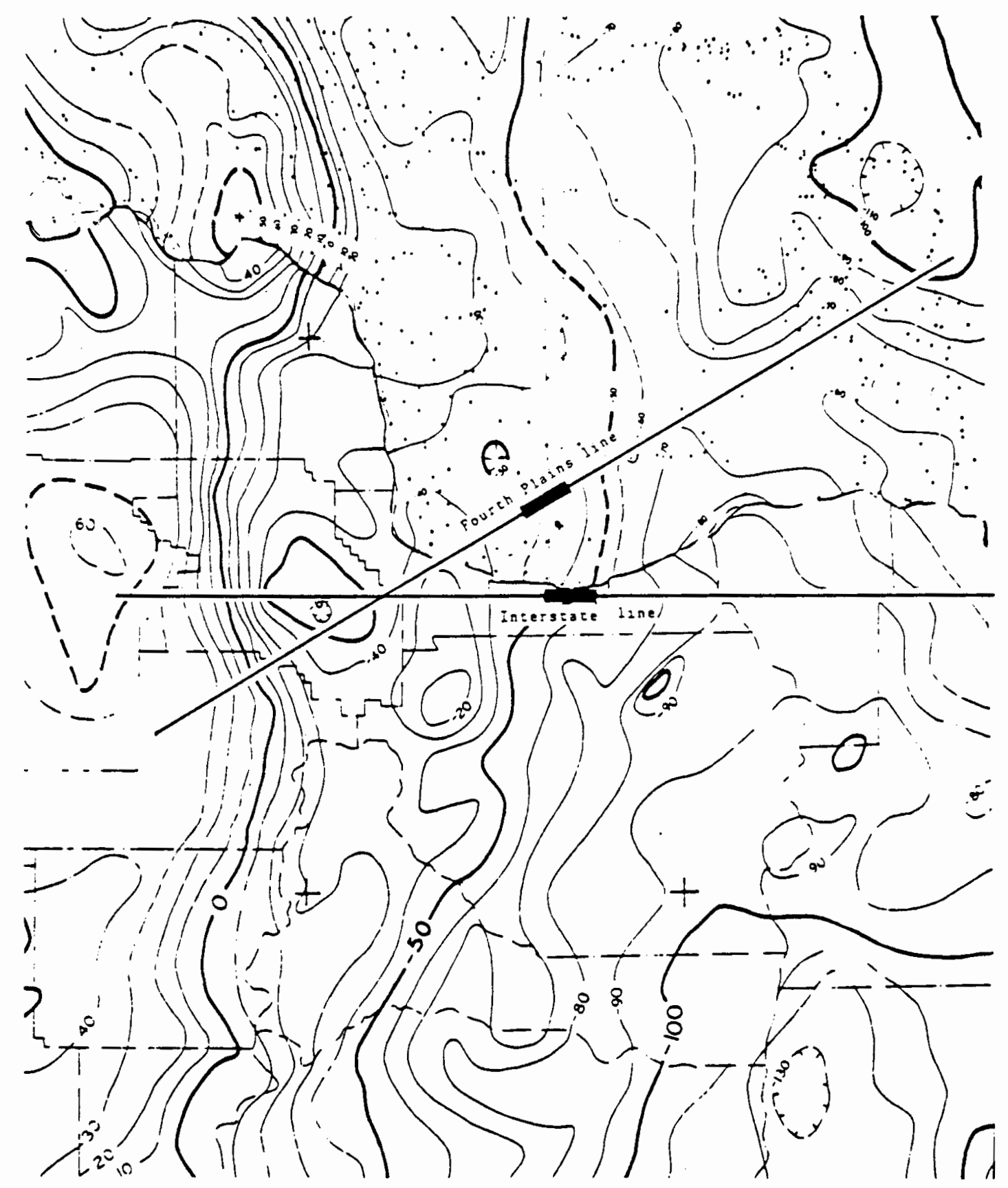

Figure 7. Location of gravity lines with respect to regional Bouguer gravity (after Thiruvathukal and Berg, 1967). 
45

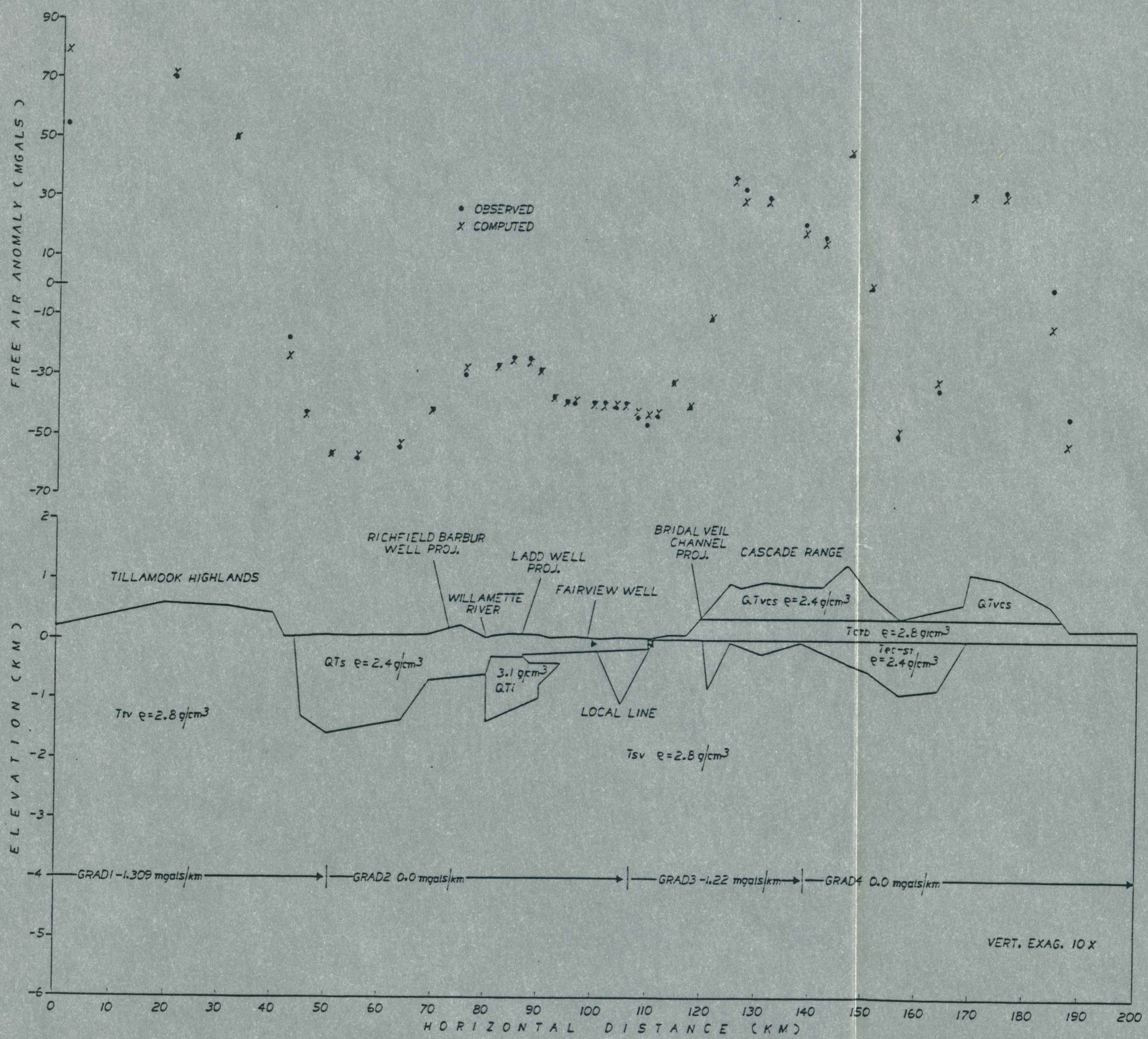

Figure 8. Observed and computed regional Free Air gravity anomaly profiles and regional Free Air gravity model for the Interstate line. 


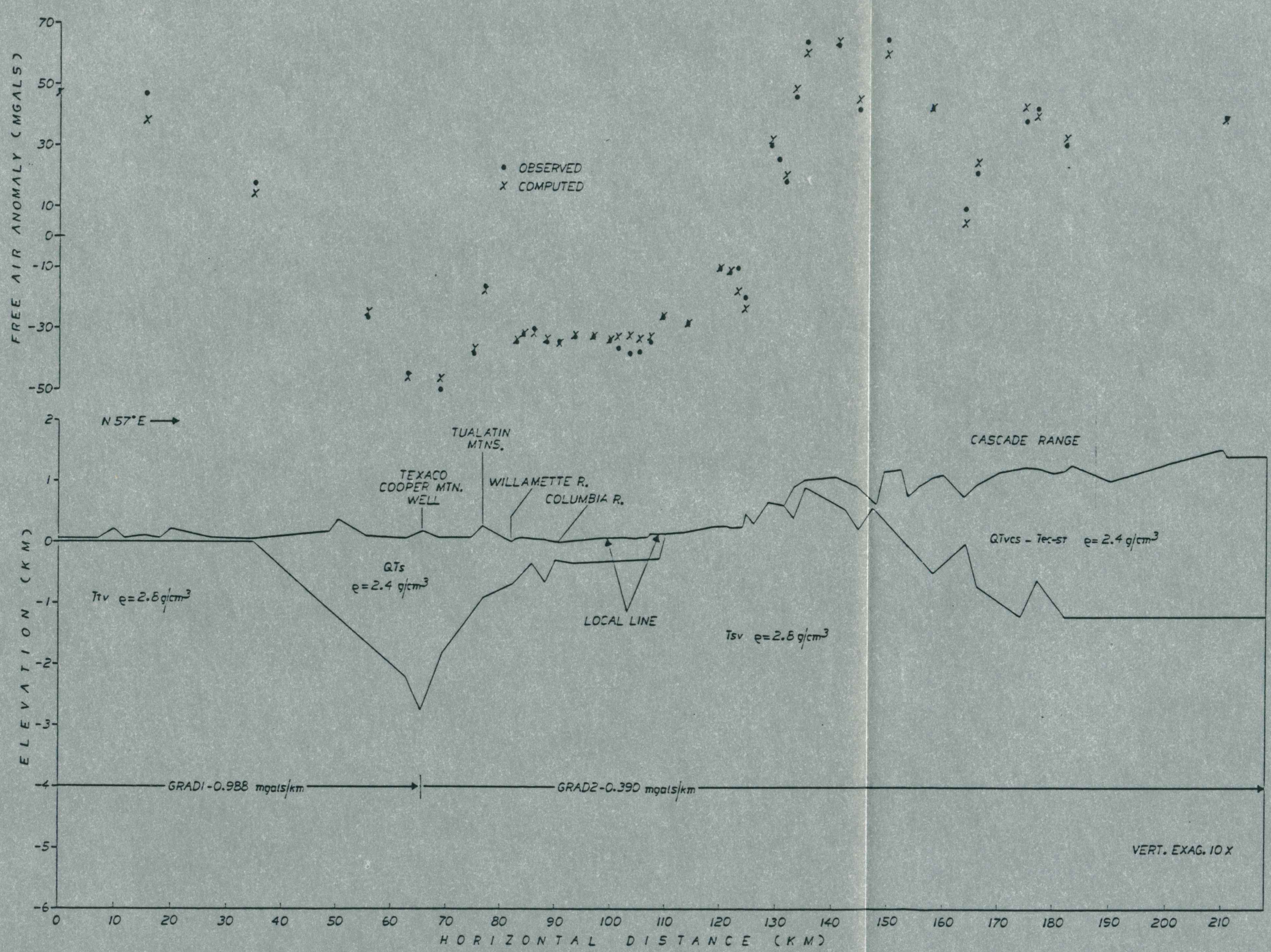

Figure 9. Observed and computed regional Free Air gravity anomaly profile and regional Free Air gravity model for the Fourth Plains line. 
Because they represent the geology at only one location these columns are assumed to have a limited horizontal extent. A gravitational contribution was found for each unit in a column based on its thickness and density utilizing an infinite slab approximation. The summation of these unit contributions yielded a total gravitational effect for each column. The resulting calculated gravities approximated values which would be generated at these column locations by the program FREEAIR in a completed gravity model. At this point regional gradients could be determined.

If one assumes that the observed gravity at a column location is composed of effects caused both by mass distributions in the selected lithologic column and remaining mass distributions in the lithosphere below -6.0 $\mathrm{km}$, then by calculating a total column gravity we have already determined that portion of the observed gravity dependent only on shallow structure. The portion that remains can be considered the regional gradient which is primarily a function of the behavior of the Mohorovic discontinuity and to a lesser extent the proximity of large density contrast units which are not represented in the model. The value of this gradient was determined and removed as described below.

The determined total column gravities were subtracted from their corresponding observed gravity values because contained within the observed values are contributions of 
the regional gradient. The remainder represented contributions of material and structure below $-6.0 \mathrm{~km}$ and when integrated with other column remainders over distances of tens of kilometers constituted a regional gradient. After inspection of the gradient segments between columns it was determined that a single gradient could not accurately depict regional changes in either model and a series of shorter gradients were applied. As can be seen in Figures 8 and 9 the Fourth Plains line required two gradients while the Interstate line required a total of four. To compensate for the occurrence of these gradients within the observed gravity profiles, appropriate gradients were removed from both calculated profiles. In each case these were applied in a cumulative manner by FREEAIR which was modified to accept additional gradients.

The gradients of both models are eastward decreasing, possibly reflecting displacement of mantle by an increasingly thick lithosphere (Thiruvathukal, 1970). Gradient segments were always negative or zero with a maximum value of -1.309 mgals reached in the Interstate line.

Since gradients represent line function corrections over great distances they can not, on a station to station basis, account for small scale changes in gravity values. These variations are "modeled" by extending stratigraphic units between columns to form blocks. The shape, 
orientation and configuration of these blocks were first approximated using manual methods and then finalized by adjustments made with FREEAIR.

\section{Completed Models}

Maximum gravity values are found in the Coast and Cascade Ranges while minimums correspond to the Tualatin and Portland Basins respectively. The Interstate line diplays a total maximum to minimum gravity fluctuation of approximately $120.0 \mathrm{mgals}$ while the Fourth Plains line variation is somewhat less at approximately 100.0 mgals. This difference is likely again due to the angle at which these lines intersect crustal components and also the extent to which they encounter lithologic types common to both. Calculated values in the vicinity $( \pm 20-30 \mathrm{~km})$ of a local line agree with observed gravity values to within approximately $\pm 1.0 \mathrm{mgals}$, while at model edges these values reached $\pm 15.0 \mathrm{mgals}$ in some cases. Modeling was not extended below $-6.0 \mathrm{~km}$ since the composition and physical characteristics of materials at this depth become increasingly uncertain. In both models the majority of significant features occurred at depths less than $-2.0 \mathrm{~km}$. Because of these factors a homogenous density was chosen for the material between $-2.0 \mathrm{~km}$ and $-6.0 \mathrm{~km}$ effectively generating a constant gravity response which is somewhat arbitrary in nature. Differences in deep structure not addressed in the model itself are better and more 
completely compensated for during the removal of regional gradients.

In general, both models are broadly comparable containing modeling blocks that are similar in density, shape and location. It is advantageous to keep regional models as simple as possible and therefore the combination or omission of some modeling units is possible. An example is the notable absence of the Tcrb (Columbia River Basalt Group) west of the Willamette River in the Interstate regional line. It was omitted here since unlike east of the river where it was easily included within the Skamania volcanics, its westward extension would have proven complex without including any essential information to either the local or regional models. Indeed, the gravitational contribution of the Tcrb in this half of the model was minimal and better approximated by a depth adjustment of the QTs (sediment) - Ttv (Tillamook volcanic) interface. One significant difference between the models is the inclusion of a QTi (intrusive) block in the Interstate line which is required to avoid a pronounced gravity deficit. This feature seems restricted to the southern half of the Portland Basin where it was also modeled by Perttu (1980) as a possible QTvcs (Boring chemical type) intrusive. While broad conclusions might be drawn from these models, any interpretation based on them concerning regional geologic relationships should remain supposition. Only in the immediate area of the local line where better 
geologic control exists can any interpretation enjoy reasonable certainty. The emphasis in this study is therefore directed towards the evaluation of local models. 
COMPLETED LOCAL MODELS

INTERSTATE LOCAL MODEL

Gravity Profile

The Interstate local gravity profile appears as Figure 10. This figure shows both the original and terrain-corrected Free Air data, the value of the terrain correction and the elevation profile. The 1.5 mgal feature at km 100.0-101.5 can be partially attributed to increased elevation. In the remainder of the profile, however, elevation fluctuations do not contribute appreciably to the Free Air Anomaly trend. Significantly, from km 104.25111.0 elevation remains unchanged while the gravity profile displays relatively large fluctuations. This divergent relationship strongly indicates that units with

considerable lateral density contrast exist within the shallow subsurface section.

Figure 11 shows the trend of the calculated regional profile from Figure 8 and the observed profile for the local line. These trends can be used to determine the shape, location and to a lesser extent the magnitude of anomalies indicated by preliminary examination of the elevation and gravity profiles. The calculated regional profile, when compared with the local observed profile shows comparatively little short wavelength, less than 3 


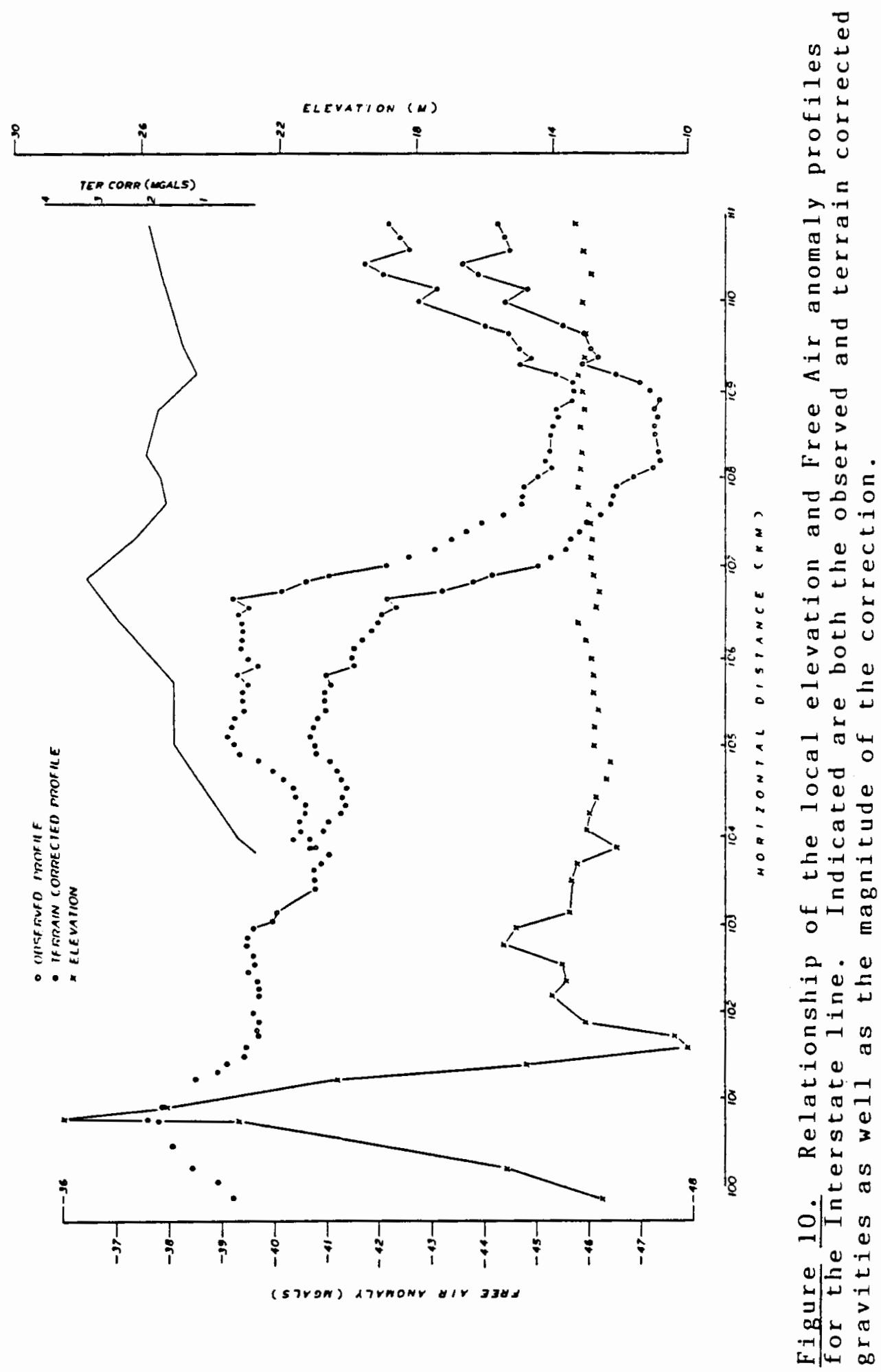




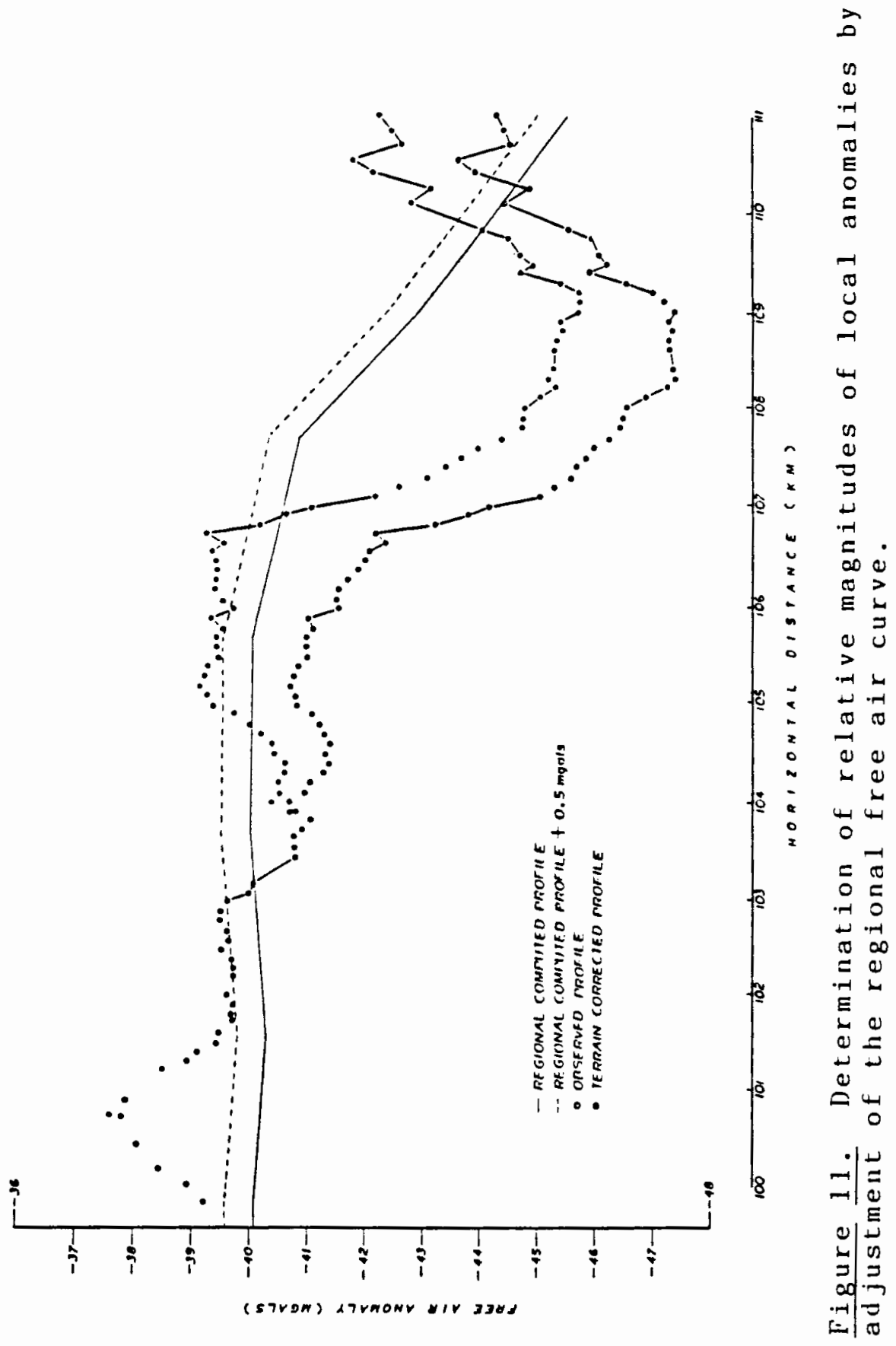


$k m$, amplitude variation. By means of this comparison the irregularities in the observed profile at km 100.0-101.5, $\mathrm{km} \mathrm{102.75-105.25} \mathrm{and} \mathrm{km} \mathrm{107.0-111.0} \mathrm{can} \mathrm{be} \mathrm{considered}$ shallow structure anomalies. Approximate anomaly amplitudes can be determined if a $0.5 \mathrm{mgals}$ constant is added to the entire regional profile thereby providing a base gravity curve to which small scale variations in the local profile can be compared. This procedure is largely judgemental in nature and is later eliminated by final adjustments made during local modeling. It is based on the observed behavior of the calculated profile and on suspected geologic relationships. It results in the fixing of anomaly amplitudes which are related to each other through a common base gravity curve. The base curve for this profile lies between $-39.0 \mathrm{mgals}$ and $-40.0 \mathrm{mgals}$ for the initial $7.0 \mathrm{~km}$ of the model and decreases systematically thereafter. By this method three major anomalies are distinguished here, corresponding to approximate values of $+1.75 \mathrm{mgals}$ at $\mathrm{km} \mathrm{100.0-101.5,-1.5}$ mgals at $\mathrm{km} \mathrm{102.75-105.25} \mathrm{and}-4.0 \mathrm{mgals}$ at $\mathrm{km} \mathrm{107.0-111.0.}$ Having established these anomalies we can now make preliminary evaluations of the parameters of the density contrasts which caused them. To accomplish this, simplistic models are designed whose calculated gravity profiles simulate the corresponding observed profiles. Once a match is found, the dimensions of the models place 
reasonable limits on the parameters of the anomaly producing bodies. This method will be illustrated here by a single example.

\section{Limits of Shape, Depth And Density Contrast}

The following discussion utilizes a number of assumptions and derivations which can not be covered here. The reader is directed to complete treatments of gravity techniques as they apply to thin horizontal sheets and fault approximations which appear in Telford (1976).

An established premise of gravity investigation provides that when using the maximum density contrast allowed by geologic conditions, the maximum depth for a given anomaly producing body or (APB) is closely approximated by the depth to a vertical sided mass (prism or cylinder) whose calculated anomaly provides the best solution (match) to the observed anomaly (Skeels, 1963). Since the available geologic and geophysical data indicates that strike-slip faulting with an appreciable dip-slip component are associated with similar anomalies in the Portland Basin (Beeson and others, 1976), we are led to the following assignments and assumptions:

1) The $-4.0 \mathrm{mgal}$ anomaly at $\mathrm{km} 107.0-111.0$ and a probable source structure can be generalized as in Figure 12.

2) The shape of the anomaly indicates a down-faulted APB (prismatic and graben-like) with bounding fault planes dipping near 90 degrees, where $t$ is the thickness and $w$ is 


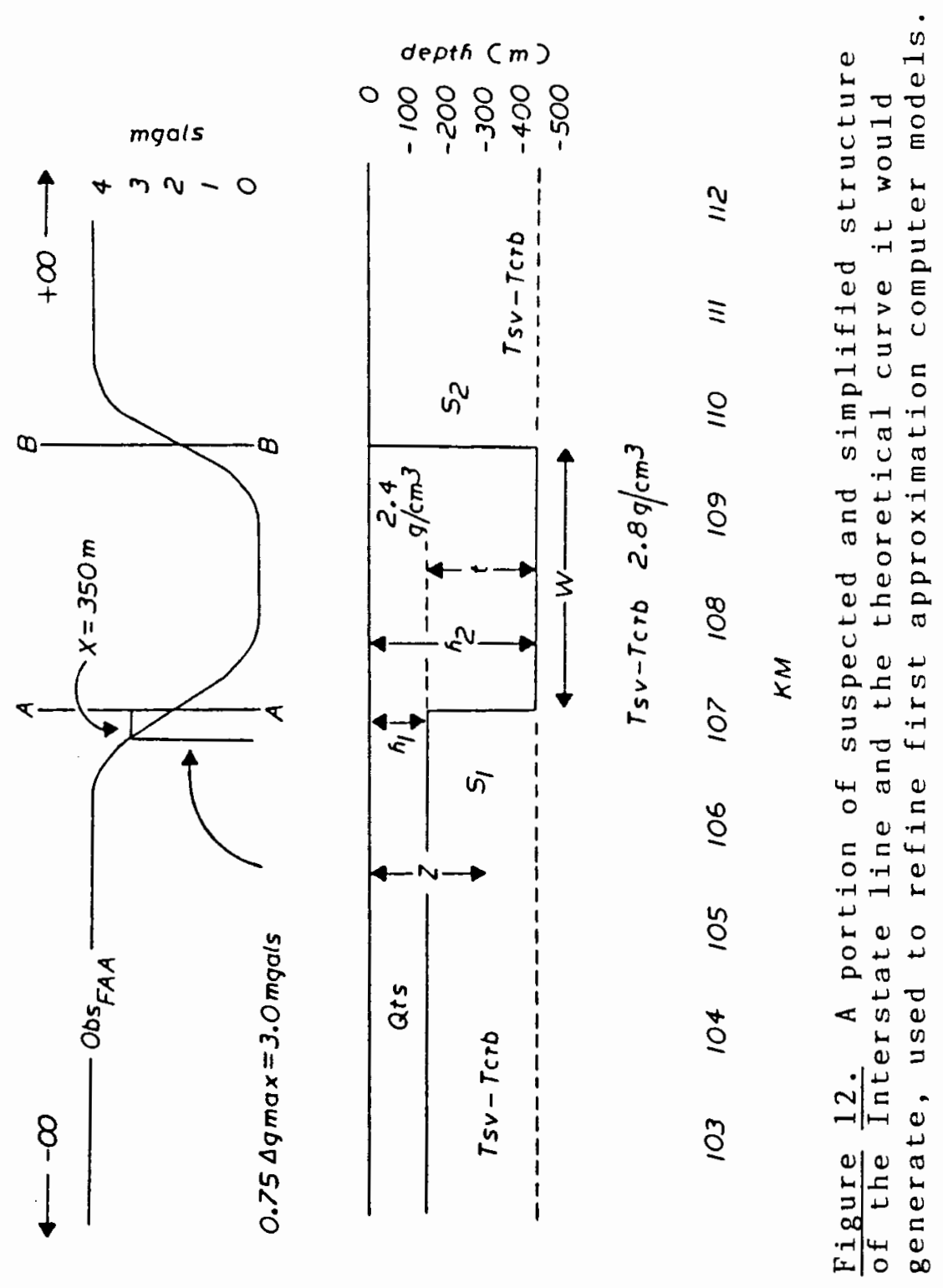


the width of the prism.

3) The faulted $A P B$ has a density contrast of $-0.4 \mathrm{~g} / \mathrm{cm}^{3}$ which arises from an assumed juxtaposition of $2.8 \mathrm{~g} / \mathrm{cm}^{3}$ volcanic and $2.4 \mathrm{~g} / \mathrm{cm}^{3}$ sedimentary rocks.

4) The Tsv-Tcrb and QTs units in the vicinity of $\mathrm{S}_{1}$ (slab 1) are of constant thickness, are horizontally continuous and display no density variance. They provide a constant background gravity and therefore $S_{1}$ can be assumed to represent a half infinite slab.

A relationship which describes vertically faulted strata is given by Telford (1976). Radian measure applies

$$
\Delta g=4 \operatorname{ret}\left(\tan ^{-1}\left(h_{2} / h_{1}\right)^{1 / 2}-\tan ^{-1}\left(\hbar_{1} / h_{2}\right)^{1 / 2}\right)
$$

where $\Delta \mathrm{g}$ is the maximum gravity value for the anomaly measured in gals, $\gamma$ is the universal gravitational constant, $\rho$ is the density contrast, $t$ is thickness of the $A P B$ in centimeters and the depths to top and bottom of the $A P B$ are given by $h_{1}$ and $h_{2}$.

From (6) it should be possible to determine a minimum thickness without prior knowlege of $h_{1}$ or $h_{2}$. Examining (6) we can see that if the ratio $h_{2} / h_{1}$ (fault displacement) becomes very large then $\operatorname{TAN}^{-1}\left(h_{2} / h_{1}\right)^{\frac{1}{2}}$ approaches $\pi / 2$ and $\operatorname{TAN}^{-1}\left(h_{1} / h_{2}\right)^{\frac{1}{2}}$ approaches zero. Rearranging (6) we have

$$
t=\Delta g\left(4 \operatorname{re}\left(\tan ^{-1}\left(\hbar_{2} / \hbar_{1}\right)^{1 / 2}-\tan ^{-1}\left(\hbar_{1} / \hbar_{2}\right)^{1 / 2}\right)\right)^{-1}
$$

where the quantity $\Delta g$ max (Figure 12) occurs at $x \rightarrow-\infty$. 
Let us assume that the ratio $h_{2} / h_{1}$ becomes exceedingly large enabling $-\mathrm{TAN}^{-1}\left(\mathrm{~h}_{1} / \mathrm{h}_{2}\right)^{\frac{3}{2}}$ to be neglected. It is not suggested here that the $A P B$ is faulted infinitely deep, but rather that such an assumption means ( $6 a$ ) can be rendered to a form which will yield $t$, a minimum thickness. Substituting $\pi / 2$ for $\operatorname{TAN}^{-1}\left(\mathrm{~h}_{2} / \mathrm{h}_{1}\right)^{\frac{1}{2}}$, utilizing a density contrast of $0.4 \mathrm{~g} / \mathrm{cm}^{3}$ and neglecting $-\mathrm{TAN}^{-1}\left(\mathrm{~h}_{1} / \mathrm{h}_{2}\right)^{\frac{1}{2}}$ we can evaluate (6a) to yield a minimum APB thickness of $238.61 \mathrm{~m}$. Obviously, fault displacement can not approach infinity and the calculated thickness is decreased somewhat by $-\mathrm{TAN}^{-1}\left(\mathrm{~h}_{1}\right.$ $\left./ h_{2}\right)^{\frac{1}{2}}$. It is the nature of (6), however, that $-\mathrm{TAN}^{-1}\left(\mathrm{~h}_{1} / \mathrm{h}_{2}\right.$ )$^{\frac{1}{2}}$ diminishes rapidly allowing the derived thickness to closely approximate the true APB thickness.

If $\mathrm{S}_{1}$ can be considered a half infinite slab, then by similar reasoning, so can $\mathrm{S}_{2}$. The anomaly that they jointly cause (Figure 13) can be separated into its component parts. That portion caused by $S_{1}$ is shown in Figure 13 as an idealized representation of the relationship between the calculated gravity profile and the geometry of the half infinite slab. An approximation of the depth to the center of $S_{l}$ can be derived from the relationship given by Dobrin (1976) for a half infinite slab; radian measure applies

$$
g_{z}=2 \operatorname{ret}\left(\pi / 2-\tan ^{-1} \frac{x}{z}\right)
$$

where $g_{z}$ is the gravity in gals at some distance $x, z$ is 


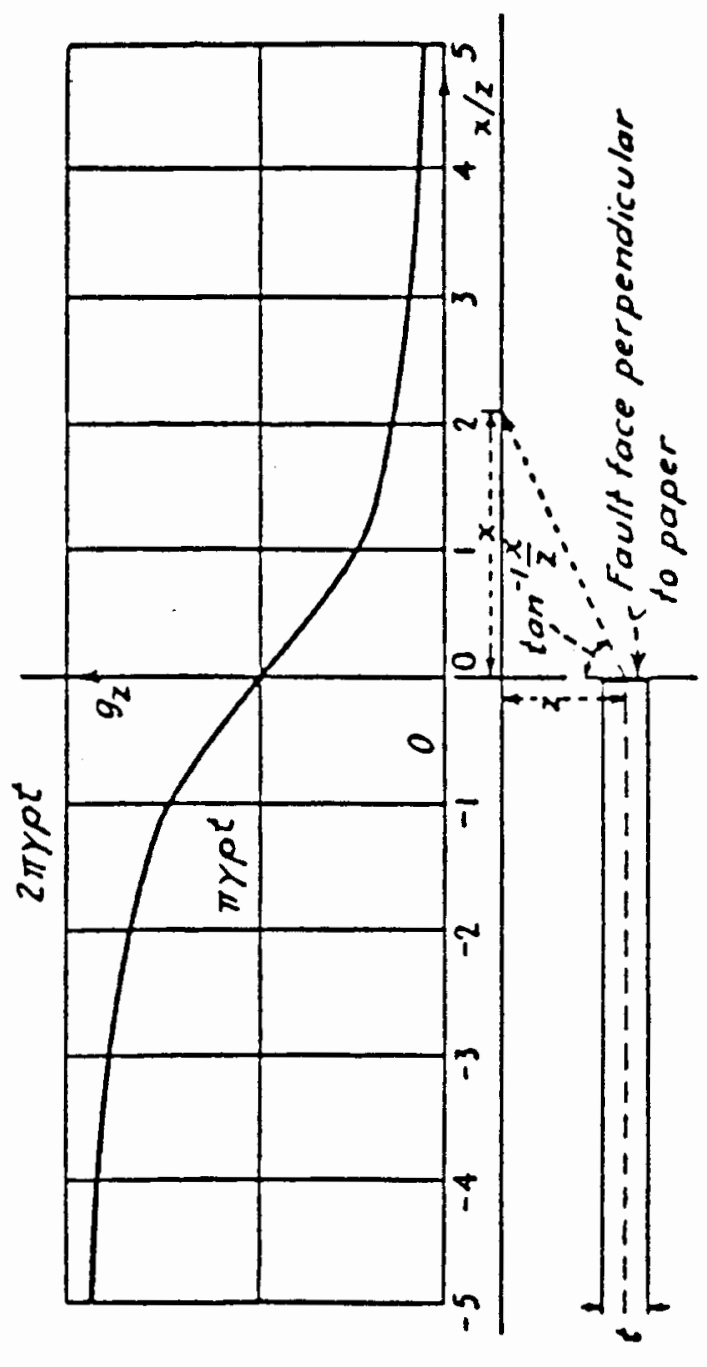

$\stackrel{0}{\Perp}$

당

- $\rightarrow$

$0 \frac{1}{3}$

$\stackrel{-1}{=} 0$.

$\rightarrow$ us

400

- $\rightarrow-1$

0

$\rightarrow$ 대 $\Rightarrow$

$\sigma \pm \downarrow$

ᄃ 0

$\sigma \pm \cdot \pi$

$>c$

○. 매

व

$\perp 0$

$\nabla 0$

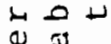

U

$\rightarrow 5$

() ठ क

虽山

上 0

U N U

0 is

$>0$.

$\Rightarrow 50$

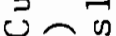

5

i. $1 .-1$

m|山

0 工

0|

$\exists=\sqrt{3}=1$

压 $1 \times 0$ 
the depth to the center of $S_{1}$ and $\rho$ is the density contrast. Rearranging ( 7 ) we obtain an expression for the ratio $x / z$ given by

$$
\frac{x}{z}=\tan \left(\frac{g_{z}}{2 \gamma \rho t}+\pi / 2\right)
$$

Note that the relationship between $g_{z}$ and $x$ are fixed by curve shape and all other variables remain fixed by prior assumption. The depth $z$ can be found by the substitution of a value $x$ and its corresponding $g_{z}$ value. From Figure 12, selecting the distance $350.0 \mathrm{~m}$ at $0.75 \Delta \mathrm{g} \max$, evaluation of ( $7 \mathrm{a}$ ) yields the value $-349.89 \mathrm{~m}$ as $z$, the depth to the center of $S$. By the addition and subtraction of 0.5 to $z$, the calculated values $h_{1}=-230.58 \mathrm{~m}$ and $h_{2}=$ $-469.19 \mathrm{~m}$ can be found.

Upon the comparison of Figures 12 and 13 , and assuming that the ordinate at $A$ (Figure 12) represents the location in the observed profile that corresponds to the fault plane which defines $S_{1}$, then the ordinate at $B$ (Figure 12) must also define a similar fault plane bounding $\mathrm{S}_{2}$. The horizontal distance between these ordinates fixes a corresponding width between the fault planes which terminate the APB. The approximate width w of the APB is therefore $2740.0 \mathrm{~m}$.

In summation, the above treatments indicate the following. The observed $-4.0 \mathrm{mgal}$ anomaly at $\mathrm{km} 107.0-$ 111.0 delineates a prismatic body. This APB diplays 
appreciable thickness, the value of which is partially dependent on $\rho$ its density contrast. The quantitative evaluation of (6) and (7) yields the approximations shown in Table 3 .

TABLE III

PARAMETERS FOR ANOMALY AT KM 107.0-111.0 - INTERSTATE LINE

(I) $t$ - the APB (prism) thickness238.61

(II) $z$ - depth to center of APB$-349.89$

(III) $h_{I}$ - depth to top of APB$-230.58$

(IV) $h_{2}$ - depth to bottom of APB$-469.19$

(V) width of $\mathrm{APB}-$ 2740.0

As the preceding example indicates, the manual construction of detailed models quickly becomes complex and exhaustive, therefore these parameters and similarly determined values for other anomalies in the study were used as guidelines for computer generated models.

Completed Detailed Model

The completed Interstate local model and its associated observed and computed Free Air curves are shown in Figure 14. The observed curve is represented by a solid line for visual clarity, however this does not imply a continuous knowledge of the observed gravity behavior. 

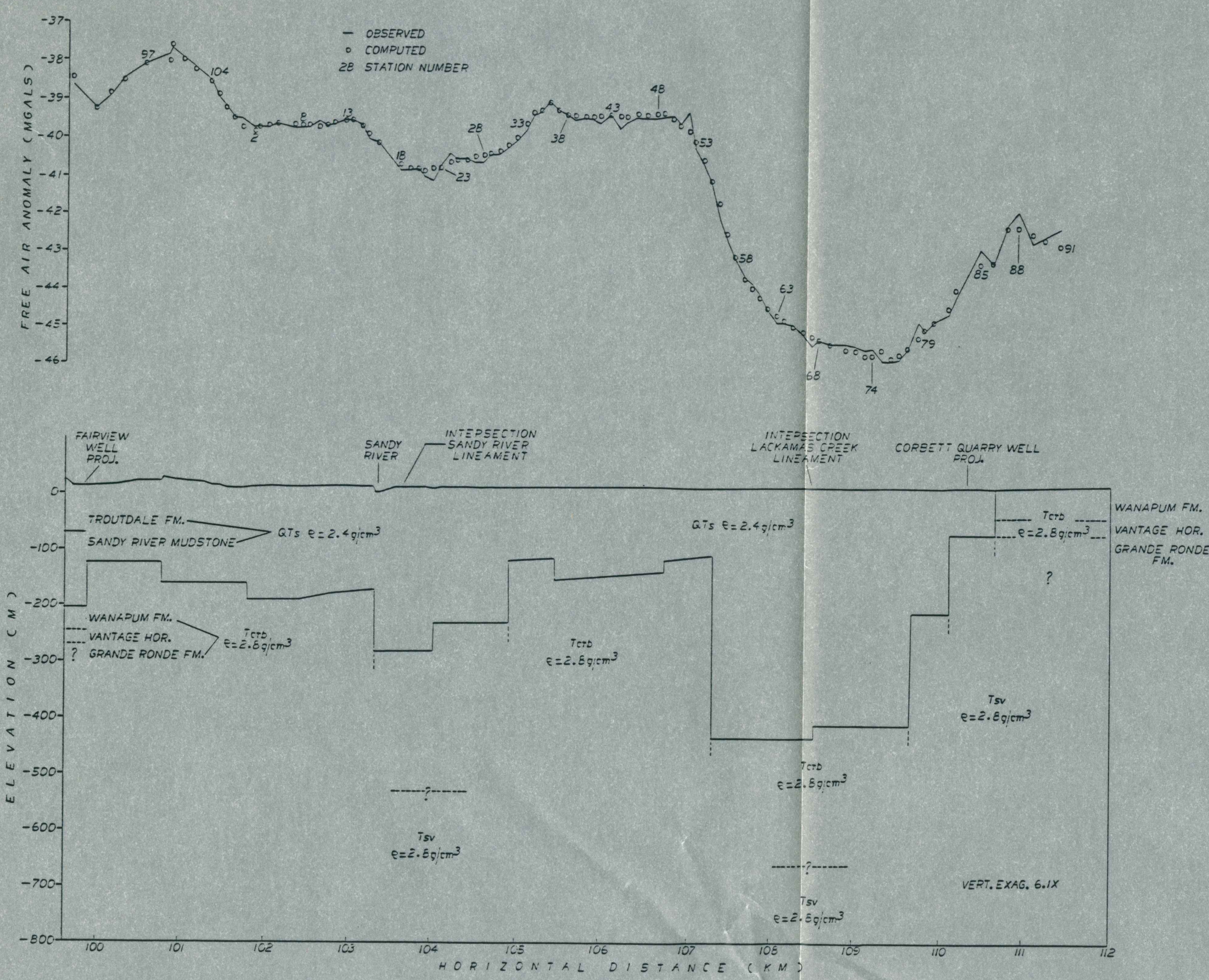

Figure 14. Observed and computed local Free Air anomaly profiles and completed local model of the Interstate line. 
Locations where specific values for the observed curve are known coincide on a vertical axis with the locations of computed stations. Total gravity fluctuation for the line is nearly 8 mgals with a high gravity value of -37.8 mgals at $\mathrm{km} 101$ and a low gravity value of -45.6 occurring at $\mathrm{km}$ 109. This fluctuation is distributed over at least three anomalies and most 1 ikely indicates a gravity response to several smaller structures. Agreement between the observed and computed curves ranges from coincidence to $\pm 0.45 \mathrm{mgals}$ with a mean value of $0.016 \mathrm{mga} 1 \mathrm{~s}$. Quantitatively the match is reasonable. Approximately 38 percent of the calculated stations indicate a numerical match value with the observed curve less than the previously determined maximum reasonable measurement error of $0.06 \mathrm{mgals}$.

Portions of the geology of two nearby wells was selectively projected into the local line. The Corbett Quarry well which is hosted entirely within Columbia River basalt has been projected north to the local line approximately $50 \mathrm{~m}$. This well provides control for the model in the area of $\mathrm{km} \mathrm{112.} \mathrm{Preliminary} \mathrm{stratigraphy} \mathrm{for}$ this well was determined by Tolan and Beeson (pers. comm., 1986 ) with the aid of $x$-ray flourecence chemical analysis performed by Hooper (WSU, 1986). The Fairview well was projected north to the local line approximately $0.5 \mathrm{~km}$. The portion of this well below $-200.0 \mathrm{~m}$ has been interpreted by Perttu (1980) to represent a Columbia River 
basalt section which overlies late Eocene to Oligocene sediments which in turn overlie Skamania strata. This interval in the Fairview well is reinterpreted here based on the chemical analysis of the Corbett Quarry well and several other more recent wells (Tolan and Beeson unpublished data, 1986). Because of area-wide similarities, this data indicates that the basalt penetrated in the Fairview well belongs to the Miocene Wanapum Formation and the sediments encountered are actually the Miocene hiatus locally identified as the Vantage horizon. Basalts below this horizon (Perttu's Skamania) are of the Grande Ronde chemical type. It should be noted that strata below the Vantage horizon was not drilled by the Fairview well and its lithologic interpretation is hypothetical. Unfortunately no chemistry is available for the Fairview well.

0n1y two modeling units are required to provide a solution to the observed gravity curve. Because individual formations within the model are only locally differentiated and since gravity can not distinguish between units with similar densities; it was necessary to combine formations based on their major lithology. The overburden sedimentary unit represents the combined occurrence of the Troutdale Formation and the Sandy River Mudstone (QTs) while basement strata is composed of Columbia River basalt and Skamania volcanics (Tcrb-Tsv). A density contrast of $0.4 \mathrm{~g} / \mathrm{cm}^{3}$ is utilized assuming the 
juxtaposition of these two lithologies. Such a relationship is suggested by the pronounced vertical character of portions of the Qts-Tcrb interface boundary as required by the model. Magnitudes of these vertical segments range from approximately $25 \mathrm{~m}(82 \mathrm{ft}$ ) to $325 \mathrm{~m}$ $(1066 \mathrm{ft})$.

Even though several smaller boundaries correspond to anomalies many orders of magnitude greater than the maximum attributable error, they are suspect because they are represented at most by only three stations within the line. It is not clear whether they are caused by aberations within the data or indeed by small scale structure. Had spacing been greater, it is possible these smaller features might not have been delineated.

The model represents the simplest combination of structure and stratigraphy which enables a good match between the observed and computed profiles. Significantly, any divergence from the vertical character of the unit boundaries quickly causes the computed profile to flatten. This flattening then requires the introduction into the model of small localized high and low density contrast bodies for which there is no geologic precedent.

Previously determined parameters for the $A P B$ at $\mathrm{km}$ 107.0-11l.0 are comparable with those found in the model. A prismatic structure is indicated at this location with parameters as contrasted with those in Table III: $w=3000$ 
$\mathrm{m}, \mathrm{t}=300 \mathrm{~m}, \mathrm{z}=-300 \mathrm{~m}, \mathrm{z}_{1}=-150 \mathrm{~m}$ and $\mathrm{h}_{2}=-425 \mathrm{~m}$.

The most striking features of the Interstate local model are the corresponding locations of the Sandy River and Lackamas Creek lineaments with both major anomalies and therefore structures traversed by the local line. Due in part to probable erosion of the Columbia River and concealment by recent alluvium, the measured 1 ine does not cross either 1 ineament in an area where it is expressed topographically. However, negative anomalies and their causative structures occur precisely at the intersections of the local line with the projections of both lineaments.

FOURTH PLAINS LOCAL MODEL

\section{Gravity Profile}

The Fourth Plains local gravity profile appears in Figure 15. The figure shows the trend of the observed Free Air curve and its associated elevation profile. That portion of the observed curve between $\mathrm{km} 105.5$ and $\mathrm{km}$ 109.25 shows a direct correlation with elevation. This correlation is so prominent as to preclude the detection of any anomalies present in this interval based on the profile alone. The initial 2 kilometers of the profile from $\mathrm{km}$ 99.5-101.5 indicates great divergence. The large deviation betweeen the behavior of the elevation and Free Air profiles is indicative of the occurrence of a sharp lateral density contrast boundary in the shallow subsurface section. 


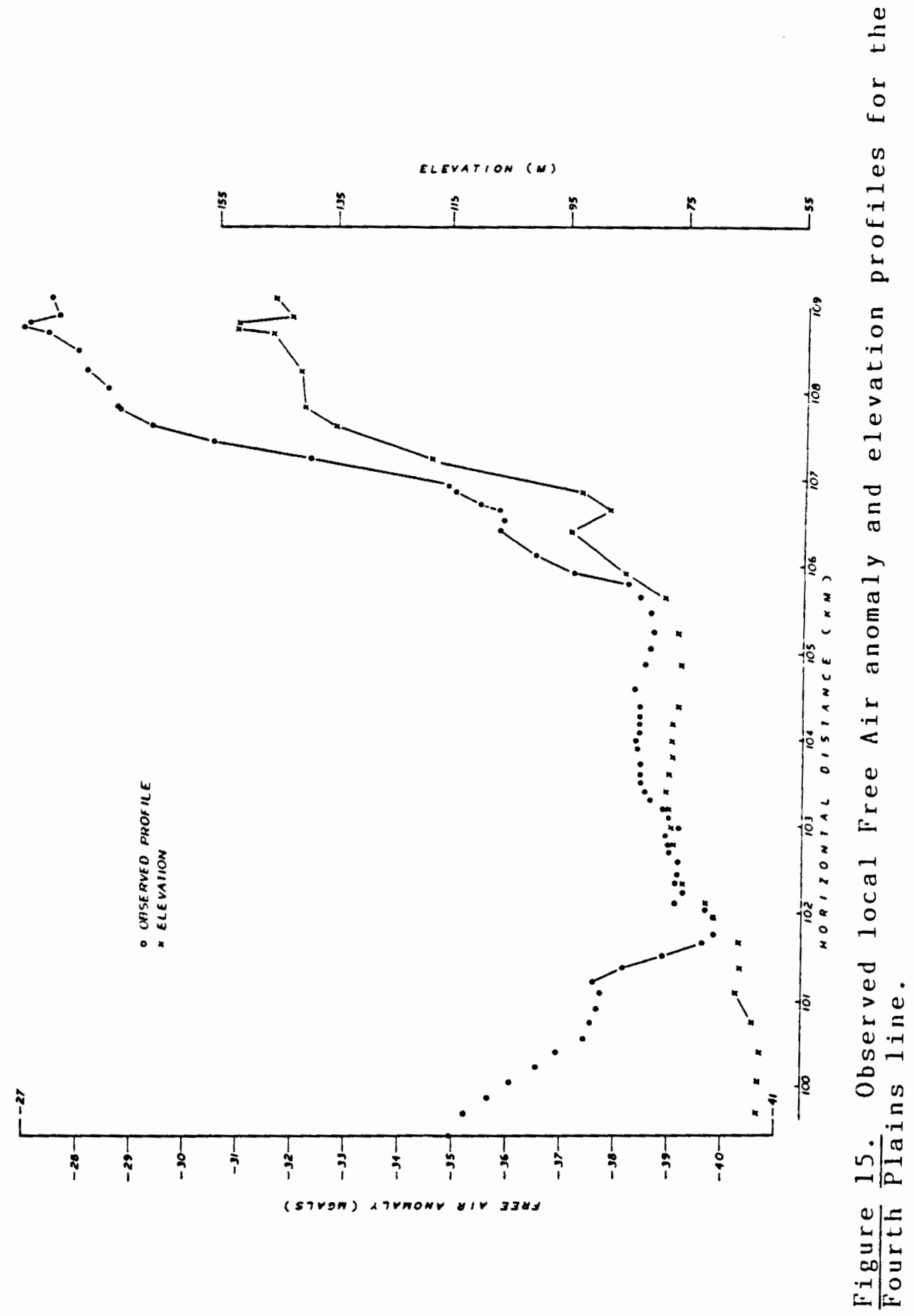


Figure 16 shows the trend of the calculated regional profile from Figure 9 and the observed profile for the local line. The calculated regional curve displays a near constant value of $-33.5 \mathrm{mgals}$ for the first $7 \mathrm{~km}$ of the line. At $\mathrm{km} 106.8$ it increases sharply to meet the observed curve thus defining a negative gravity region nearly $7 \mathrm{~km}$ in width. The left side boundary of this region is poorly defined since the observed curve is still increasing here. Extrapolation of this increase by means of the addition of regional observed stations allows a levelling at approximately $-33.75 \mathrm{mgals}$ near $\mathrm{km} \mathrm{98.25.} \mathrm{The}$ resulting difference between the regional calculated base curve and the observed curve is minimal and no adjustment to the base curve is warranted.

Comparison of the two profiles indicates a single negative anomaly of amplitude 5.25 mgals spanning the interval $\mathrm{km}$ 98.25-106.8. Several comparatively short wavelength, less than $1 \mathrm{~km}$, anomalies are superimposed on this feature.

Completed Detailed Model

The completed Fourth Plains local model and its associated observed and computed Free Air curves are shown in Figure 17. The observed curve is indicated by a solid line for clarity and does not represent a continuous knowlege of the observed gravity behavior. Locations where specific values for the observed curve are known coincide 


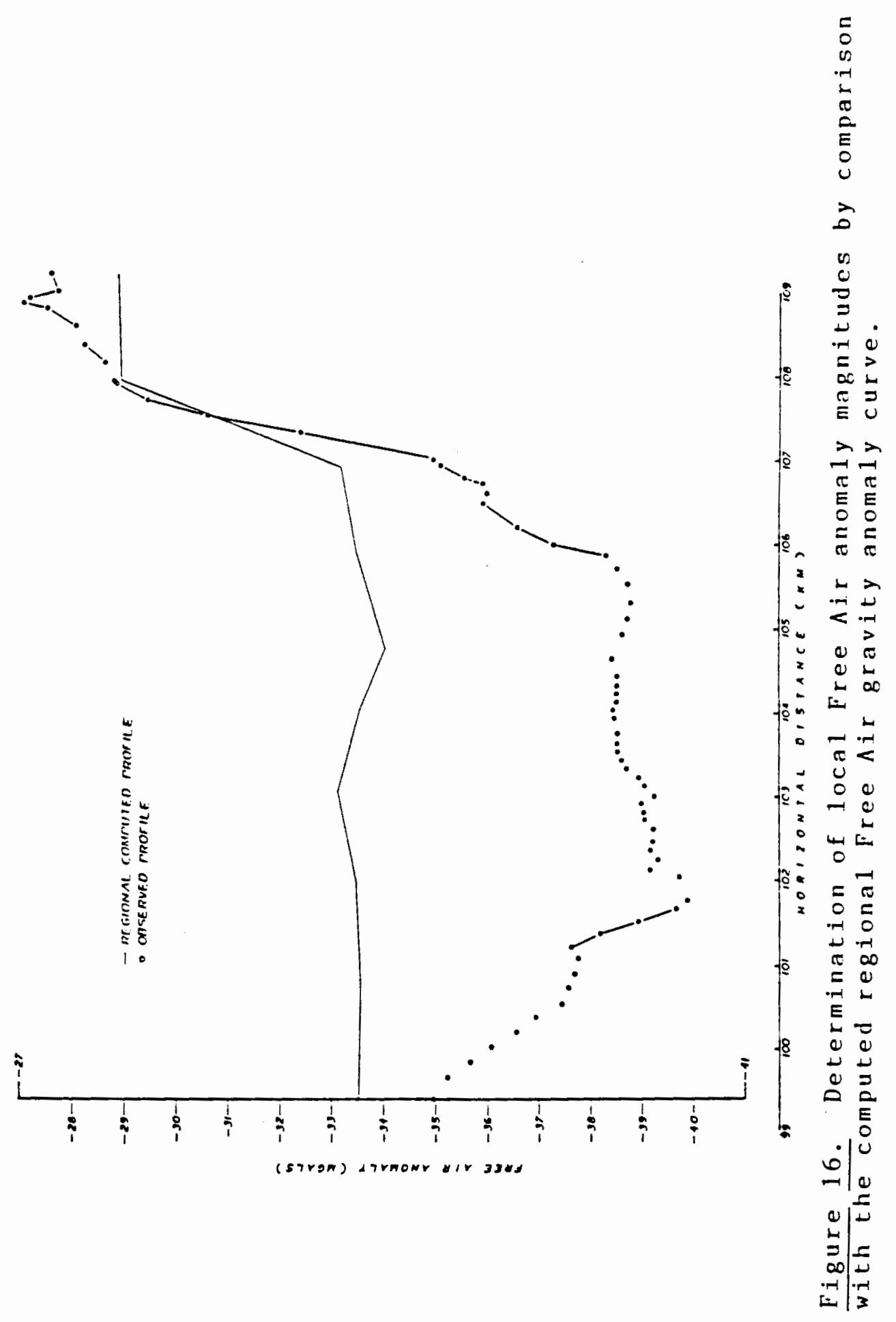




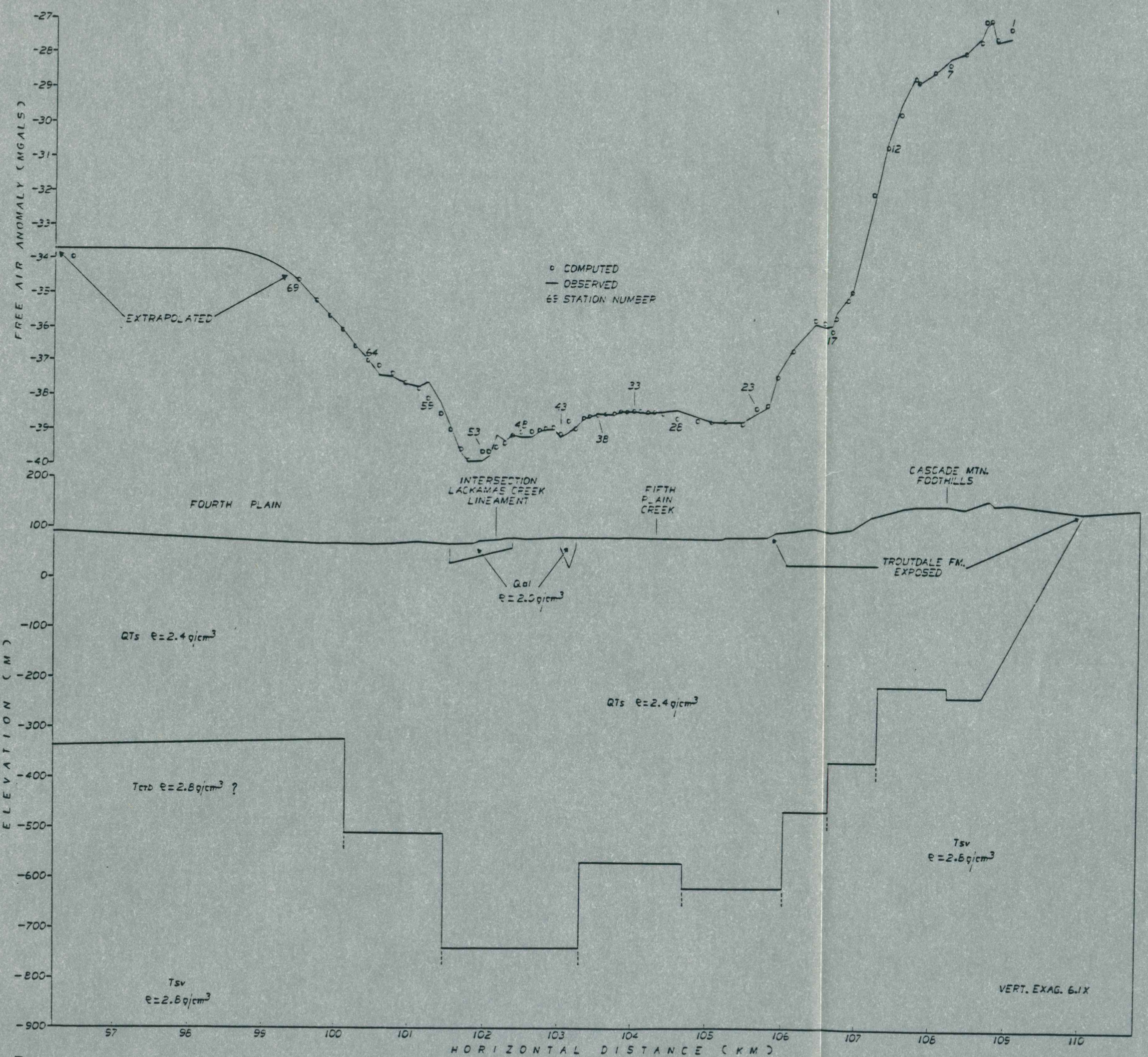

Figure 17. Observed and computed local Free Air anomaly profiles and completed local model of the Fourth Plains line. 
on a vertical axis with the locations shown for computed stations. Total gravity fluctuation for the local line is approximately 12 mgals. A -27.5 mgal high gravity value occurs in the region of $\mathrm{km} \mathrm{108.5,} \mathrm{undoubtedly} \mathrm{reflecting} \mathrm{a}$ considerable contribution due to the increased elevation (and therefore mass) beneath stations in this part of the curve. The local lines low gravity value of -39.5 mgals occurs at $\mathrm{km} \mathrm{101.6.} \mathrm{A} \mathrm{portion} \mathrm{of} \mathrm{the} \mathrm{gravity} \mathrm{fluctuation,}$ approximately $6.25 \mathrm{mgals}$ of the total $12 \mathrm{mgals}$, lies in the interval km 105-110 where it is generated by the combined effects of an anomaly producing body (APB) and a strong elevation component. The remaining 5.25-5.75 mgals are expressed in the interval $\mathrm{km}$ 96-104 where elevation changes are insignificant and the observed anomaly can be considered primarily due to a near surface APB. Agreement between the observed and computed curves ranges from coincidence to $\pm 0.53 \mathrm{mgals}$ with a mean value of 0.008 mgals. Approximately 39 percent of the computed stations match their observed values better than the $0.06 \mathrm{mga} 1$ maximum reasonable measurement error providing a good quantitative match.

Well control for the Fourth Plains local model is poor. Numerous groundwater wells exist and have been used to establish the stratigraphic relationships of surface sediments, (Mundorff, 1964); however, excellent aquifers were so readily found that none of the wells were drilled to basement. 
Considering this lack of geologic control, detailed modeling began with the Interstate line in an effort to help establish any structural parallels that might exist. A similar stratigraphy was arrived at for the Fourth Plains model based on the following criteria: 1) projection of existing well-based geologic data - which suggest a fair degree of basin symmetry, 2) analysis of topography, geologic contacts and structural trends - which show no major changes in type, structure or number of units involved and 3 ) consistent nature of the regional gravity trend - the regional gravity trends of both lines are quite similar.

Two modeling units were required to bring the observed and computed curves into general agreement. Because individual formations within the model are only locally differentiated and since gravity can not distinguish between units with similar densities; it was necessary to combine formations based on their major lithology. The overburden sedimentary unit represents the combined occurrence of the Troutdale Formation and the Sandy River Mudstone (QTS) while basement strata is composed of Columbia River basalt and/or Skamania volcanics (Tcrb-Tsv). Since it is not recognized in wel1 data or outcrop the occurrence of the Tcrb in the area has not been established. It has been symbolically included in the local model since its occurrence here is likely. The 
impact of its presence or absence on modeling is minimal however, since both the Tcrb and Tsv are assumed to have identical densities. The depth and structure of the volcanic basement, rather than what the basement is composed of, becomes the primary concern. The inclusion of a third modeling unit of low density alluvium (Qal) was neccessary at km 101.5 and $\mathrm{km} 103.25$ to correct for short wavelength variations which could not be accomodated by adjustments of the QTs-Tsv interface. These alluvial units have been mapped by Trimble (1963) at these locations. A density contrast of $0.4 \mathrm{~g} / \mathrm{cm}^{3}$ was assumed between Qal-QTs units and QTs-Tsv strata. As indicated by the model, sediment thickness in the Fourth Plains line is approximately twice that which occurs in the Interstate line. The effect of this condition on an observed anomaly is to reduce the slope of the observed curve over an APB boundary. Regardless of this, the model requires several near vertical boundaries ranging in magnitude from approximately $50 \mathrm{~m}(164 \mathrm{ft})$ to $225 \mathrm{~m}(738 \mathrm{ft})$.

As with the Interstate 1 ine, any divergence from the vertical character of these unit boundaries would require the introduction of small localized high and low density contrast bodies, the existence of which are not known.

The primary purpose of the Fourth Plains line was to investigate the northern extent of the Lackamas Creek lineament where it is lost beneath a cover of QTs sediments and Qal alluvium. Significanty, its intersection with the 
local line is expressed in the observed gravity curve as a negative anomaly and in the local model as a negative relief feature. Of equal importance is the perfect alignment of major structures in the Interstate and Fourth Plains lines along the strike of the Lackamas Creek lineament. 


\section{DISCUSSION AND CONCLUSIONS}

\section{Introduction}

It is possible, from a geological perspective, to produce the gravity anomalies observed in the Interstate and Fourth Plains lines by at least three distinct mechanisms. These processes are faulting, folding and erosion. Each has been shown to have produced significant features within the basin and its surrounding region.

It is reasonable to expect that model analysis can provide some basic ideas of the basin margin's structure and morphology yielding a framework for interpretation. It appears advantageous in this case to embrace the problem by considering each process in turn, delineating strengths and weaknesses.

For the remainder of the text the combined Columbia River basalt and Skamania volcanics will be refered to as "basalt" or "basement" and the combined Troutdale Formation and Sandy River Mudstone will be referenced as "sediment" or "overburden". Exceptions to this will be made where neccessary. As an aid to the discussion, Figure 18 is presented to clarify Columbia River basalt succession.

\section{Folding}

Prior to this study, presumed eastern margin structure consisted of a synclinal limb, locally expressed 


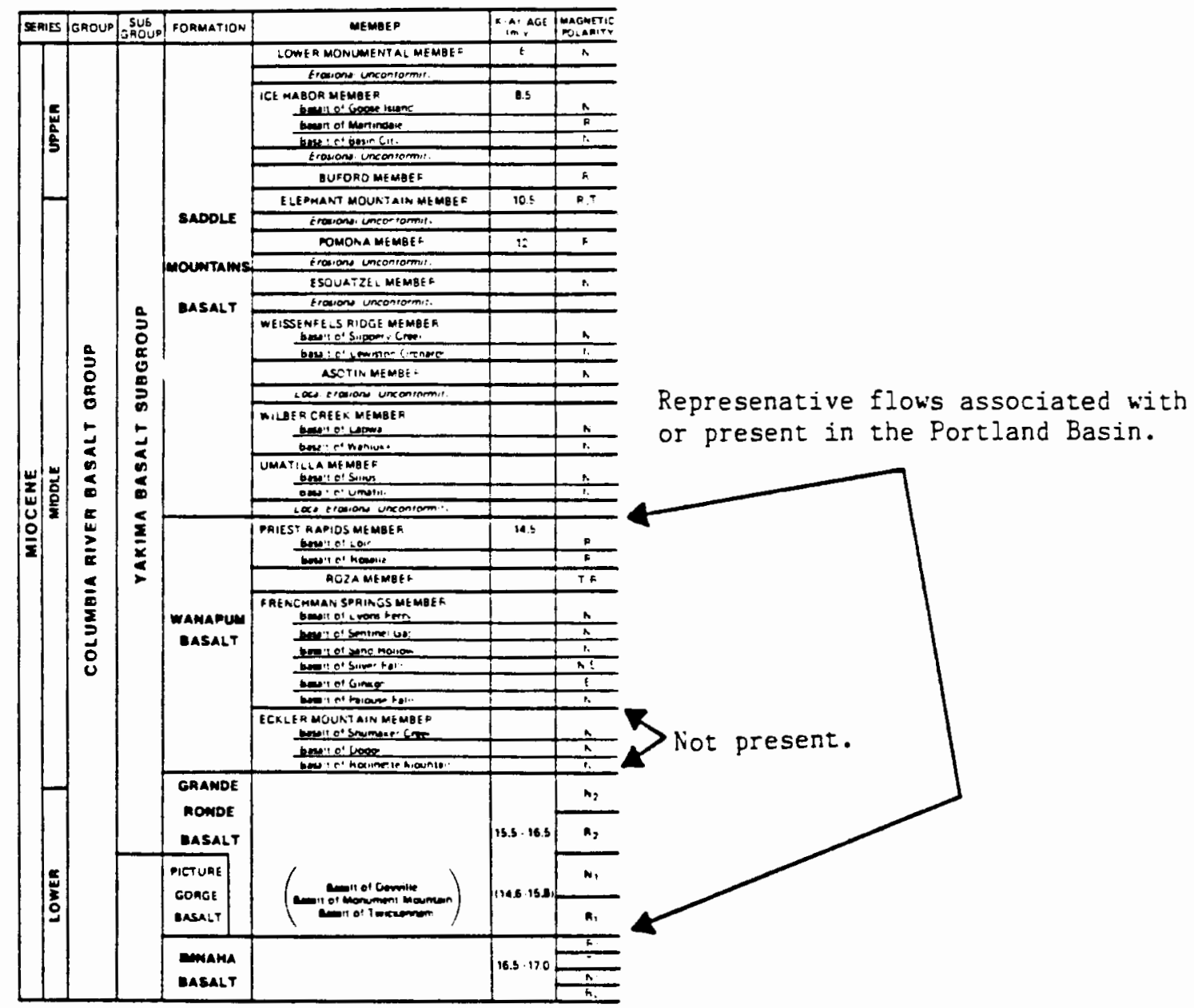

Figure 18. Stratigraphic nomenclature, age and magnetic polarity for the Columbia River Basalt Group (in Tolan and Beeson, 1984). 
as a homocline, dipping gently westward (Trimble, 1963). If one assumes a regional compressive stress regime for the Portland Basin during its generation (Trimble, 1963; Beeson and others, 1976; Perttu, 1980), then notable folding might have occurred within the basin or along its margins outside the confines of the Portland Hills structure. The existence of tight asymetric box folds along the eastern margin might conceivably produce observed gravity curves similar to those found in the Fourth Plains and Interstate profiles. The depth of folding and the extent to which basement 1 ithologies are involved can not be determined, although it is assumed that the Columbia River basalt would be deformed.

Asymmetric anticlines with wavelengths of only a few kilometers and amplitudes generally $<1 \mathrm{~km}$ are common in the Yakima Fold Belt of the western Columbia Plateau. Anticlinal axes trend primarily east-west, however, they range from west-southwest to northwest (Caggiano, 1981). There is no evidence that folding in the study area is an extension of this deformation. Conversely, Tolan and others (1984) have established a westward terminus of the Yakima Belt beneath the northern Oregon Cascades, where structural axes trend west-southwest, perpendicular to and falling short of, the study area structures.

Beeson and others (1985) have described the morphology of this Yakima Belt extension. They note that 
large folds are formed, usually with wavelengths of 10-20 kilometers and limbs that display variable dips generally less than 15 degrees. Commonly before the 15 degree limit was exceeded failure occurred, usually near the anticlinal axis where post rupture strain was present as overthrust. In sharp contrast only tight asymmetric folding of the basement could satisfy the requirements of the gravity models.

Because nearby folding is not of the type required by the models does not mean that folding can be discarded as a generative process, but more likely suggests that the two deformations are probably not related. This of course means that folding, apparently autonomous from surrounding deformations could be present at depth. If this is true, then the folds would have to themselves be faulted. This is because both models contain well defined small scale features that are inconsistent with smooth limb surfaces. Indeed, modeling becomes increasingly difficult as the sharpness and brevity of the structures shown in the two completed local models is smoothed. The closest and most easily attainable match between observed and computed gravities occurs when faults rather than folds are used in the models.

While undoubtedly some loading has occurred, it seems unlikely that sediment thickness ever exceeded a maximum of 300-600 m; considerably less than the kilometers of overburden usually associated with plastic deformation, 
thus making this type of behavior doubtful.

The problem of eastern margin folding can not be satisfactorily resolved in this study. Because no supporting evidence exists for folding and because such an unusually extensive and uniform deformation is required, an eastern margin development through tight asymetric folding appears inadequate. This study assumes that in the study area the Columbia River basalt behaved as it does in other regions of the basin; essentially as a brittle member with a tendency to fail before being folded through large angles.

\section{Channeling-Erosion}

In the interest of simplicity and because a broader data base is available, the channel hypothesis will be discussed with emphasis on the Interstate line. It should be noted that this line crosses the lineaments in an area crucial to the understanding of both. Any arguement developed here can be applied to both lineaments (with some modification) since it is assumed that they are genetically related.

Tolan and Beeson (1984) have recently provided an outline of the Neogene history of the Columbia River. This was accomplished through improved delineation of key members within the Columbia River Basalt Group and their relationship to an incipient Portland basin and Cascade Range. Several paleo-channels of the Columbia were 
identified east of the study area within the Cascades. Each varies in morphology, host lithology and in turn becomes progressively younger northward. Some can be traced great distances westward, in some cases as far as the Pacific coast.

It is important that the relationship between flows of the Columbia River basalt and the ancient river system be realized. Significantly, the reason for the multiplicity and preservation of these paleo-channels was the low viscosity, large volume and resistence to eroson of the Columbia River basalt, in particular certain units of the Frenchman Springs, Priest Rapids and Pomona members. Typically magma extruded on the interior plateau reached the headward canyon of the Columbia producing an intracanyon flow. In several instances these courses were filled and overtopped causing displacement of the river and formation of a new channel (Tolan and Beeson, 1984). It is concieveable that a concealed ancient channel filled with low density sediment rather than high density basalt might generate the anomalies observed in the gravity 1 ines.

During the time interval approximate $1 \mathrm{y} 2-15 \mathrm{~m} \cdot \mathrm{y} \cdot \mathrm{b} \cdot \mathrm{p}$. the ancestral Columbia was hosted in one of three major structures and/or channels (Figure 19). Tolan and Beeson (1984) have constrained the time the river occupied the older Mount Hood-Dalles and Mosier-Bull Run synclines to the narrower period of approximately 14-15.5 m.y.b.p.. 


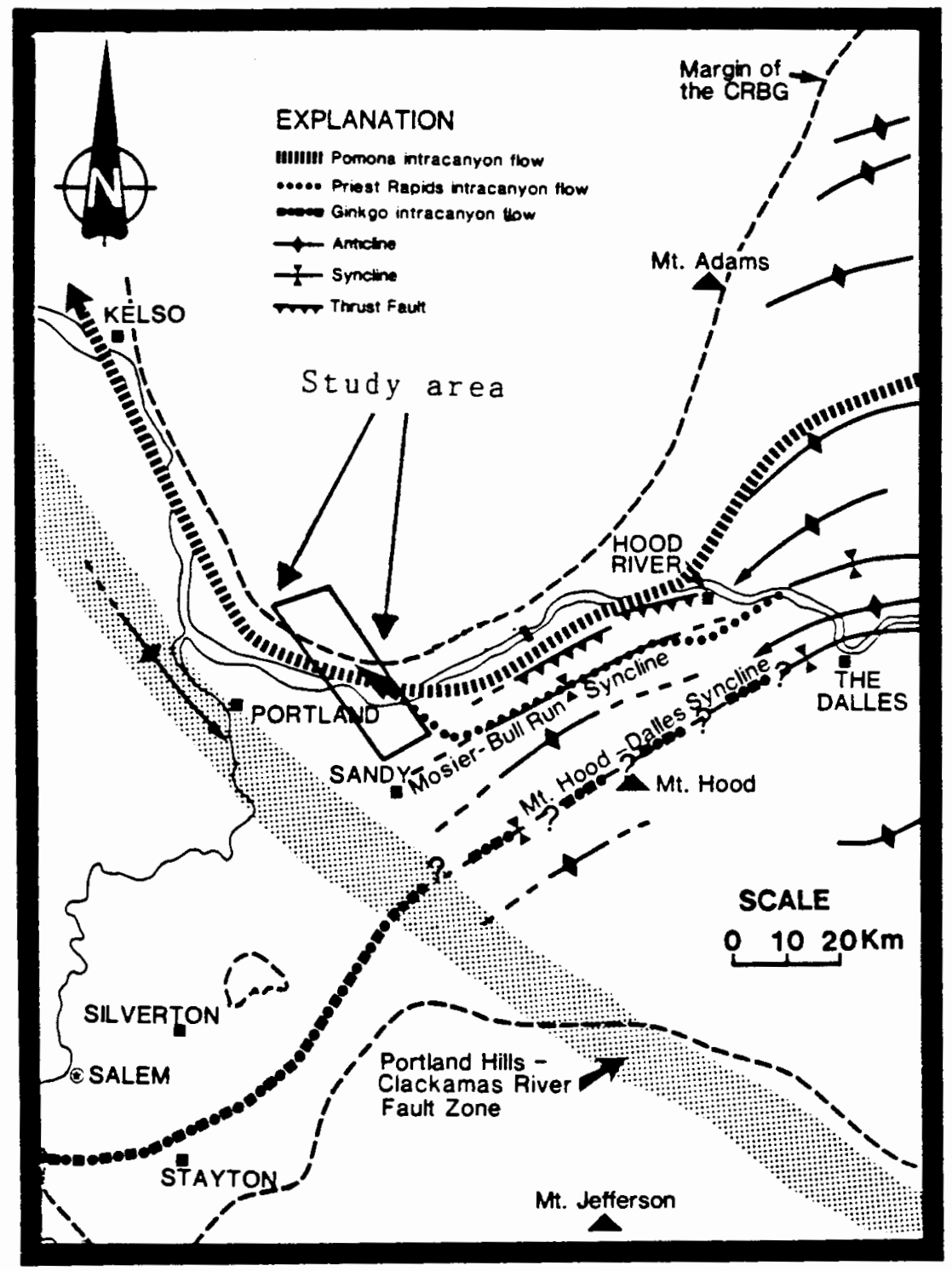

Figure 19. Distribution of major controlling structures and paleo-channels of the Columbia River and their relation to the study area (from Tolan and Beeson, 1984). 
The models suggest that it is reasonable to expect the coincidence of both negative anomalies and anomaly producing bodies with both lineaments along their entire lengths. Presumably these three entities; negative anomaly, anomaly producing body and lineament are genetically related. If Columbia River channeling is responsible for the anomalies observed in the Interstate line, then it would likely be responsible for all the anomalies and lineaments identified in this study.

Because of the relative ages and spacial associations of the known channels, it is implied that the Columbia was introduced into the study area through the southernmost Mount Hood-Dalles or Mosier-Bull Run structures. Younger channels lie too far north to have been responsible for the more southerly portions of the Sandy River lineament.

The stratigraphy of the Interstate line, like that of the study area in general, is relatively simple. Apparently undisturbed sections indicate $100-300 \mathrm{~m}$ of overburden capping a volcanic basement which continues to depth. If the channel hypothesis is correct then the following must certainly be true. Either the channel is hosted entirely within the basement, the overburden, or is hosted to a greater or lesser degree by both units.

We can recall from the Interstate model certain physical parameters of its major anomaly. Any channel must: 1) produce a significant negative density contrast of at least $0.4 \mathrm{~g} / \mathrm{cm}^{3} \quad$ 2) have general dimensions no 
greater than $3000 \mathrm{~m}$ in width and $300-400 \mathrm{~m}$ in thickness and 3) attaining a channel bottom elevation no deeper than -450 $m$. Any placement of a channel must satisfy these physical constraints.

The emplacement of Skamania strata predates the earliest known existence of the Columbia River. Because of its relative high density $\left(2.8 \mathrm{~g} / \mathrm{cm}^{3}\right)$ its replacement by sediments could produce significant anomalies. Regardless, this is unlikely since a Skamania hosted channel would eminate from too great a depth. If we smooth the indicated structure in Figure 14 and allow a conservative uniform thickness of $100 \mathrm{~m}$ for the Grande Ronde basalt then we could expect to encounter Skamania strata at a depth of $250 \mathrm{~m}$ in the 107-111 $\mathrm{km}$ interval. A minimum thickness in the neighborhood of $400 \mathrm{~m}$ would still be required for the anomaly producing body, placing its termination at the -650 $\mathrm{m}$ level. This is $200 \mathrm{~m}$ beyond the maximum depth limit allowed for the channel. At this depth an increase in thickness and/or density contrast would be required to preserve the shape and magnitude of the observed anomalies. The restriction of the depth constraint can be lessened if we allow the channel to exist during Columbia River Basalt time. In this situation the channel must be hosted in both units because the indicated thickness of Columbia River basalt is insufficient to accomodate the channel in its entirety. 
It is doubtful a channel in the study area could have survived Frenchman Springs time (that time when the channel was primarily located in the Dalles-Mount Hood syncline) to be later filled by the more sluggish process of sedimentation. This seems apparent because of the wide distribution and mode of occurrence of these flows.

Several wells in the study area (more specifically, previously described heat flow and water wells near the Interstate line) indicate uniform thicknesses for both the Sand Hollow and Sentinel Gap units of the Frenchman Springs Member. Indeed Tolan and others, (1984) note that:

Because of their wide distribution, flows of the Frenchman Springs Member not only inundated and destroyed the ancestral Columbia River channel in western Oregon but also destroyed the existing and developing drainage systems throughout most of the Columbia Plateau.

If we can assume intracanyon flows inundated and overtopped the ancient Dalles-Mount Hood channel during Frenchman Springs time and it appears we must, then the argument is reduced to a question of sufficient density contrast. Since in this case basalt would replace an exact or similar lithology of identical density, then no density contrast could be produced.

It is also doubtful that the proposed channel could have existed during the time the river occupied the later Mosier-Bull Run structure (Figure 19). Within this structure the river flowed southwest along much of its identified course until turning sharply northwest forming the well exposed Priest Rapids channel at Crown Point. It 
is possible that at some point during its occupation of the Mosier-Bul1 Run syncline the Columbia ranged a few kilometers farther west and at this time erroded the hypothetical channel. This possibility is limited by the following:

1) Lack of proper topographic control - Much of the present topography surrounding the Interstate line did not exist during Frenchman Springs - Priest Rapids time. The uplift of the high Cascades, the erruption of the Boring Volcanics and the deposition of the Troutdale Formation had not yet begun. The topography was less pronounced, contributing to the widespread distribution of Frenchman Springs flows. The river's course after leaving its syncline channel was still probably dictated by some sort of topographic control. As it approached the study area from the east a structural-topographic control was readily provided by a then incipient Portland basin, the first development of which is indicated by the pinchout of some Grande Ronde Basalt flows over a Portland Hills structural high (Beeson and others, 1976). If the hypothesis is true and at some time during its occupation of the Mosier-Bull Run structure the river ventured farther westward than is presently known; then its expected course would be downslope, perpendicular to the basin's axis, hence preventing it from producing the anomalies. 
2) No evidence of catastrophic blockage - Eventhough Cascadian volcanism spans this time, there appears to be little evidence of materials and/or events which could have caused abandonment of this course so that it could be established at Crown Point. Tolan and others (1984) have described partial and/or complete blockage of the later Bridal Veil channel, but it seemes the river's course while in the Mosier-Bull Run syncline was probably dictated by features of low relief, perhaps in some way aided by the termination of the structure. Beeson (pers. comm., 1986) finds no evidence to suggest the ancient river ever varied from the identified course beneath Crown Point. He contends the river could have been captured by the headward erosion of a smaller northwest trending stream.

The remaining 12 million years of Columbia River history are better understood. Upon destruction of the Priest Rapids channel by the Rosalia flow of the Priest Rapids Member the Columbia again moved northward establishing the Brial Veil channel were it remained for the next 10 million years. It was forced to incise its present channel, where it has remained for the last two million years, because of wide spread volcanism and sedimentation related to the onset of Cascadian uplift (Trimble, 1963; Baldwin, 1981).

Another account of an abandoned channel is provided by Mundorf (1964) where he describes a Pleistocene path of the Columbia coincident with the southernmost portion of 
the Lackamas lineament. Apparently at the mouth of the present gorge the river veered northwesterly and eventually split into two channels near Orchards, Washington. The river eroded surficial sediments until it encountered more resistent beds of the Troutdale Formation. Even though the river was coincident with the Lackamas Creek lineament at this location it could not have produced an anomaly because of an insufficient density contrast between the sediments involved. Further erosion to include Columbia River basalt and/or Skamania strata would be required, but was not noted.

In 1 ight of the discussion presented here it is doubtful that the ancestral Columbia ever occupied a course coincident with either lineament in this study. More unlikely is the possibility that the river was present at the proper time. It seems clear that if the proposed channel was older than the Columbia River basalts then the hypothesis would violate depth constraints, and if younger would not produce a density contrast, either because the canyon would have been filled by basalt or because the channel itself was hosted in sediment.

\section{Faulting}

In contrast with the possibilities explored to this point, faulting can be shown to be a reasonable generative process for the development of the eastern margin. 
The Washington Department of Natural Resources in an as yet unpubished regional geologic map has interpreted limited faulting along the western shore of Lackamas Lake, forming a portion of the southern most extension of the Lackamas Creek Lineament. Stratigraphic studies within the basin undertaken by Swanson (pers., comm., 1986) suggest faulting in this area. Considering the inadequacies of alternative processes and the strong topographic suggestion the arguement for faulted structure seems convincing. Unfortunately, to a large degree no furthur evidence to support faulting (i.e., exposed offsets or slickensides) along either lineament are known to exit, presumably because they are obscured by young sediments.

Both gravity models tend to confirm the existence of a fault or faults along the eastern margin of the Portland basin. In fact, they are more consistent with this interpretation than either of the previously explored possibilities. Indeed the best gravity fit and the most apparent and accomidating process for the generation of eastern margin structure is large scale en echelon faulting exhibiting an element of graben-like morphology. Herein these structures will be called the Lackamas Creek and Sandy River faults, which coincide with their like named and previously described lineaments.

Nearly all recent structural interpretations of the basin or its parts have been based on Trimble's (1963) original concept. His asymetric syncline served as a 
reliable base model which was later modified. Benson and Donovan (1976) compiled the Preliminary Tectonic Map of the Portland Basin based on the syncline concept. Beeson and others (1976) refined the model through a better characterization of the Portland Hills complex. Perttu (1980) investigated the possible existence of additional faults within the basin using gravity methods. She determined that displacement in the eastern regions of the basin was either small scale or was distributed over enough structures to be undetectible given the resolution of the surveys.

Recent speculation (Beeson and Tolan, 1984) holds that the basin is a pull-apart associated with wrench tectonics. While the basin diplays characteristics of syncline, graben and pull-apart structures this study indicates that only the latter form, or more pecisely its tectonic regime, allows sufficient diversity to produce the noted overall basin morphology.

If the Portland basin is synclinal, then it is also terminated normal to its axis by major faults. A syncline or syncline-like feature may have been generated if a proper and considerable drag sense were applied to the strata along these failures. Although such as drag sense is allowable when considering earlier gravity surveys across the Portland Hills structure (Beeson and others, 1976), it is neither required or suggested by either model 
of the eastern margin. A proposed synclinal basin unneccessarily complicates the basin's stress history by requiring an initial compression and later incipient extension or at least relaxation of compressional stresses. The eastern margin has clearly undergone at least minor extension as evidenced by the graben-like morphology of the Lackamas Creek and Sandy River Faults.

It is simpler to assume that the basin was formed under a general tensile stress. The south plunging anticline and westward dipping (fault plane) overthrust (Tolan and others, 1984) which occur in the Portland Hills complex are probably associated with dominant dextral movement. This interpretation would dictate that the development of the complex resulted from a localization of shear stress on the structure, not requiring the transmission of significant compression across it.

Equally troubling is the graben concept. In a classic sense the basin should be bounded by normal faults. Whether the Portland Hills Fault exhibits any significant normal component must be questioned. Indeed the actual attitude of the failure plane has never been established and various depictions of the complex have been influenced by the syncline/anticline model predominant at the time. Because of the relationships established at the eastern margin of the basin, in particular those that suggest wrench tectonics; movement on the Portland Hills fault might be better considered as wrench in nature. 
Further indication that the basin is not strictly a graben is the irregularity and inconsistency of the basement. The basement displays or implies several low and high relief areas (in contrast to an idealized downfaulted block) which appear to be structurally controlled. Examples of local "highs" would be the occurrences of Skamania volcanics on Lady Island (Trimble, 1963) and the Tillamook volcanics near Milwaukie, Oregon (Beeson, pers. comm., 1983). "Lows" include areas with deep basement, such as the Portland Well Field (Hoffstetter, 1983) and/or the Fourth Plains region. Of primary importance is the realization that at least in the vicinity of the Interstate line the eastern margin has independently developed a graben-1ike structure at the expence of basin wide subsidence. The Interstate local model indicates that basement in the Fairview well may have experienced little if any subsidence, effectively localizing the deformation immediately eastward. The lack of identified meaningful graben-style structural boundaries of anything more than local extent seems to be general. Because of this, establishing a graben model is difficult.

Perhaps the most striking agreement of theory and observed structure can be made utilizing wrench tectonic theory, in particular that which deals with the formation of pull-apart basins (Aydin and Nur, 1982). The existence of secondary structures such as overthrusts (Beeson and 
others, 1985), normal faults and anticlinal flexures in direct association or close proximity to the Portland Hills dextral failure is typical of a wrench regime. Figure 20 shows the general spacial relationships and stress orientations (end effects) encountered in a wrench regime generated by dextral and sinistral stepovers. It is likely that the ends of strike slip faults magnify stresses that facilitate the formation of secondary structures. Figure $20 \mathrm{~A}$ shows the areas where extensional (open wedges) and compressional (zigzag lines) structures would likely be formed around a dextral system. Figures 20B, 20C and 20D indicate the shape and extent of these areas depending on the degree of overlap and the right or left hand nature of the stepover. It can be shown that right-stepping and left-stepping dextral strike-slip faults produce tension and compression, respectively, in the overlapping areas yielding pull-apart basins at right stepovers and uplifted regions at left stepovers (Aydin and Page, 1984). The orientation of these secondary structures depends, of course, on the distributions of stress, the geometry of the faults and the dimensions and distributions of the materials involved. Idealized representations of these structures are shown in Figures $20 \mathrm{E}$ and $20 \mathrm{~F}$ where hachures represent normal faults and barbs are reverse faults. Filled marks indicate vertical movement (up or down) and empty marks indicate dip slip component on segments of strike-slip faults. The application of this type of model 


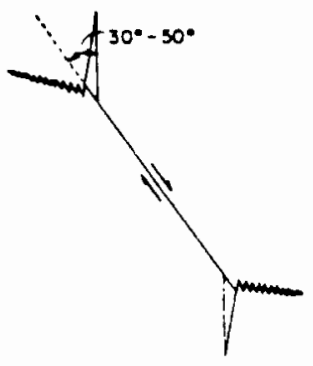

A

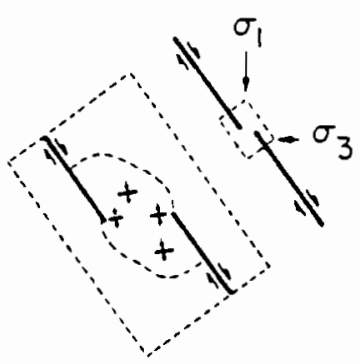

D

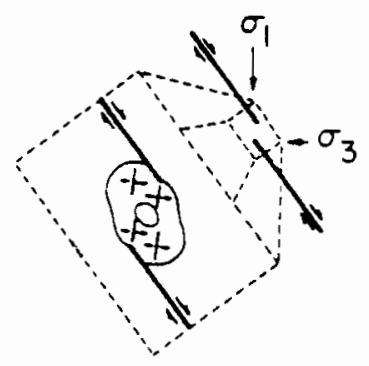

B

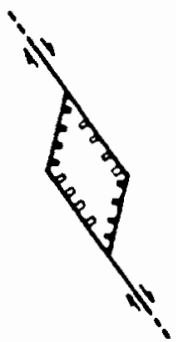

E

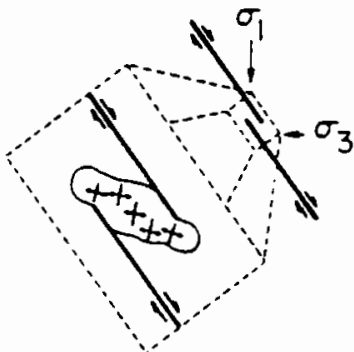

C

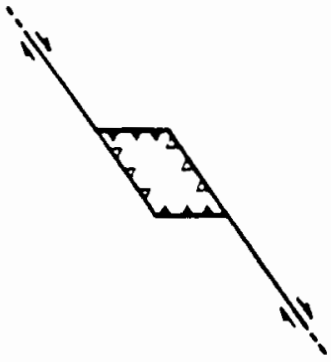

$F$

Figure 20. Orientations of structures associated with ends of strike-slip faults and stepovers between en echelon strike-slip faults (from Aydin and Page, 1984). 
to the Portland Hills complex would be preliminary in nature and should await furthur study, however, the parallels are intriging and compelling.

In a basin wide context the application of strikeslip "end effects" and stepovers is questionable. Certainly not because the tectonic regime has somehow changed, but rather because the evidence of strike-slip caused structures or at least their geometry is not as clearly evident. These features require the stress concentration provided by the termination or interaction between strike-slip faults. No termination of the Portland Hills Fault in the vicinity of the basin has been demonstrated and investigation of the eastern boundary faults indicates these faults are extensive, at least bounding and possibly extending well beyond the known basin. Considerable strike-slip movement would be required along the eastern margin if these faults were to play a role in the development of a pull-apart the magnitude of the Portland basin. No movement can be demonstrated, nor is it implied, at least on a large scale.

Figure 21 illustrates the application of simple dextral stepover theory combined with the structure dictated by the models, in the case of the eastern margin. Here the Lackamas Creek and Sandy River faults form an en echelon set of faults which overlap for a fraction of their extent effectively concentrating stresses in the region of 


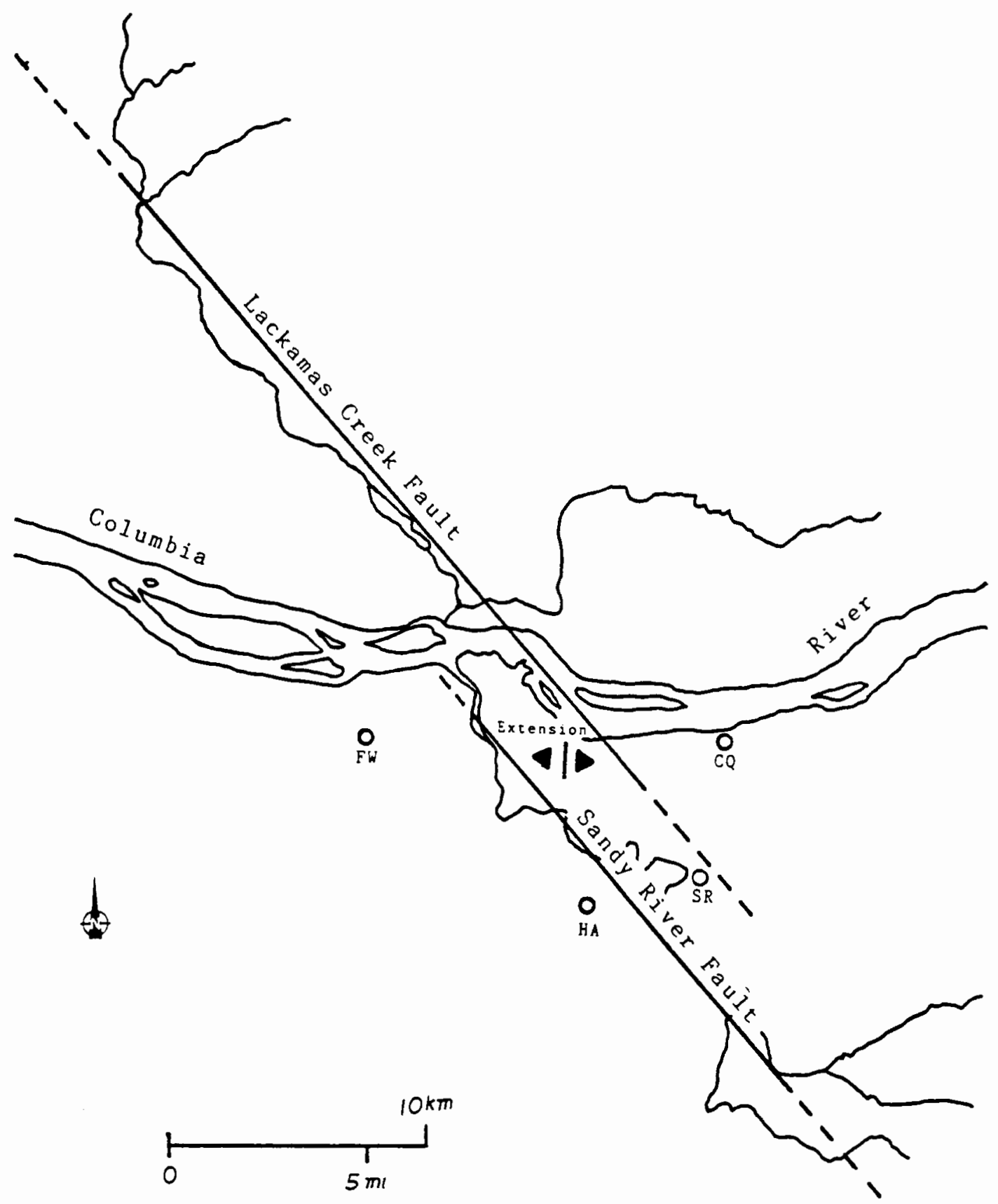

Figure 21. Sandy River and Lackamas Creek Faults. Faults are generaliy down to the west but are often graben-like. Note dextral stepover and area of amplified extension. Also indicated are the locations of the FW - Fairview well, CQ - Corbett Quarry well, HA - Hood Acres well and SR - Sandy River control wells. 
the stepover. A pull-apart would express itself as the major anomaly of the Interstate 1 ine providing the impetus for the subsidence of this area and its topographic effect on the course of the Columbia River. Most secondary structures if present would be hidden by Troutdale sediments although the deformation of the Blue Lake - Lady Island region might represent a secondary compressional feature.

Both gravity models indicate extension along the margin. However, some shear stress along the structures would be required to form a pull-apart and could have been imparted early in its generation. Because of its limited extent a pull-apart basin of this size would require such a stress for a relatively short period of time, perhaps only during the initial formation of the faults. Aydin and Nur (1984) indicate that an almost unlimited number of situations involving stress, fault orientation and developmental rate are possible. Undeniably this interpretation is preliminary, yet the tectonic relationships upon which it is based are consistent with the structural geometry as dictated by the models, the prevelence of related basin wide features and the topographic morphology of the margin. The sequence of stresses and indeed the magnitude of any strike-slip movement which may have occurred on either fault is unknown . 
Regardless of how one interprets basin structure it appears the eastern margin began its development later than its western counterpart. This is certainly true of the region surrounding the Interstate line where flows of the Frenchman Springs Member are involved in faulting they would have inundated had the structure pre-existed them. Beeson and others (1976) noted that early development of the Portland Hills structure occurred during Grande Ronde time, evidenced by flows of this member which pinched out westerly against the complex. Conversely there is little indication of structural development within the study area before the end of Sand Hollow or Sentinel Gap deposition. These Frenchman Springs units were the stratigraphically highest chemically determined basement which appeared in the control wells (Figure 21). Some early (near Vantage time) deformation can be inferred from the Hood Acres well where an isolated $16 \mathrm{~m}$ thick Ginko flow of the Frenchman Springs Member occurs in addition to some increased total Frenchman member thickness. This divergence has little effect on general interpretation since it appears to be local and because it has not been established whether it was caused by erosional or structural forces. In effect, there appears to have been no general thickening or exclusion of units across the structures. The contention that deformation was delayed in the study area is furthur supported by the stratigraphic effects of the geophysical requirement that a negative gravity anomaly be provided. 
If significant faulting of the eastern margin occurred simultaneously with the deformation and uplift of the Portland Hills and therefore with the deposition of Columbia River basalts, then those areas of subsidence would aquire locally thickened basalt sections. Since these thickened sections would be down-faulted into older basalts and Skamania basement of equal density then no contrast or anomaly could be produced. If sedimentation rates were high during this time then alternating lenses of sediment and basalt would accumulate in the grabens, the thicknesses of which would be determined by deformation rate. In this instance the ability of the downthrown blocks to produce a low density body would be greatly reduced, requiring unrealistic displacements. This possibility is limited by a noted lack of volumetric sedimentation throughout the basin during basalt deposition. The greatest noted sediment thicknesses occur as the sands and clays of the Vantage Horizon, which rarely exceed a few meters and have been interpretted to represent a low sediment rate, reducing environment (Beeson and others, 1976). Of course structural inactivity during basalt deposition would have no stratigraphic or geophysical expression.

Deformation of the eastern margin did not begin then until late Frenchman Springs time, perhaps .5 m.y. after its onset in the Portland Hills. It is probable that the 
eastern margin developed as a response to shear activity along the Portland Hills complex. This activity caused a general basin wide tension, in addition to transmitting a component of shear which caused its incipient wrench like failure.

It would appear that the principles and concepts of wrench tectonic theory, in particular that which deals with secondary structure and stepover phenomena has valid application in the Portland Basin. The extent to which the basin conforms to these principles is uncertain. It is likely nonetheless that this type of tectonism has been active here and is responsible for the basin's development. Of particular importance to the success of the application of the theory in the Portland basin is the accurate delineation and interpretation of its east bounding Lackamas Creek and Sandy River faults and their relation to the western boundary complex. The emphasis of furthur study should be focussed on this relationship in order to gain a more refined understanding of these structures and the role they have played in regional tectonic history. 


\section{REFERENCES CITED}

Allen, J.R., 1975, Volcanoes of the Portland area, Oregon: Ore Bin, vol. 37, no. 9, p. 145-157.

Anderson, J.L., 1978, The stratigraphy and structure of the Columbia River Basalt in the Clackamas River drainage: unpublished thesis, M.S., Portland State University, Portland, Oregon.

Atwater, T.M., 1970, Implication of plate tectonics for the Cenezoic tectonic evolution of western North America: Geol. Soc. America Bul1., v. 81, p. 3513-3536.

Aydin, A. and Nur, A., 1982, Evolution of pull-apart basins and their scale independence: Tectonics, v. 1, p. 91105 .

Aydin, A. and Page, B.M., 1984, Diverse Pliocene-Quaternary tectonics in a transform environment, San Francisco Bay region, California: Geological Society of America Bulletin, v. 95, p. 1303-1317.

Baldwin, E.M., 1981, Geology of Oregon, 3rded., Kendall/Hunt Publishing Company, Debuque, Iowa, 147p.

Beck, M.E., Jr., and Burr, C.D., 1979, Paleomagnetism and tectonic significance of the Goble Volcanic Series, southwest Washington: Geology, v. 7, p. 175-179.

Beeson, M.H., Fecht, K.R., Reidel, S.P., and Tolan, T.L., 1985, Regional correlations within the Frenchman Springs Member of the Columbia River Basalt Group: New insights into the Middle Miocene tectonics of northwestern Oregon, Oregon Geology, v. 47, no. 8 .

Beeson, M.H., Johnson, A.G., Moran, M.R., 1976, Portland environmental geology - fault identification; Final technical report to the United States Geological Survey: Earth Sciences Dept., Portland State University, Portland, Oregon. 
Benson, G.T., and Donovan, J.C., 1974, Preliminary tectonic map of the greater Portland area: in Hammond, P.E., and others, 1974, A preliminary geological

investigation of the ground effects of earthquakes in the Portland metropolitan area, Oregon: unpublished report to the United States Geological Survey (PEG I report), Portland State University, Portland, Oregon.

Berg, J.W., and Thiruvathukal, J.V., 1967a, Free air gravity anomaly map of Oregon: Oregon Department of Geology and Mineral Industries, GMS 4a, scale 1:500,000.

Berg, J.W., and Thiruvathukal, J.V., 1967a, Complete Bouguer gravity anomaly map of Oregon: Oregon Department of Geology and Mineral Industries, GMS 4b, scale $1: 500,000$.

Bonini, W.E., Hughes, D.W., and Danes, Z.F., 1974, Complete Bouguer gravity anomaly map of Washington: Division of Geology and Earth Resources, State of Washington, Department of Natural Resources, geologic map GM-11, scale $1: 500,000$.

Bouchard, H., 1965, Surveying; International Textbook Company, Scranton, Pennsylvania, 754 p.

Bromery, R.W., and Snavely, P.D., Jr., 1964, Geologic interpretation of reconnaissance gravity and aeromagnetic surveys in northwestern Oregon: United States Geological Survey Bulletin ll81-N.

Caggiano, J.A., 1983, Preliminary Interpretation of the Tectonic Stability of the Reference Repository Location, Cold Creek Syncline, Hanford Site: RHO-BWST-19 p, Rockwell Hanford Operations, Richland, Washington.

Diller, J.S., 1896, A geological reconnaissance in northwest Oregon: United States Geological Survey, 17 th Annual Report, part 3, p. 441-520.

Dobrin, M.B., 1960, Introduction to geophysical prospecting: New York, McGraw Hill Book Company; 1976, 3rded. 
Drake, A., 1982, Tectonic evolution of the Oregon continental margin: Oregon Geology, v. 44, no. 2, p. $15-21$.

Felts, W.M., 1939a, A granodiorite stock in the Cascade Mountians of southwestern Washington: Ohio Jour. of Sci., v. 39, no. 6, p. 297-316.

Felts, W.M., 1939b, Keechelus andesitic lava flows of Washington in southward extension: Pan-Am. Geologist, v. 71 , no. 4, p. 294-296.

Hammond, P.E., 1980, Reconnaissance geologic map and crosssections of the southern Cascade Range: Geology Department, Portland State University, Portland Oregon.

Hass, N., 1982, A geophysical investigation of the nothwest extension of the Portland Hills Fault: unpublished master's thesis, Portland State University, Portland Oregon.

Hodge, E.T., 1933, Age of the Columbia River and lower canyon (Abst.): Pan-Am Geologist., v. 58, no. 1, p. 70 .

Hoffstetter, W.H., 1984, Geology of the Portland Well Field: Oregon Geology, v. 46, no. 6 .

Hogenson, G.M., and Foxworthy, B.L., 1965, Ground water in the East Portland Area, Oregon: United States Geological Survey Water Supply Paper 1793.

Jones, T.D., 1977, Analysis of a gravity traverse south of Portland, Oregon: unpublished B.S. thesis, Portland State University, Portland, Oregon.

Magill, J., and Cox, A., 1980, Tectonic rotation of the western Oregon Cascades: Oregon Department of Geology and Mineral Industries, special paper 10. 
Magil1, J., Cox, A., and Duncan, R., 1981, Tillamook Volcanic Series; Furthur evidence for tectonic rotation of the Oregon Coast Range: Journal of Geophysical Research, v. 86, no. 4, p. 2953-2970.

Mundorff, M., 1964, Clark County Aquifers: United States Geological Survey Water Supply Paper 1600.

Newton, V.C., Jr., 1969, Subsurface geology of the Lower Columbia and Willamette Basins, Oregon: Oregon

Department of Geology and Mineral Industries, Oil and Gas Investigation, No. 2 .

Perttu, R.K., 1976, Structural geology of the northeast quarter of the Dutchman Butte quadrangle, Oregon: Portland State University master's thesis, $60 \mathrm{p.}$, unpublished.

Perttu, J.D., 1980, An analysis of gravity surveys in the Portland Basin, Oregon: unpublished master's thesis, Portland State University, Portland, Oregon.

Reidel, S.P., Long, P.E., Myers, C.W., and Mase, J., 1982, New evidence for greater than $3.2 \mathrm{~km}$ of Columbia River Basalt beneath the central Columbia Plateau: EOS (American Geophysical Union Transactions), v. 63, p. 173 .

Simpson, R.W., and Cox, A.V., 1977, Paleomagnetic evidence for tectonic rotation of the Oregon Coast Range: Geology, v. 5, p. 585-589.

Skeels, D.C., 1963, An approximate solution of the problem of maximum depth in gravity interpretation: Geophysics, v. 28, p. 724-735.

Snavely, P.D. Jr., Macleod, N.S., and Wagner, H.C., 1968, Tholeiitic and alkalic basalts of the Eocene Siletz River Volcanics, Oregon Coast Range: American Journal of Science, v. 266, p. 454-481.

Snave1y, P.D., Jr., and Wagner, H.C., 1963, Tertiary geologic history of western Oregon and Washington: Washington Division of Mines and Geology, R.I. 22 . 
Snavely, P.D., Jr., and Wagner, H.C., 1964, Geologic sketch of northwest Oregon: United States Geological Survey Bulletin, no. $1181-M$.

Telford, W.M., Geldart, L.P., Sheriff, R.S., and Keys, D.A., 1976, Applied geophysics: Cambridge, Cambridge

University Press.

Thiruvathukal, J.V., Berg, J.W., and Heinrichs, D.F., 1970, Regional gravity of Oregon: Geological Society of America Bulletin, v. 81, no. 3, p. 725-738.

Tolan, T.L., 1982, The stratigraphic relationships of the Columbia River Basalt Group in the lower Columbia River Gorge of Oregon and Washington: unpublished master's thesis, Portland State University, Portland, Oregon.

Tolan, T.L., and Beeson, M.H., 1984, Intercanyon flows of the Columbia River Basalt Group in the lower Columbia River Gorge and their relationship to the Troutdale Formation: Geological Society of America Bulletin, v. 95 , no. 4, p. 463-467.

Tolan, T.L., Beeson, M.H., and Vogt, B., 1984, Exploring the Neogene history of the Columbia River; Discussion and field trip guide to the Columbia River Gorge: Oregon Geology, v. 46, no. 8 .

Treasher, R.C., 1942, Geologic history of the Portland area: Oregon Department of Geology and Mineral Industries Short Paper 7, 10p., geol. map.

Trimble, D.E., 1963, Geology of the Portland, Oregon and adjacent areas: United States Geological Survey Bulletin, 1119, map scale $1: 62,500$.

Wilkenson, W.D., Lowry, W.D., and Baldwin, E.M., 1946 , Geology of the St. Helens Quadrangle, Oregon: Oregon Department of Geology and Mineral Industries Bulletin no. 31 . 


\section{APPENDIX A}

\section{COMPUTER PROGRAMS}

1) WINGS1- 1984 - Theodolite survey reduction, organization and plotting.

2) PRINBEST - 1985 - Selective search and organization of northwest gravity data base.

3) LOCAL - 1985 - Parameter determination for local gravity stations needed by modeling programs.

4) REGIONAL - 1985 - Parameter determination for regional gravity stations needed by modeling programs.

5) FREENEW(FREEAIR) - Ta1wani 1969, modified by others 1985 - Free air gravity modeling program. 
PROGRA: HINGSI

Stever, A Davis

$7 / 11 / 84$

THIS PROGRPY HIL REULE RPU THEODOLITE SURVEY DATA TO EEVATIOUS

AW HORIZONTR ANGLE CORRECTIENS HITH ONY MINDE ADDITIOWS TO

THE OFIEINR: DATR.

THESE ADDITIOWS ARE MLET(I), CODEI (I) AND CODES(I)

- WERE...

MRT(I) $=1$ IF A FRL STADIA INTERCEPT IS LEED

2 IF A HALF - - -

CODEI- KEANS STADIA READING IS TOF OR BOTTOW STADIA HAIR PEADING

CODE- FEANS STADIA READINE IS MIDDIE STRDIA HAIR READING

CERTAIN CONOITIOAS WUST BE GET TO INSURE RLL CONEIDENCE IN

TTE OUTPS

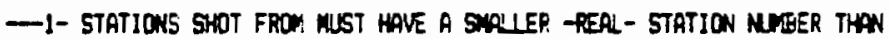

THE STAIION SWOT TO..ACOEPT- BACK SHOTS FDR TIE IN

PURPOSES MAY BE GRERTER TO LESSER PROUIDED THEY DCOUR

OEE AT A TIKE

-E- SUBTRRETION THROUGH 360 DEGREES IS NOT ALIONED. EXATPE

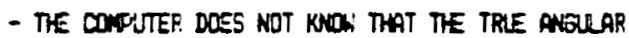

DIFFERANCE EETHEEN TWO SHOTS IS 3EL-! $1=20$ DEGRES RATHER

340 DESRESE.

-3- THE FIRST ENTRY OF THE DRTA FILE CAN NOT BE A EAOK SIETT.

$\rightarrow$ - HECKSIEHTS CAN BE WADE TO GASE STATIOWS DEY.

-5- THE STATION USED IN PART 2 OF THIS PROBRPM FOR WIIOH LATITUE ANO LONGINDE ARE RLREADY KNOW CON NOT RE THE FIRST STATION OF THE SURVE. IT WUST APPEAR IN ARRAY TD(I)

AS A FORESIETT- SINCE EROXSIGTSS ARE DISCARDED IN THIS PORTION OF TEE PRDGRAY SURVEY AN EXTRA FOPESIET TO THIS STATION IF NECOESAPY.

$\rightarrow$ PRAGRAM CONTRO VRLLES UST BE SPECIFIED IN TIE FIRST READ STATEMTT...

THEY ARE.

MWT- THE MUEER OF LINES OF DATA OCOURING IN RERD 101 OR READ IOE

K- THE STADIA INTERVR FRTTOR

C- THE STADIA CONSTANT

ORRENT- TIE PDSITIOW MUMEER OF TFE BENCHAROK IN ARRAY-TO FLLS 1

BEELV THE ERVATION OF THE RENCHADKK

OPTIOH- ANY NEGATIVE SINGE DIGIT HIL CODOSE THE SIFLIFIED PROERAY ANY POSITIVE ENSAEES THE LAT \& LONE FART OF THE PROGRPA ALSO - UNTIL PARTI RLNS AS DESIREI PART2 
INTEGER MUME, FLA6 (200), CODE 1 (200), CODEE (200), J

DOUELE PRECISION ID (29)

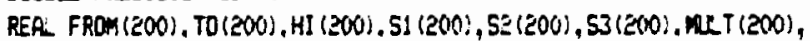

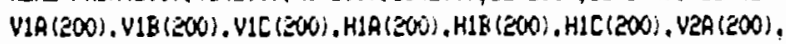

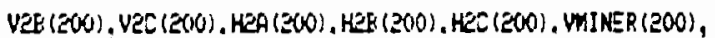

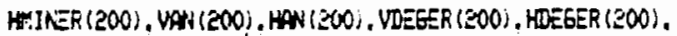
H. DEGROT (200), ELETO (EOO) , DELEV (200), DIF, EEELEV, FELETO (2010),

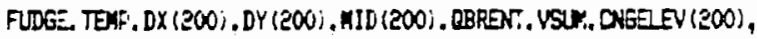
DYT (EOO). DELEVT (ZOO), VANT (200), SIEN (EOO). MINSLM (200), REFDIR, HDX (200), HDY (200), XVALLE (200), YYRLLE (ZOO), HANCOR (200), HSUH. AOJUSTER(ENO). CONPTAN (200). LAT (200). LONG (ECO), LATDOR. LONCDF, ORILAT, ORILOW. PIE, THOPIE, FANGLE, ANOLE, FRSDIR, PQE, FRS. COFPTAN DATA (ID (I) , I=1, Z9) / DEGREFS', 'HOPZNTRL', 'ERROP', ' WJMUTES', 'VERTICR', ' 'ANEE', 'FRON', ' TO', 'RADIANE', 'DISTANEE', 'MIDD, 'E', 'STADIR', ' VRLLE', ' CHOWEE', 'EL LATION', 'FINGL', 'RRR (TO)', 'TEPRARY', 'ROTATION' , 'STATIOW', 'SHOT', 'SUW', ' CORRECTD', 'DX', 'DY', ' XVRLLES, ' YWRLLE', 'LAT', 'LONE' / READ (E. LOO) NULE, K. C. OBRENT, BNEEV. OPTION

100 FOKAAT (IJ, FE. 1, F3. 1, FE, 1, FE. 3, F4.0) WRITE (6. 211)

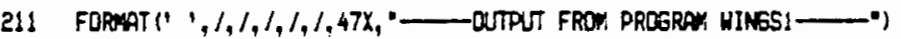
WRITE (6, 215$)$

215 FORMATI" $, 1,1,1, "-$-HARNINE $\rightarrow$-CHECK CONOITIONS IN PRDGRPW", 1 , I"COMENT CARDS - CERTAIN CONOITIONE WUST BE NET"., $/, 1,1,1$,

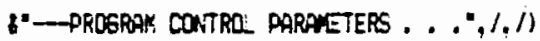

WRITE (6. 200)NLUE, K, C. QERENT, BFEEV

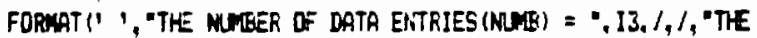

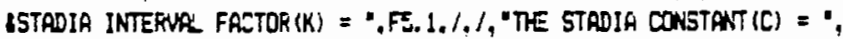

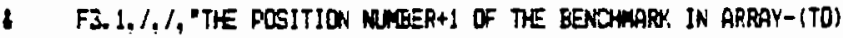

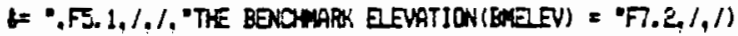

DO $90 I=1$, HWH READ (5, 1(1) FRON(I), HI (I), TO(I), MLT (I), 5! (I), CODEI (I), SE(I),

1 CODER (1)

101 FORMAT (FE. 1, FE. 3, FE, 1, FE. 0, FE, 3, 11, FE 3, 11)

90 CoNTIME

DO $89 I=1$, MUIE

RERD (5, 102) VIA(I), VIB(I), VIC(I), HIA(I), HIB(I), HIC(I), VEA(I),

1 VaB(I).VECII),HER(I),HEB(I), HECII)

102 FORWAT (1LES.0)

89 CONTIME

Do $91 \mathrm{I}=1, \mathrm{M} M \mathrm{~T}$

SIEN(I) $=\{$ VIC $(I)+V Z C(I))-60.0$

MINSLF(I) $=$ V1E(I) + YZE(I)

$V I E(I)=V 1 E(I)+(V I C(I) / 60.0)$

VEF(I) $=V$ VES (I) $+(\mathrm{V} 2 C(I) / 60.0)$

MIKER (I) $=\{$ WIE $(I)+V 3 E(I))-60.0$ 
$H I B(I)=H I B(I)+(H I C(I) / 60.0)$

$H 2 F(I)=H 28(I)+(H 2 C(I) / 60.0)$

HWIER(I) $=\mathrm{HIE}(I)+$ HeS (I)

$V 1 A(I)=V I A(I)+(V S F(I) / 60.0)$

$\mathrm{VEA}(I)=\mathrm{VRR}(I)+(\mathrm{V} E(I) / 60.0)$

VDEGER (I) $=$ ALS $(190.0-V 1 A(I))-\{$ V29 (I) -270.01$)$

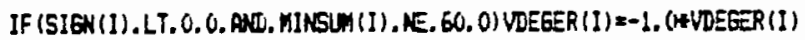

WN(I) $=(190.0-V 1 A(I))+(V B Q(I)-270.0)) / 2.0$

$H I A(I)=H I A(I)+(H I B(I) / 60.0)$

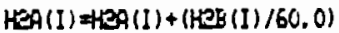

IF (HIA(I).LT. HEA (I) 60 TO

IF (HEA(I).LT. HIA (I) 60 TO 5

$4 \quad H 2 A(1)=12 R(1)-180.0$

HDEEER $(1)=11 A(1)+$ HOA (I)

$\operatorname{RAN}(I)=($ (HIA $(I)-($ MDEER $(I) / 2.0))+($ HEA $(I)-($ DEEEER $(I) / \Xi 0))) / 2.0$

$H 39(I)=(H E A(1)+180.0)+($ HEEER $(1) / 2.0)$

60 706

5 $H I A(I)=H I A(I)-180.0$

HDEEER (I) $=H 1$ A (I) - HEA (I)

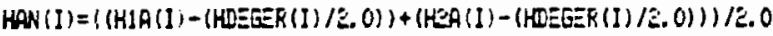

$H I R(I)=(H I A(I)+180.0)+(H D E E E R(I) / 2.0)$

$6 \quad H S(n=4 S U M+1 T E E E R(I)$

$S 3(I)=(51)(I)-52(I))$ HDL $T(I)$

91 CONTIME

URITE(6. 212)

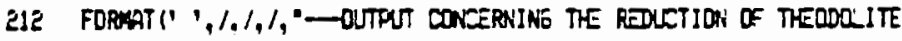

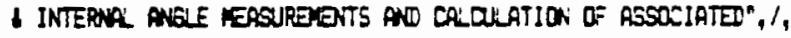

1 "ERRORS ...")

WRITE(6. 201) ID (3), ID(20), ID (20), ID(5), ID(2), ID (5), ID (2), ID (23),

- ID(21),ID(21).ID(4),ID(4),ID(1),ID(5),ID(1),ID(2), ID (7), ID (8),

- ID(3),ID(3),ID(3),ID(6), ID (3), ID (6)

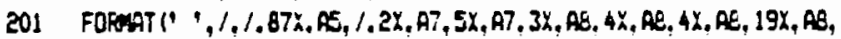

$14 X . A B, 1,2 X, A 4, B X, A 4,6 X, A B, 4 X, A E, 4 X, A B, 5 X, A B, 6 X, A E, 4 X, A B, 1$,

$12 X, A 4, B X, A E, 8 X, F E, 7 X, A E, 7 X, R E, B X, A E, 9 X, R E, 7 X, A 5)$

DO $991=1$, MXB

WRITE $(5,202)$ FRON(I), TO(I), MINER(I), HMINER (I), VDEGER (I), VAN(I),

1 MDEER (I), HIR(I)

202 FORWAT' ' $, F 7.3,5 x, F 7.3,5 x, F 7.4,5 x, 77.4,5 x, F 7,4,5 x, F B .4,5 x$,

$(F), 4,5 X, F B .4)$

99 CONTIME

WRITE (6. 224)HSM

224 FOFWAT'' 11.1, "TEE TOTAL HORIZONTR ERROR FOR THE LEYGTH

6 OF THIS LINE IS $=$ ",2X,F8.4)

DO $971=1$, NUNA

$\operatorname{VAN}(1)=\operatorname{VaN}(1) 60.0174533$

$D X(I)=(((K+53(I))+\cos (\operatorname{VAN}(J)))+C)+\cos (\operatorname{DN}(I))$

DY $(I)=(($ (K+SJ $(I))+\operatorname{SIN}($ VAN $(I)))+\operatorname{COS}($ VAR $(I)))+(C+(\operatorname{SIN}($ VaN $(I))))$

97 COTINAE

FUE (1) $=0.0$

TE:P $=0.0$

2 DO gE $i=1$, MUAB

FLAG $(I)=F L A G(I)+1$

IF (FLAE(I). EQ. NQME) ED TO 3

IF (FROM (I+1). ES. FRON(I) 60 TO 1

DESROT $(I)=$ TEP

TETr=HAN $(I+1)$ HAW (I)

EO 1092

1 DEGRTT (I) =TET

gE CONTINE

Do $1051=1$, Mun 
IF (FROM (I) . GT. TO (I) ) DEEROT (I) =DEGRDT (I) +DEGROT (I-1)

IF (FROM (I) .LT. TO (I) ) DEGROT (I) =DEEROT (I-1)

HONCOR (I) =HIO (1) -DEEROT (I)

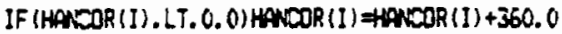

IF (HOWCOR (I) . 6T. 360. 0) HANCOR (I) =HANCOR (I) - -350.0

106 CONTIME

I DO $95 \mathrm{i}=1$, MUN

IF (CONEI (1).ER. 2)MID (I) $=51(1)$

IF (CODE2 (1). EQ. E) MID (I) $=52$ (1)

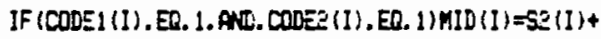

$1 \quad($ (SI $(1)-52(1)) / C .0)$

93 CONTINE

ELETO(1) $=0.0$

FDEE $=0.0$

DO $951=\$$. NMTH

DEEV (I) $=D Y(I)+H I(I) \rightarrow I D(I)$

IF (FROM(I) . GT. TO(I)) FDEE $=$ ELFTO(I)

ELETO(I+1) =DEREV (I) +FUDEE

95 CONTINE

WRITE (6. 209)

209 FOROAT $1,1,1,1, \cdot$-INTERUEDIRTE FIEURES USED IN DETERMINATION

6 OF FINA VRILES...,

WRITE (E, ZU3) ID (20), ID (20), ID(5), ID (11), ID(21), ID(21), ID(6),

1 ID (2), ID(E), ID (12), ID (14), ID (7), ID (8), ID (9), ID (10), ID (10),

1 ID(13), 1D!15)

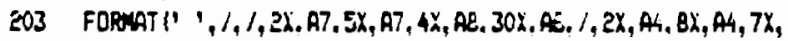

1 AE. 10X,AS, 4X,AE. 3X.AE, 4X,AE, I.2X,A4, 8X,AE, 9X,A7, BX,AE, 4X,

1 AE. 3\%,AE. SX.AST

DO $9 E \mathrm{I}=\mathrm{i}$. NLUTE

URITE (E, 2CA)FRCM(1), TO(1), VAN(1), DX (1), DY(I), MID (I), DELFV(1)

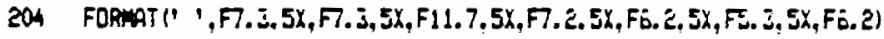

98 CONTINE

DIF $=$ BRELIEV EIETOLOBREMT)

DO SO $1=1 . M M T+1$

FELETO(I) =ELETO(I) +DIF

96 CONTIME

HRITE 6,207$)$ DIF

207 FORAAT(' $, 1,1,1$, 'THE ElEVATION CORRECTIDN FARTOR(DIF) $=\cdot, F 7.2$,

$1 \quad 1.11$

WRITE(E, E10)

210 FORMAT' ' $, 1,1,1$, "-TTE FINR VRLUES - DEgREES OF ROTATION

8 ARE CDRRECT IF 360 DEGPEE CONDITION IS NOT VICLATED . . .",

HRITE $(6,205) I D(19), I D(20)$, ID (20), ID(16), ID (18), ID (23), ID(21),

- ID(21), ID(15), ID(15), ID(2), ID (1), ID(7), ID (8), ID(17), ID(17),

$1 \quad 1 D(6), 10(19)$

205 FOAMATY' ' $1,1,51 X, A B, 1,2 X, A 7,5 X, A 7,5 X, A E, 5 X, A B, 3 X, A B, 1,2 X$,

$1 A 4, B X, A 4, B X, A E, 6 X, A 5,3 X, A C, 5 X, A 7,1,2 X, A 4, B X, R 2,10 X, A 7,7 X, A 7$,

- $\quad 4 X, A E, B X, A B)$

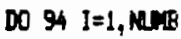

$j=I+1$

MRITE (E. EOE)FRDM (I), TB(I), FEETO (J), ELETO(J), HANCOR (I), DEERDT (I)

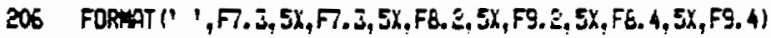

94 CONTINE

WRITE(E. 221)ID(20), ID(20), ID (23), ID (21), ID(21), ID(3),

1. $1 D(15), I D(7), I D(8), 1 D(15), 1 D(17)$

221 FORMAT" $1,1,1,1$, - VERTICAL COMTKOL SECTION- CHANGES IN

LELEVGTION DUE TO INGTRLMENT AND/OR HUMAN ERPOR...",/,

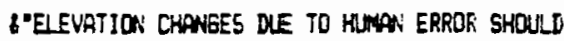

6 BE BaDOW ANT CORTRIEUTE NO",I. "SIENIFICANT

\& RESIDUAL ... HOWEVEF - INSTRUMENT ERROR 
6 SHORI RESUR IN ". "OCNGistent fOSITIVE

+ OR NEGATIVE ELEVATION CMANGE5.. IT

- IS ACOETABLE TO DISTRIEUTE THIS ERROR. . " $/, 1,1$,

$1 \quad 2 X, A 7,5 X, A 7,20 X, A E, I, 1 X, A 4,8 X, A 4,10 X, A 5, B X, A B, J, 1 X, A 4,8 X$,

1 AE. 1 (XX,AE, SX,A7)

DD $86 j=1$. NUMR

VAN (I) $=$ VAN (I) $/ 0.0174535$

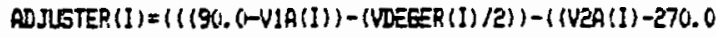

( )-(VDEER $(1) / 2)))$

VANT (I) = VAN (I) -AL JUSTER (I)

VAT (I) =VANT (I) $* 0.0174535$

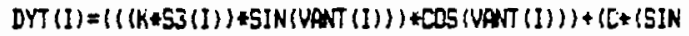

\&(VA) (I) $)$ )

DELEVT(I) =DYT (I) +HI (I) HID (I)

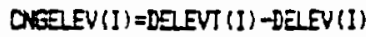

IF (FROA (I) , EQ. TO(I-1) USL USUA+CNEELEV(I)

BE CONTINE

ELETO $(1)=0.0$

FUDSE $=0.0$

DD $105 \mathrm{I}=1, \mathrm{MME}$

IF (FROM (I) . GT. TO (1)) FUDEE=ELETO(I)

ELETO $(I+1)=$ DELEVT (I) +FDSE

103

CONTINE

DIF $=$ GELEV EUETO (OBRENT)

DO $104 \mathrm{~J}=1$. $\mathrm{MUF}+\mathrm{F}+1$

FELETO $(I)=E L E T O(I)+D I F$

104 CONTIME

DO $105 \mathrm{~J}=1, \mathrm{~N}, \mathrm{H}$

$I=I+1$

WRITE (E. 20O)FROM(I), TO(1), CAEEEV(I), FE] ETO(3)

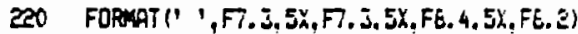

105 CONTINE

URITE $\{6.223)$ USUM

223 FORHAT!' ',, 1, "THE TOTA VERICR. ERROF, FOR THE LEROTH DF THIS

L LINE IS = ".2X.FE.4)

XEALEVRL $=0.0$

YEASEVA $=0.0$

REFDIK $=180.0$

DO $107 \mathrm{I}=1$. MUNB

IF (FRDH (I). GT. TO(I))ED TO 107

A=REFDIF + ANCOR(I)

$A=A+(1.0174533$

HOX $(1)=D X(1)+\operatorname{CDS}(A)$

$\operatorname{HOY}(I)=D X(1) * S I N(A)$

XVLIE(I) =XEASEVR: + OXX(I)

WRUE (I) = YEASEVPI +DY (I)

IF (FROM (I+1). RE. FROH (I) ) XBASEVRL =XBASEVR + +DX (I)

IF (FROM (I+1) . NE. FRON (I) ) YEASEYFL = YEASEVR HDY (I)

107 CONTINE

WRITE $(E, 231)$

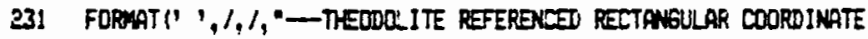

( DATR - AL STATIONS...", /,

WRITE (E, 205) ID (20), ID(20), ID(21), ID (21), ID(7), ID(8),

1 ID(24), ID(25), ID(26), ID(27)

225 FORYAT!' $1,1,1,2 X, A 7,5 X, A 7,1,2 X, A 4, B X, A 4,1,2 X, A 4, A X, A^{2}$,

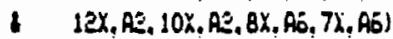

DO $108 \mathrm{~g} I=1 . \mathrm{N}(\mathrm{M})$

IF (FROAII), GT, TO(I)) 60 TO 108

WRITE (E, JEE)FROM (I), TO (I), KDX (I), KDY (I), XVALUE (I), WRUUE (I)

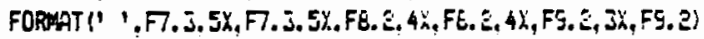


109 CONTINLE

URITE (E. 230)

230 FORWAT" ' $1,1,1$, "6RAFH AL OF DART OF THE REOVE DATA

1", "ULE TTE - EXATT-

\& SCALE OF YOUF MAF, MATCH YQUR GRAPH TO THE KNOMN SUIRVEY RDUTE.

\& FIND $A^{n}, 1$, "RELIARLE STATION AT AS GREAT A DISTANCE AE POSSIELE

6 FRON THE ORIGIN. DENDTE THIS STATION FRS- RERSURE TTE $X$ ANO $Y$

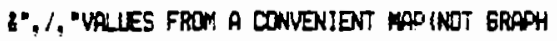

b) MOJOR AXIS(0,90,180,270) TO THE

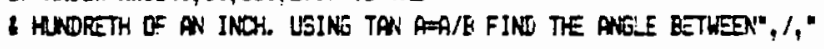

ITEE AZIMUTH TKROUSH FRE AN THIS KNJOR AXIS. AOD OF SUBTRAT THIS

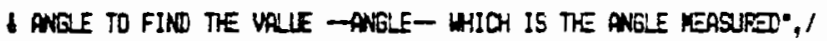

¿. "FROT IEFIL - CLOCKLISE - TO AZIMUTH FRS. THIS IS A

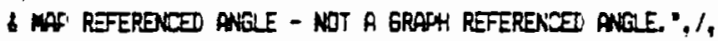

1"- ENTER THE FQLLOWINE WALLES IN RERO $(5,109)^{\circ}, 1$,

1"- AUELE. .. AS ABOVE", $/$,

1"- LATCOR... THE VRLLE IN FEE DF ONE DEGREE OF LATITUDE AT

\& THIS LATITUIDE. $\%$

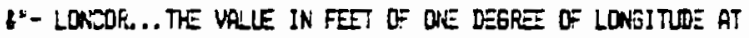

\& THIS LATITIE". $\%$

$E^{2}$ - FOE... THE FORESIETI FOSITION IN ARRAY TO(1) A F STATIDR WERE

1 LATITUDE AND LONGITLDE ARE KHOW:"./,

8" - ORILON... LONGITLEE (DECIMALIO= STATION USED FOR FOS",, ,

:- ORILAT... LATITUE (DECIML) OF STATION USE FOF POS")

URITE (6, 232)

23 FOPWAT" ', "- FRS... THE FORESIGT (NDT BACKSIGHT) POSITION

1 IN ARRAY TO(I) OF A STATION WHICH YOU ARE

- CONEIDEAT IS LOCATEI RCURATELY ON YOUR GRAPH.")

IF IDOTIOK. LT. 0.0)60 TO 15

READ (E, 109) ANELE, LATCOR, LOADOF, ROE, ORILAT, ORILDK, FRS

109 FOPWAT (FE. 4,F10.Z, F10.S,F4.0.FE.4,FE.4, F4.0)

$P I E=21416$

TUOPIE $=2.0+5.1416$

ANGLE $=$ ANGLE $*(1.017453$

REDIR=REPDIR +0.0174533

IF (XWRLLE (FRS) , 6T. 0. (1. ANO. YWRLLE IFRS) . 6T. 0. 0)FRSDIF=REFDIK

8- (ATAN (YVRLIE (FRS) /XYRLLE (FRS)))

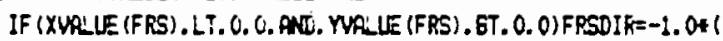

LATAN (YUALLE (FPS) / XVRLE (FRS)))

IF (XUALIE (FRS) . GT. O. O. ANO. WRLLE (FRS) . LT. O. O)FRSOIK=REDDIR

I- (ATAN (YVALUE (FRS) / XVALLE (FRE)))

IF (XVALLE (FRS) , LT, O. O AND. WNLLE (FRS) , LT , O. O) FFSDIK=TWDFIE

\&-(ATAN (YVLLUE (FRS) / XWALLE (FRS)))

$00110 I=1, M N B$

IF (FROM(I). GT. TO(I)) 60 TO 110

IF (XUALUE(I), GT, 0, 0, ANO. YUALUE(I), GT. 0.0) CONFTAN(I) =ATAN

I (YNALUE (I) /XVQLUE (I))

IF (XVALUE (I) .LT. 0.0.ANO. YALUE(I), 6T,0.0)CONPTAN(I) $=$ PIE

I+ (RTANITVRLLE(I)/XYLLUE(I)))

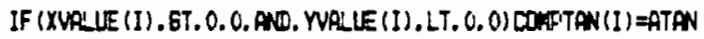

I (YALLE(I)/XVALE(I))

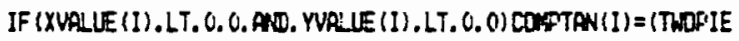

(- (ATAN (YVLLLE(I)/XVAUE(I))))

FANGLE =ANGLE $+($ (REFDIF-FRSDIR) - (COFPTAN (I)))

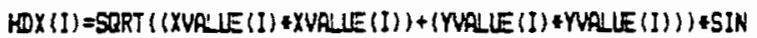

(FANELE)

HDY (I) = SORT ( (XVALLE (I) *XVALUE (I) ) + YVRLUE (I) +YVRLUE (I)) )+COS

\&(FANGLE)

110 CONTINUE

DO 211 I $=505$, NUME 
LAT (1) $=$ OFILAT + ( (HDY (I) +DY (FOS) ) /LATCOR )

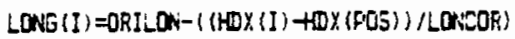

111 COITINLE

IF (FO5. EG. 1. O) 6R TO 7

Do $1121=1, \mathrm{POS}+1$

$J=F D=-1$

LAT (J) =ORILAT+ ! (HDY (J) +DY (FOS) ) / LATCOR)

LONG (J) =ORILON- ( INDX (J) +DDX (FOS) ) LOKCOR)

112 CONTIML

7 URITE $(6,240)$

240 FORIATI' ', $/, 1$, "_INAL LATITIDE \& LONEITLE WITH WF'

- REFERENEL RECTANGLAP COOPDINATE DATC- AL: STATIONE...")

WRITE $(0,227)$ ID (E) , ID (2B), ID (39), ID (2E), ID (27)

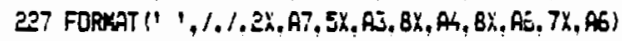

DO 113 I=1. NUME

IF (FROM(I). GT. TO(I)) 50 TO 113

WRITE (E. 2EE) TO (I), LAT (I), LONE (I), HDXII), HOY (I)

113 CONINLE

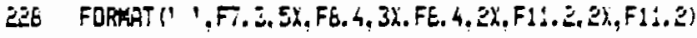

I5 URITE UE. 29:;

2ES FORAAT(" ',, 1, "TERMINGTIO: OF QUTFUT FILE")

STOF

END 
$\$ \$$

S: IDENT: PESOHOND.DAVIS S

\$:SELECT:LIBRARY/SEL/FORT

C PROEROH FRINEEST

C $3 / 3 / 65$

C BY STEVEN A DAVIS

C

C PRINEEST HIL SEARCH ANY WINDOW OF THE BASE GRAVITY DATR OF

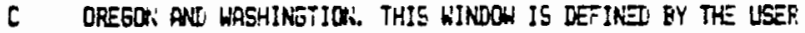

C AE W ACLEPTRELE CUTOFF ZOEE ON EITHEF SIDE OF HIS RLEIONR

C LINE EEYOND WHCH E WIL NOT MIGRATE ANY STRTIONS. ST W

C AREITRAPY COORDINATE AYES HITH TIE ORIGIN WEST OF THE WESTERN

C ENO OF YOUR REGIONOL LINE.

C FINO THE INTERSECTION OF YOUR REEIONR LINE WITH TVE Y AXIS

C

AND DFFINE THE OUTDF LIMITS WITH THO Y INTEROEPTS.

THE FOLONINE SPECIFIC DATA IS NEEIEL...

KMDESLAT = VIILOHETERS FEP DEEREE OF LATITLDE AT YOUR LATITUDE.

LATORG = LATITUDE OF THE OPIGIR! FROH WHICH EOHE, ETLD AND LOHORS ARE REFERENCED. HTHIS IS NOT THE SAWE LATORG

AE HILL APFEAR IN REGIONRL OR LOCALH+

RE = RADIUS OF THE EARTH (KM)

LONORL = LOAGITUDE OF Y AXIS DF COOROINATE SYSTEY- RT THE ORIGIN-

EONE $=Y$ INTERCEPT OF NORTEERL Y CITOFF 2DNE. THIS ASSUNES LATORE

IS TREATEU AE ZERO. KEX. LATORE $=45.0$ AW BOAE IS 44.95 THEH GOUE IS -.05)

ETULL AE BOKE RBOVE EST IS SOUTHERLY CUTOF BOUKDARY.

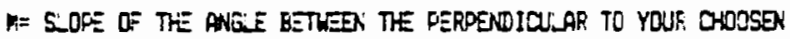
LIE OF LONGITLUE (LONORE) ANO YOUR REGIONR LINE TEASURED AT

THE INTEPSEFT OF THE REGIDNA: 1

INE.

ALSO- BE CERTAIN TO CHANEE :IKITS IN THE FIRST LOSICR IF STATERET.

RLTHOUEH THE PRESENT FORY OF PRINESST MAY HAVE LIMITATIONS

IT CAY EE EASULY WODIFIEU TO FIT SPEEIFIC NEEDS. SUCH NEEDS

MIEHT EE NEGATIVE SLOPDD LINES ETC. GOOD LUCY.

RER: BORE, ETID. K. Z. LATORE, LONDRG, LATCLDNE, ML, Y, RE, KNDEGLAT

KMDEGLAT $=111.14075$

LATORE $=45.50$

PE $=537 \bar{C} .4$

LONORE $=133.7052$

EONE $=0.0848138$

BTWO=0.01458545

$n=0.0$

DO $30 \mathrm{~J}=1,15214$

REAO (OE, 1O) $, B, C, D, E, F, E, H, F, O$

10 FORWAT IEA, FIO. 4, FG, 4, FE. Z, FG. Z, FE. Z, FE. E, FB. E, F11.3)

IF IC. 6T. 123. 709E. OR. C. LT, 12:.0000. OF. L. GT. 45.6000. OF. D. LT.

445. $5(X 0) 60$ TO 30

$\mathrm{D}=\mathrm{D} * 0.0174535$

LATQLONE $=(12 *$ \{3. $1417 *(R E *(\operatorname{COS}(D)))) / 360.0) /$ KWDEELAT

$\mathrm{I}=\mathrm{D} / 0.01745 \mathrm{si3}$

$M:=$ OES ( (LLONORE-C) +LATOLONO) $K M)$

$Y=I$ LATORG

$Z=Y-M X$

IF (2.6T. EOHE. OE. 2.LT.ETH]) G[T TO 30 
WRITE (OE, ZO)G, E, E. D, E.F.G.H.F.Q

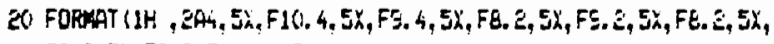
IFE. Z, 5X,FE. $2,5 \dot{n}, F 11.3)$

HRITE(IE, 25)A, B, C. D, E, F, G, H,F, Q

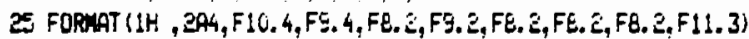

3.) CONTINLE

STOF

END

5:SELECT:LIBRARY/SE/EXEC

T:LIMITS: 5, , , 6K

\$:MGOE:REAL ONLY HO934 $\mathrm{K}=$ GRAVE

5: TAFES:OE. TIDU, , HOF34

\$:FILE: IE, , IL, REW, USESDATA

\$:SYSOUT:OE, ORE

$\triangle:$ ENOJOE 
PROGRAT: LOCR

FY STEVEN A DAYIS

$3 / 20 / 85$

THIS FROGRAH WILL PROCESS DATA FROM YOUR. LOCA LINE. THE DATA IS

HOWUIII IR SLEH A WAY AE TO FUT YOUR. LOCA LINE IN PERSFECTIVE

HITH YOUP REGIONG LINE. IT REOUIRES THE SATE SHECIFIC DATA

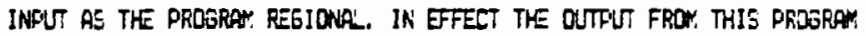

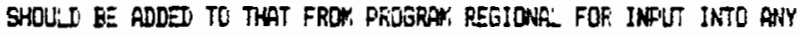

OF THE GRAYIT' FROARAHE HERE SUCH DATA IS REQUIRED.

DUTFU HIL CONEIST OF..

1-ORDERET INFU EY LONSITIEE

Z-COLOCATEI HORIZONTR DISTARES,

PRDEETI DISTANESS AU EEVRTIOH

IN KILONETERS.

SFECIFIC INFUT CONEISTS DF...

1-KMDELAT=KILOVETERE FER DEGPII OF LATITUDE AT YOUP. LATITUDE

E-LATORE=LATITUEE OF BEGINNINE OF PEOIONGL LINE

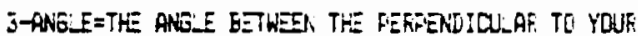

CHOOSES LINE OF LONEITUDE LLONDES; ANC YOUF. REGIONFL

LIRE. MEASUPEI RT THE ORIGIN.

4-LONORG=TEE LONGITUDE OF THE BEGINNINE OF YOUF. REGIONL LINE.

ENA=THE NUMEEF OF LINES OF DATA IN DATA FILE.

A DATA FILE RUST BE CONSTRLETES HHICH JKELUDES...

1-STATIOK NUMEER

ZELEVATION IN FET

j-LONGITUE

4-LATITULE

SEE FORMGTHIO FOF: SYNTAX

RERL Y, X, HDST (400), PROJ $(4(0))$, DATA (4KO, 4), KKCEQLAT, LATQL ONE, Y, ANE,

1 ANQLE. C. TEMPO (400), LONORE, LATORE, F, TEKF (40\%, 4), RE

INTEGER FLAGD, N, K, FLAG

KMDES:AT $=111.14321$

LATORE $=44.91361$

RNE' $=3{ }^{\circ} .200936$

LONOKE $=125.3631$

$\mathrm{N}=32$

$R E=5378.4$

DO $891=1 . \mathrm{N}$

READ (2l, 10) (DATA $(I, J), J=1,4)$

10 FOFAST (FB. J,F $. \bar{Z}, F 10.4, F \cdot .4)$

B9 CONIINE

DO $91 \mathrm{I}=1 . \mathrm{N}$

IF (FLAE. EE. (N-1))60 TO ?

FLAE $=0$

DO $S O K=1, N-1$

IF (DATA $(K, 3)$. EE. DATA $(K+1,3)) 60$ TO 1

DO $\& \mathrm{~J}=1,4$

$\operatorname{TEAP}(K, J)=D A T A(K, J)$

$D A T A(K, J)=\operatorname{DATA}(K+1, J)$

DATA $(K+1, J)=T E M+(K, J)$

BE CONTINE

50 TO 90

1 FLAGFFLAG+1 


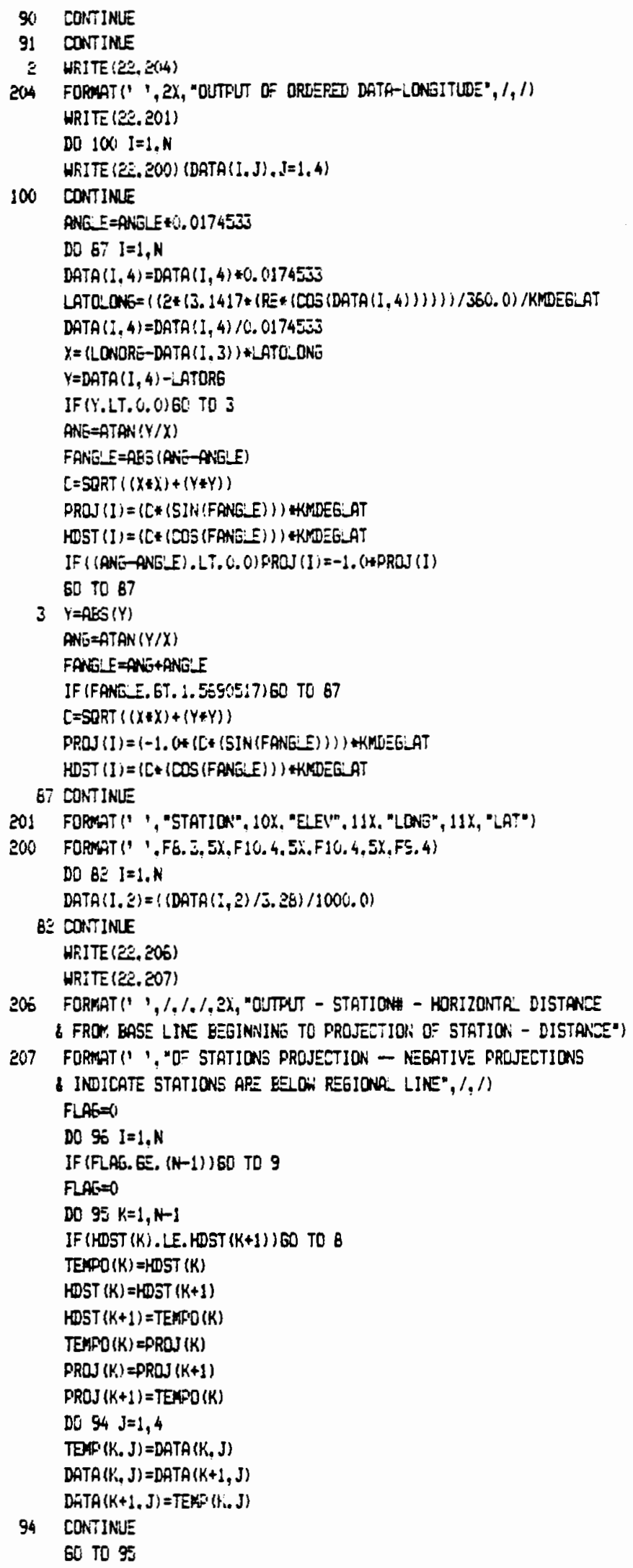


$F \perp A G=F L A G+1$

95 CONTINUE

So CONTINLE

9 HAITE $(2,203)$

DO $93 \mathrm{I}=1, \mathrm{~N}$

HRITE (2), ZOZ) DRTA (I, 1), DRTA (I, Z), HDST (I), PROJ (I)

95 CONTINLE

202 FDRMAT(' ',FE. Z, 5X,F11.4. 3 X.,F1(1. 4, 5X.,FE.4)

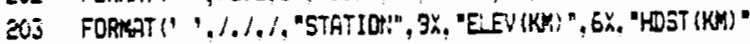

$8,4 x_{1}$ "FROJ DIST $\left.(K M) "\right)$

stor

END 
PROGRAT: REGIONAL

EY STEVEN A DAVIS

3/EO/EE

THIS FROERA: HILL PROCESS OUTFUT FROM FPDSRAF -FRINESST-

OUTH HIL CONSIS: 0:.

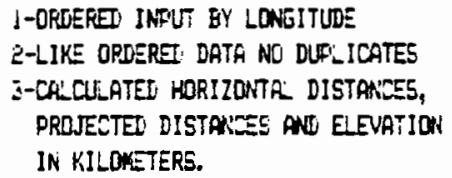

REA $Y, X$, HDST (400), FROJ (400), DATA (4OK. 10), KMDEE: AT, LATOLONE, K, ANE,

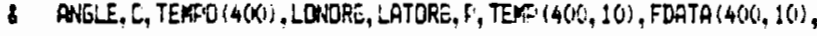

\& PE

IHTEEER. FLAGO, FLAGA, N. H, FLAG

K.DEGAT $=111.14075$

LATORE $=45.5446992$

ANG $E=0.0$

LONORE $=12 \overline{3} .7032$

$N=25$

$R E=0378.4$

DO $8 \mathrm{IS} \mathrm{I}=1, \mathrm{~N}$

RERD (21, 1 (1) (LATA (I, J), J $=1,10$ )

89 CONTINE

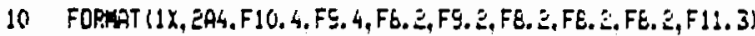

DO $91 J=1 . N$

IF (FLAT. E. $(k-1)) 60$ TO

FLAE $=0$

DO $90 \mathrm{~K}=1, \mathrm{~N}-1$

IF (DATACK. J). EE. DATA $(K+1,3)$ ) 60 TO 1

DO $Q E \mathrm{~J}=1.10$

TEMP' $(K, J)=$ DATA $(K, J)$

DATA $(K, J)=$ DATA $(K+1, j)$

DATA $(K+1, j)=\operatorname{TEMP}(k, j)$

88 COTINUE

\section{TO 90}

1 FLAE=FLAG+1

90 CONTINE

91 CONTIMU

2 HRITE(2), 204$)$

EKM FORYAT(' '. 2X, "OUTFUT OF ORDEREI DATG-LONGITUDE-INCLUDING

$($ DUFLICATES", 1,11

WRITE(E, Z01)

DO $100 \mathrm{I}=1 . \mathrm{N}$

HRITE (2:, EOO) (DATA(I, J), J I 1,10$)$

100 CONTINIE

Do $8 j \mathrm{j} J=1,10$

FDATA $(1, I)=$ DATA $(1, I)$

Q5 CONTINUE 


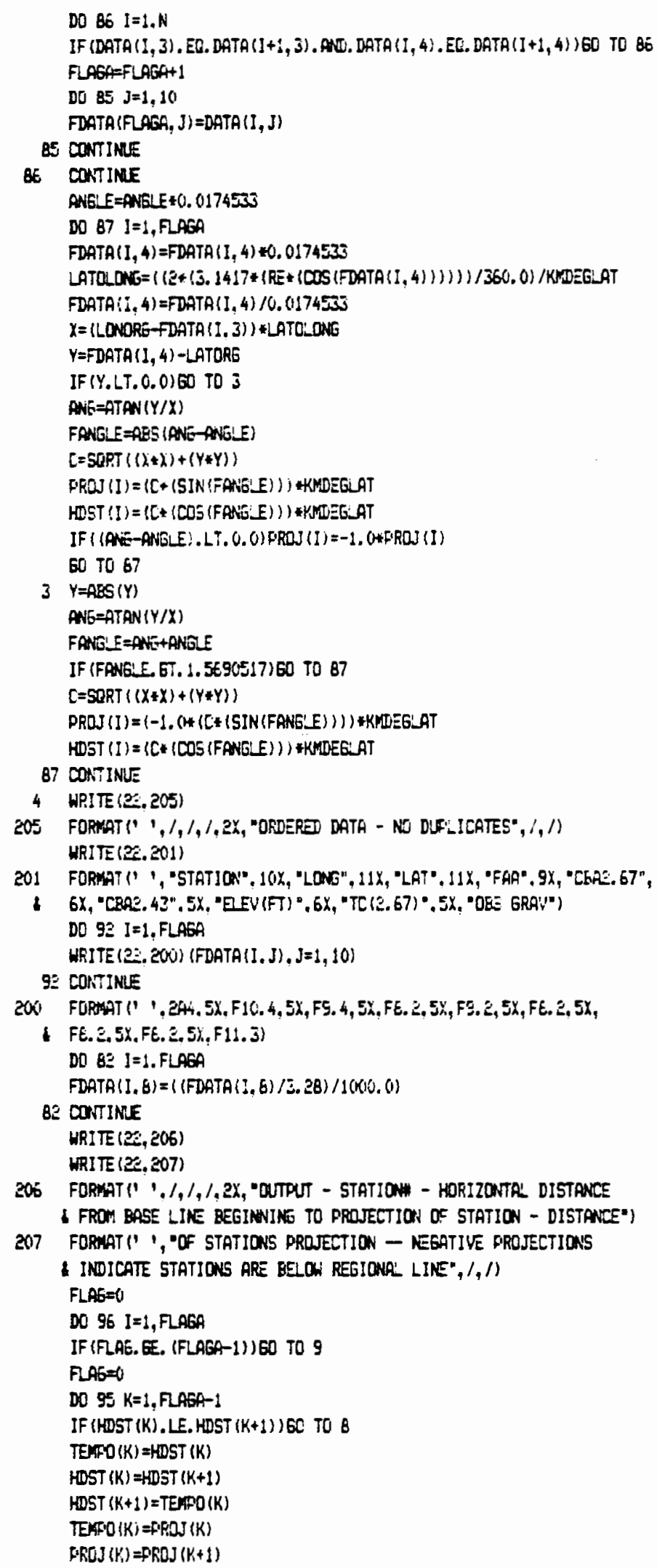


FROJ $(K+1)=$ TEMPO (K)

DO $94 \mathrm{~J}=1,10$

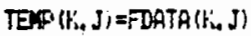

FDATA $(k, J)=$ ThATA $(K+1, j)$

FDATA $(K+!, J)=$ TEFF $(1, \ldots)$

94 CONTINE

60 TO 95

6 FLAE=FLAG+1

gS CONTINE

SO CONTINUE

9 HRITE (2), 203)

DC $53 \mathrm{I}=1, F L A G A$

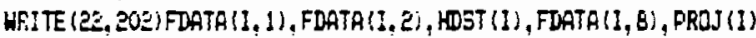

SE CONTINIE

202 FOF_AT(' ', 3A, 5X, F10,4,3X,F11, 4, 5X,FE. 4)

203 FORWTI" :, $/, 1,1$, "STATIQR", 3X, "HOST (KM) ", EX, "ELEV(KM)"

8 .4h, "FROJ DIST(KM)")

STO5

END 
FROGRAN FPEENEW

RODIFIEI BY R.C. HENKE 5/BS

KOJIFIEI EI STEVEN A. DAWIS $8 / 85$

FFEE AIF GRAVITY FIT PRDGRAM

THIS PKDGRAT, COMPUTES THE GRAUITATIONA ATTRAOTION ACROSS THE SURFGCE OF A RECTANGE COMFDSEU OF A MUEEF OF ARE:TRAPILY SHAPE ECOCKS.

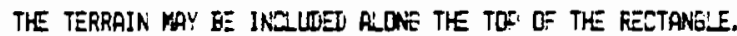
THE ORIGIN DE THE COOPJINATE SYSTE: IS IN THE UPFEF LEFT HAND CORNER DF THE RECTANGLE. I IS PCSITIVE DOWNGARDS. ALL DISTANCES ARE IR KY. THE PECTANGLE IS ORDINARILY EXTENOE AEDS JOK KY OA EITHER SIDE OF THE AREA OF INTEFESI IN ORDEF TO ELIHINATE EDGE EFFECTS.

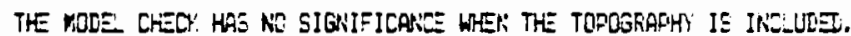

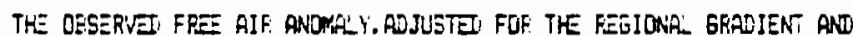
THE TERRAIV: WIERE AFFROPRIATE, IS COMEARET TO THE CALCULATE TOT. THE COMFARISON IS WADE R' EQUILIERATIN THE VEFTICAL SCOLES (IN MGRLS) FOF DESFAH ANU TOT AT TIE PROFEF MATCH FOINT (IE. WHERE TRE DRIGINL: EEST FIT WRS RADE EETWEEN THE OESEFVEU ANU THE CLLCULATE DATAI. DOESFA IS THE AMOUHT THAT TOT (ADJUSTEU FOT THE SCALE CHANGE) IS GREATER THAN(FOEITIVE VRUUS) OF LESS THAN (NEGATIVE VRLLES) THE OESFAA RT R GIVEN CALQRATEI FOINT.

100 DKCX COMENT CARO

$110 C$ GRADS FIRST FEGIOHO ERODIENT F10.0

IEOC GRADE SECONW FEGICHA. GRADIENT F10.0

IJOE GRADS CHANEE IN REOIONR GRADIENT F10.0

1400 SAM CROSE EEETJOP. NUMEER F10.0

SSOC $Y$ TOTR NLMEF, OF CONPUTEI POINTS IS

1600 $N$ TOTR NUMEEF OF ELOCKS IN KONEI IS

170 FX $X$ COJRDINATE OF CALCULTT FOINT FIO.0

IBOC FI 2 COORDINATE OF CFLQLLATE FDINT F10.0

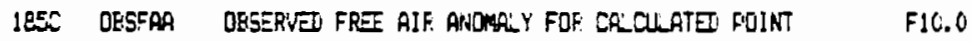

1900 RHD ELDO DENSITY FI.

200C $J$ NUMBEF OF CORERE IN ELOOK

2100 ISRT ELOCK NLMBER IS

FOO $X$ X COOPDINATE OF BLOEK CORNEF F10.0

230E I I CODPDINATE OF E.OOY. CORNER FIO.O

2405

3500

2600

270 DIENSION FX (200), FZ(200), X(400), Z(400), TOT (Z(X)), TIT (200), DRCX (20)

275\& , OESFAA E(X)!, DOESFAR(EOO)

280 REAU $(22,901)$ (DROX $(3), J=1,20)$

2904901 FORMRT (2094)

300 HRITE $(23,502)(D R C X(J), J=1,20)$

310\#90E FOFAAT ' 'I',20A4///)

32(H100 READ (2E,465) GADDL, GRADE, GKRDS, GRRDA, GROD, GRADO, GRADE

330 H69 FORAT $\{7 F 10.0\}$

30

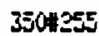

If (6RADS) $35.95 g E, 3$

WRITE ( 23,468 ) GRAD:, GRADE, GRADE. GRADA, GRAD, GRADO. GRADE

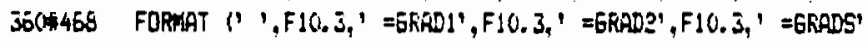

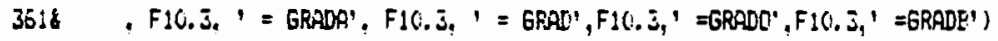

$370 \quad P I=3.1415527$

380 FITE=E. \#FI

290 REAT (2:.1) SAT, R.N

400\%1 FORMAT (FIO. 0.2.5) 


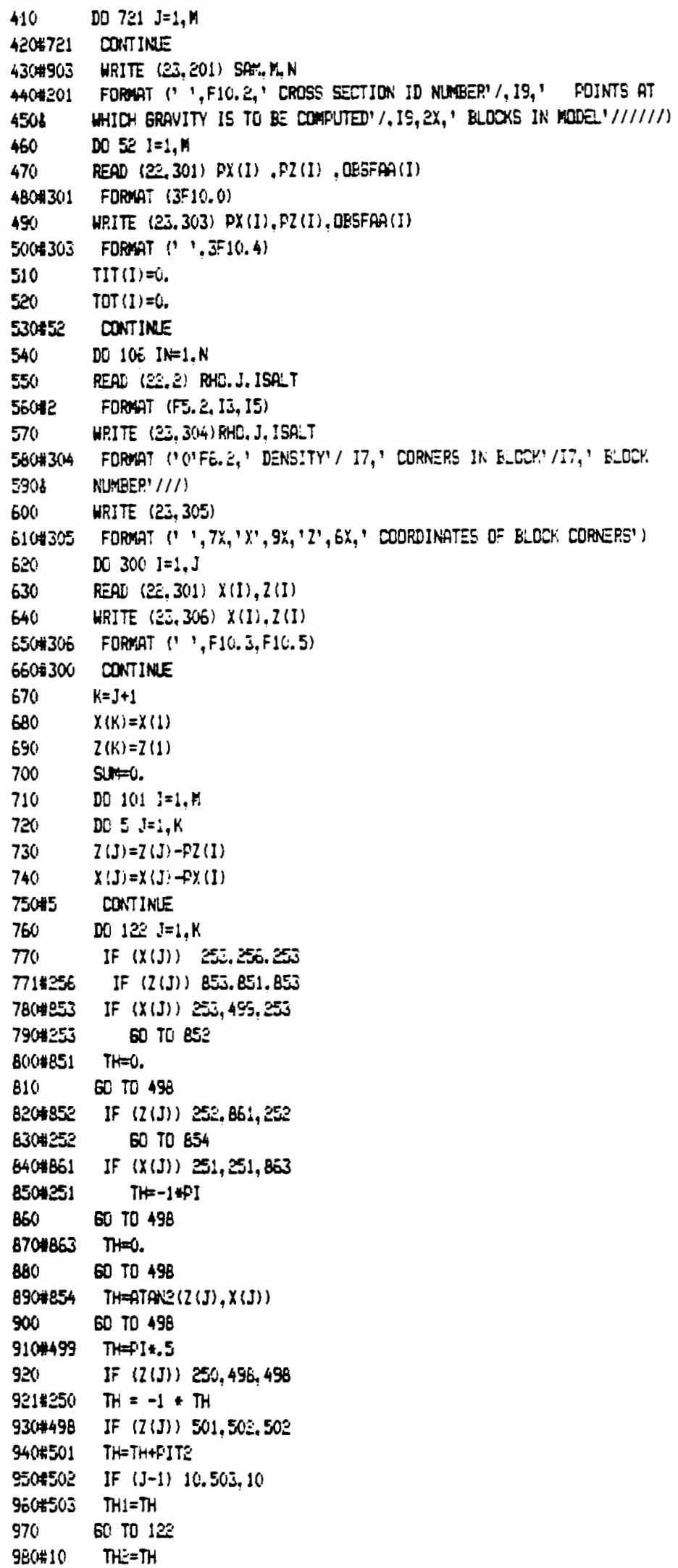




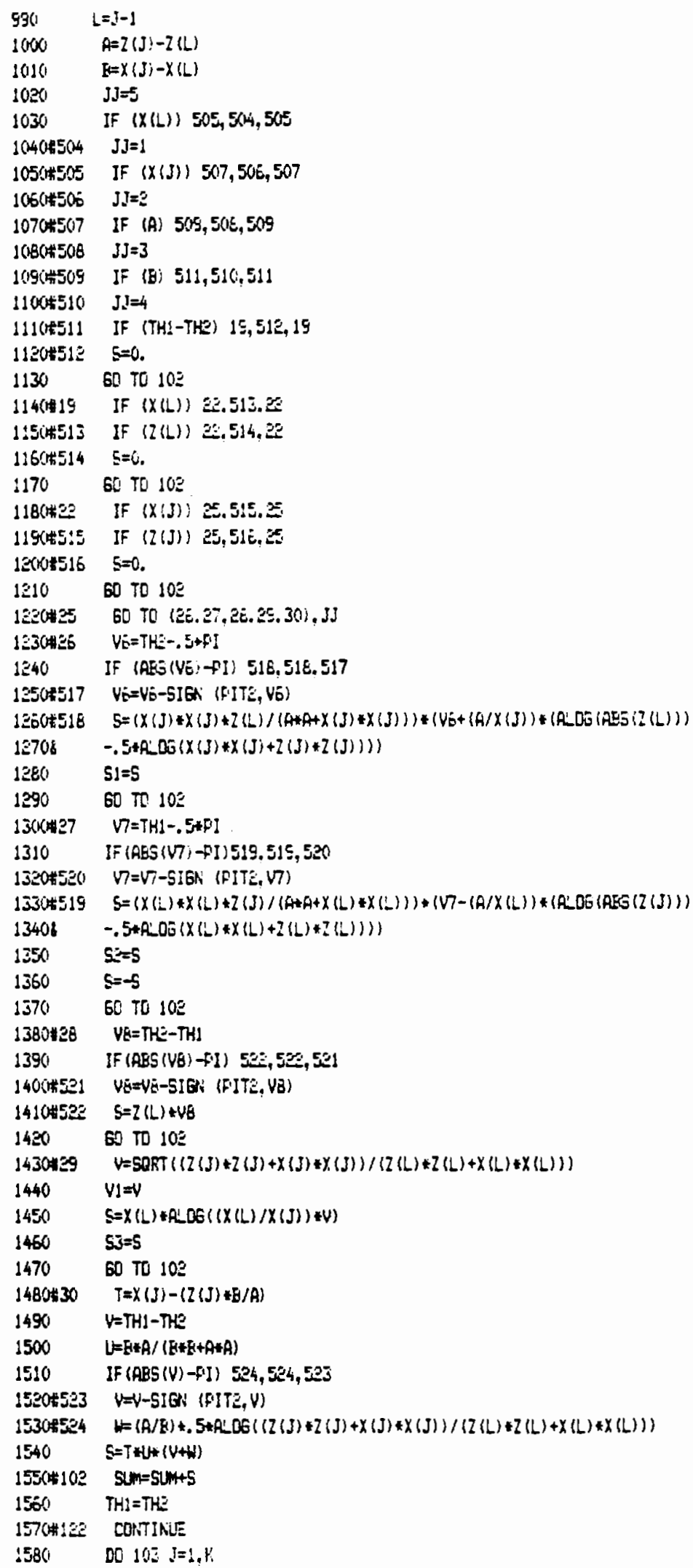




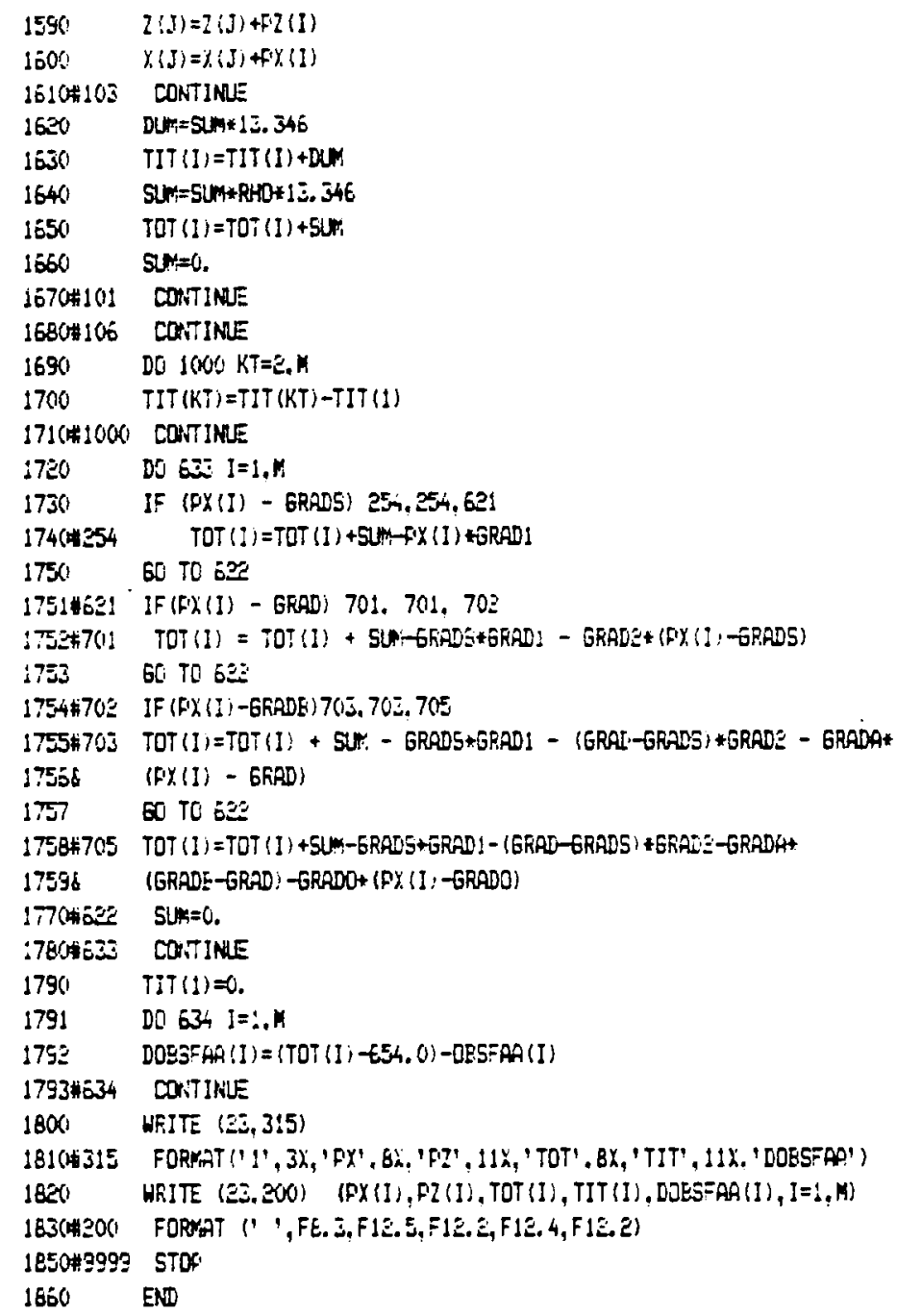


APPENDIX B

CROSS-SECTIONS USED IN

TERRAIN CORRECTION DETERMINATIONS 


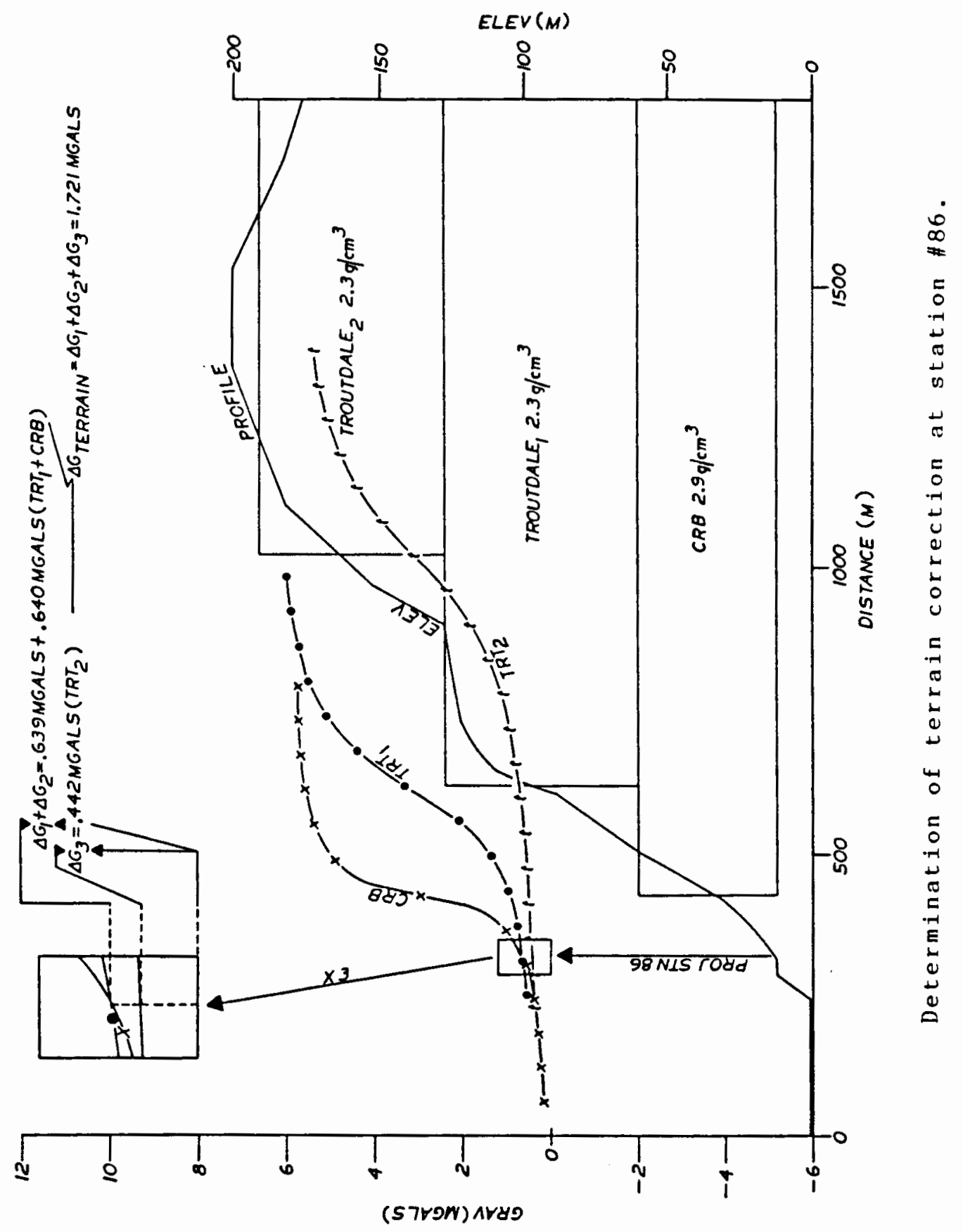




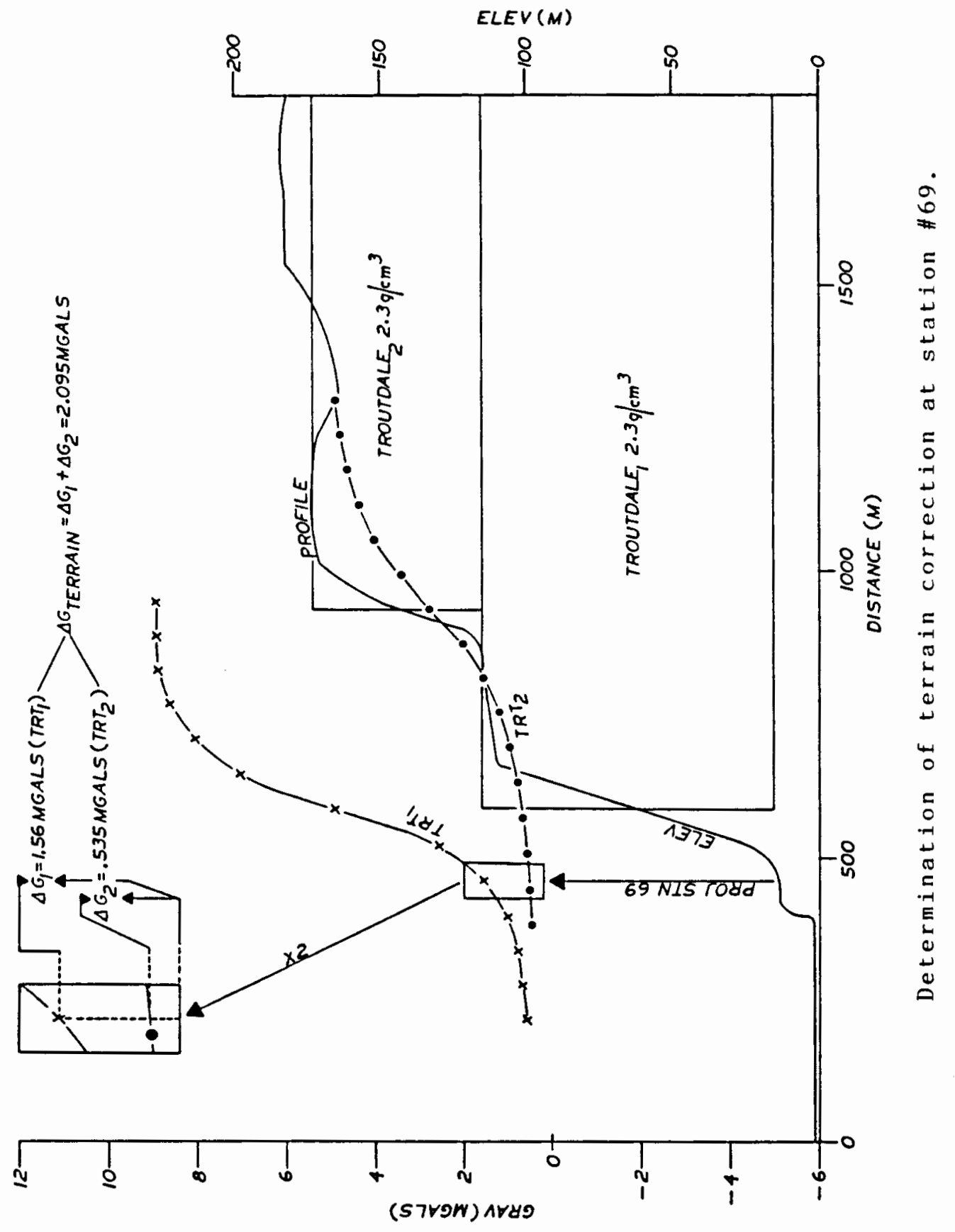




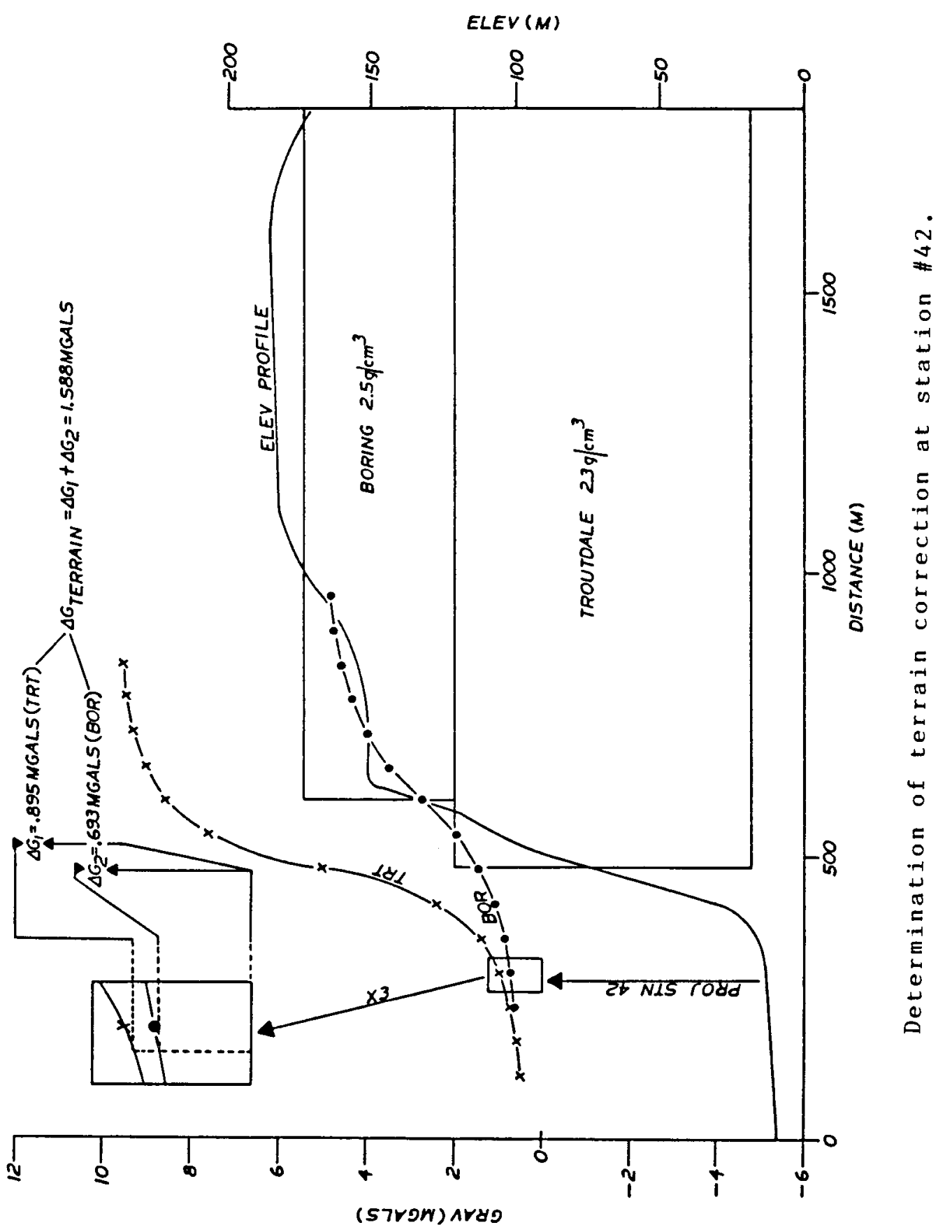




\section{APPENDIX C}

GEOPHYSICAL DATA 
TERRAIN CORRECTION VALUES

INTERSTATE LINE

\begin{tabular}{|c|c|c|c|}
\hline $\begin{array}{l}\text { STATION } \\
\text { NUMBER }\end{array}$ & $\begin{array}{l}\text { TERRAIN } \\
\text { CORREC- } \\
\text { MGALS }\end{array}$ & $\begin{array}{l}\text { STATION } \\
\text { NUMBER }\end{array}$ & $\begin{array}{l}\text { TERRAIN } \\
\text { CORREC- } \\
\text { MGALS }\end{array}$ \\
\hline 23 & 0.12 & 61 & 2.00 \\
\hline 24 & 0.35 & 62 & 1.88 \\
\hline 25 & 0.44 & 63 & 1.70 \\
\hline 26 & 0.57 & 64 & 1.73 \\
\hline 27 & 0.67 & 65 & 1.78 \\
\hline 28 & 0.77 & 66 & 1.82 \\
\hline 29 & 0.88 & 67 & 1.93 \\
\hline 30 & 1.00 & 68 & 2.20 \\
\hline 31 & 1.10 & 69 & 2.08 \\
\hline 32 & 1.22 & 71 & 1.99 \\
\hline 33 & 1.34 & 72 & 1.93 \\
\hline 34 & 1.45 & 73 & 1.90 \\
\hline 35 & 1.55 & 74 & 1.87 \\
\hline 36 & 1.55 & 75 & 1.66 \\
\hline 37 & 1.55 & 76 & 1.47 \\
\hline 38 & 1.55 & 77 & 1.30 \\
\hline 39 & 1.55 & 78 & 1.12 \\
\hline 40 & 1.55 & 79 & 1.20 \\
\hline 41 & 1.55 & 80 & 1.26 \\
\hline 42 & 1.55 & 81 & 1.36 \\
\hline 43 & 1.68 & 82 & 1.45 \\
\hline 44 & 1.84 & 83 & 1.50 \\
\hline 45 & 1.97 & 85 & 1.63 \\
\hline 46 & 2.15 & 86 & 1.72 \\
\hline 47 & 2.29 & 87 & 1.80 \\
\hline 48 & 2.44 & 88 & 1.85 \\
\hline 49 & 2.58 & 89 & 1.91 \\
\hline 50 & 2.72 & 90 & 1.97 \\
\hline 51 & 2.82 & 91 & 2.06 \\
\hline 52 & 2.93 & & \\
\hline 53 & 3.05 & & \\
\hline 54 & 3.17 & & \\
\hline 55 & 3.10 & & \\
\hline 56 & 2.88 & & \\
\hline 57 & 2.70 & & \\
\hline 58 & 2.52 & & \\
\hline 59 & 2.16 & & \\
\hline 60 & 2.16 & & \\
\hline
\end{tabular}




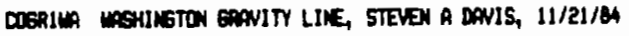

O LINES TO RE PRINTED OY SEROUTIE PLTRI

WD COSTANTS USED TO CR CLLTE THEDETIICA ERNITY

\begin{tabular}{|c|c|c|c|c|c|c|c|c|c|c|c|c|}
\hline $\begin{array}{l}\text { TATION } \\
\text { WuaraR }\end{array}$ & न्सा & NETES & 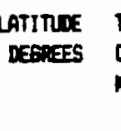 & $\begin{array}{l}\text { IEREaIN } \\
\text { corper. } \\
\text { vefts }\end{array}$ & $\begin{array}{l}\text { Desenved } \\
\text { ERovity } \\
\text { nas }\end{array}$ & $\begin{array}{l}\text { TEOIETICOL } \\
\text { EANIT } \\
\text { nens }\end{array}$ & $\underset{\text { CORES. }}{\text { Cores }}$ & $\underset{\max }{\operatorname{coses}}$ & $\begin{array}{l}\text { FRE RIR } \\
\text { AmALY } \\
\text { nexs }\end{array}$ & 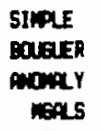 & 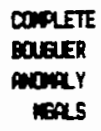 & \\
\hline .0 & 476.61 & $190.0 r$ & 45.72130 & .000 & 590622.00 & 590694.43 & 16.24 & 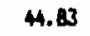 & -27.60 & -43.84 & -43.84 & 122.45420 \\
\hline & & & 45.71810 & .000 & 900622,38 & 900694.14 & 15.95 & 44.03 & -27.73 & -13.68 & -43.68 & 122.45430 \\
\hline 3.0 & 6.54 & 35 & 71690 & .000 & 590620.13 & 990694.03 & 16.9 & 46.70 & -27.20 & -4.11 & -4.11 & 120.45430 \\
\hline 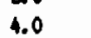 & & & 71620 & .000 & 990620.11 & 900693.97 & 16.95 & 46.79 & 27.07 & & -4.02 & 122.45430 \\
\hline 5.0 & & & 71520 & .000 & 990621.34 & 980593.88 & 16. 31 & 45.02 & -27.52 & -43.82 & -43.02 & 122.45430 \\
\hline 6.0 & 6. 34 & 136.65 & 45.71190 & .000 & 980623,33 & 500693.58 & 15.27 & 42.17 & 28.08 & -43.35 & -43.55 & 122.45430 \\
\hline 7.0 & 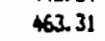 & & 45.70080 & .000 & 980621.50 & 980693.30 & 15.78 & 43.58 & -26.22 & -4.01 & -4.01 & 5430 \\
\hline 6.0 & 462.64 & .01 & 45.70560 & .000 & 900620.87 & 990693.01 & 15.76 & 43.52 & -28.63 & -44.39 & +4.39 & 122.45430 \\
\hline 9.0 & 160 & & .70230 & .000 & 900620.71 & 900692.71 & 15.68 & 43.28 & -28.73 & -44.40 & -4.40 & 122.45430 \\
\hline 10.0 & 3.0 & & 70160 & .000 & 980620.68 & 980652.65 & 5.61 & 3.09 & -28.88 & -4.49 & -4.49 & 5420 \\
\hline I. & & & .70160 & .000 & 900621.48 & 980632.65 & 15.10 & 11.70 & -29.47 & -4.57 & -4.57 & 128.45750 \\
\hline 12.0 & & & 70160 & .000 & 60622.49 & 990692.65 & 14.3 & 39.54 & -30.62 & -44.94 & -44.94 & 122.46010 \\
\hline 13.0 & & & 70160 & .000 & $20<23.52$ & $\operatorname{sec6se~} 65$ & 3.30 & 6.72 & -32.42 & -45.71 & -45.71 & 122.46300 \\
\hline 14.0 & & & 70160 & .000 & 60628.39 & 980692.65 & 0.59 & 29.24 & -35.02 & -45.61 & -45.61 & 6760 \\
\hline 15. & & & & .000 & 90628.66 & 990692.62 & 10.44 & & -35.15 & -45.58 & -45.50 & 6840 \\
\hline 16. & & & & .000 & 30629.04 & 990692.51 & 10.09 & & -35.61 & -45.70 & -45.70 & 590 \\
\hline 17. & & & 69990 & .000 & 9.37 & 580692.50 & 9.83 & & -35.98 & -45.81 & -45.81 & 7030 \\
\hline 16. & .66 & & 10010 & .0 & 0628.11 & se06se 52 & 10.28 & 8. 37 & -36.03 & -46.31 & 46.31 & \\
\hline 19. & & & 69990 & .000 & 10627.27 & 900692.50 & .60 & 9.27 & 55.9 & -46.56 & 16.56 & 100 \\
\hline 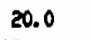 & & & 9950 & .000 & 590527.94 & 990652.46 & 10.10 & 7.69 & 36.63 & -46.73 & -46.73 & 820 \\
\hline 21.0 & & & 59560 & .000 & 980628.69 & 580652.47 & 57 & 26.43 & -37.35 & -46.92 & -46.92 & 160 \\
\hline$m$ & & & 9970 & .000 & 00629.76 & seose 48 & 6.82 & 24.35 & -38.36 & -47.18 & -47.18 & 370 \\
\hline 38 & & & 9980 & .000 & 0629.55 & 90069.40 & 8.79 & 24.27 & -38.56 & -47.37 & -47.37 & 3500 \\
\hline 24 & & & 3900 & .000 & 0629.76 & seosse. 33 & 8.61 & 23.78 & -38.78 & -47.40 & -47.40 & 8710 \\
\hline 25. & & & 9690 & .000 & 90629.67 & 980592.23 & 8.59 & 23.73 & -38.83 & -47.42 & -17.42 & 8940 \\
\hline 26.0 & & & 69500 & .000 & 00629.71 & 900592.10 & 4.56 & 23.62 & -38.77 & -47.2 & -47.32 & 9090 \\
\hline 27.0 & .24 & & 9430 & .000 & 30629.80 & 900691.99 & Q.53 & 23.54 & -38.65 & -47.18 & -47.18 & 9230 \\
\hline 26. & 3.84 & & 230 & .000 & 00629.94 & 30691.81 & 0.46 & 23.41 & -38.47 & -46.94 & -46.94 & 9450 \\
\hline 29. & & & 9040 & .000 & 0629.37 & 0691.64 & 60 & .73 & 38.54 & & -47.13 & 500 \\
\hline 30. & & & 60990 & .000 & 30529.07 & 900691.59 & 0.69 & 3.9 & -38.53 & +7.22 & -47.22 & 9680 \\
\hline 31. & & & 60940 & .000 & 20029.01 & 980591.55 & 270 & 24.01 & -38.53 & -67.23 & -47.23 & $9 \pi 70$ \\
\hline 32.0 & 67 & & 2880 & .000 & 20528.92 & 30691.50 & 0.71 & 4.94 & -38.54 & -47.24 & -47.24 & 9870 \\
\hline 33.0 & & & 8980 &.$\infty$ & 30628.84 & 980691.44 & 6.74 & 24.12 & -38.46 & -47.22 & -47.22 & 970 \\
\hline 34. & .50 & & 8770 &.$\infty$ & 1062879 & 980691.40 & 73 & 24.11 & 32.49 & -47.23 & -47.23 & 060 \\
\hline 30.0 & 1.64 & & 700 & .00 & 0628.75 & 980691.35 & $r$ & 24.06 & -38.54 & -47 & -47.25 & \\
\hline 36.0 & م. & & 2660 & .000 & 00628.59 & 900691.30 & 73 & 64.11 & -38.59 & -47.33 & -47.33 & \\
\hline 37.0 & & & $\$ 610$ & .000 & 00628.51 & 990691.25 & 76 & & -38.56 & -47.32 & -47.32 & 0350 \\
\hline 30.0 & & & & . & 300628.37 & 900591.20 & 79 & .26 & -38.57 & -47.36 & -47.36 & 450 \\
\hline 39.0 & & & 490 & .000 & 980528,00 & 900691.14 & Le & 24.41 & -38.66 & -47.50 & -47.50 & 0050 \\
\hline 40.0 & & & & .000 & $20527 . \%$ & 930691.09 & 64 & 24.40 & -38.73 & -47.57 & -67.57 & 0650 \\
\hline 41.0 & & & .68380 & .000 & 80627.76 & 990691.04 & 8.80 & 24.30 & -38.98 & -47.78 & -47.78 & 0750 \\
\hline 42.0 & & .58 & 68200 & .000 & 940627.65 & 980590.99 & 6.78 & 24.25 & -39.08 & -47.86 & -47.86 & 122.50040 \\
\hline 43.0 & 6.97 & 32 & 60260 & .000 & 940627.54 & 980690.94 & 4.75 & 24.17 & & -47.98 & -47.98 & 50950 \\
\hline 4.0 & .48 & & 68200 & .000 & $\sec \leq 27.74$ & 990690.88 & .74 & 24.12 & $\alpha$ & -47.76 & -47.76 & 1050 \\
\hline 45.0 & & & 45.68150 & .000 & 900627.80 & 980690.84 & 3.69 & 24.00 & & -47.73 & -47.73 & 1150 \\
\hline 46.0 & & & 45.68090 & .000 & $\operatorname{sec627.87}$ & 990690.78 & 163 & 23.83 & -39.09 & -47.72 & -47.72 & 122 \\
\hline 1.0 & {$[.313$} & & 45.68040 & .00 & $\pi$ & 690.74 & .60 & 73 & 23 & -47.03 & -47.03 & \\
\hline 48.0 & .3 & 6 & 960 & $\infty$ & 2627.80 & 980690.67 & 6 & $23 . \mathrm{En}$ & $-33,2$ & -47.79 & -47.70 & $122.51 \mathrm{M}$ \\
\hline
\end{tabular}




\begin{tabular}{|c|c|c|c|c|c|c|c|c|c|c|c|c|}
\hline 1.0 & 250.93 & 76.46 & 45.67900 & .000 & 0627.82 & 980690.61 & 5 & 23.60 & -39.19 & -47.74 & -47.74 & 122.51600 \\
\hline 50.0 & 45.69 & 1.89 & 67810 & 000 & 30628.06 & 0690.53 & & 23.11 & -39.34 & -47.71 & -47.71 & 122.51670 \\
\hline 51.0 & 37.56 & .53 & 690 & .000 & 90628.85 & 80690.42 & 1 & 38 & -39.19 & -47.30 & -47.30 & 122.51750 \\
\hline 52.0 & $5 \pi$ & .86 & 510 & .000 & 80628.40 & 30690.35 & .03 & .18 & -39.7 & -47.81 & -47.81 & 122.51790 \\
\hline 53.0 & $x$ & 1.04 & 67530 & .000 & 60628.45 & 30690.28 & 94 & .92 & -39.91 & -47.65 & -47.65 & 122.51840 \\
\hline 5.0 & 21.09 & .39 & .67330 & .000 & $\operatorname{sareg} .39$ & 0590.10 & 53 & 0.80 & -339.91 & -347.44 & -347.44 & 122.51950 \\
\hline 56.0 & 19.12 & 6.79 & 77280 & .000 & 980629.74 & 00650.05 & 47 & 20.61 & -39.70 & -47.17 & -47.17 & 122.52040 \\
\hline 57.0 & 18.80 & 66.69 & .67290 & .000 & 590630.52 & 900690.06 & 45 & 20.58 & -38.96 & -46.41 & $-46,41$ & 122.52300 \\
\hline 58.0 & 19.14 & 6.79 & 45.67290 & .000 & 900634.24 & 980690.06 & 7.47 & 20.61 & -38.21 & -45.67 & $-\$ 5.67$ & 122.52500 \\
\hline 59.0 & 19.69 & 6.5 & 45.67290 & .000 & 900631.78 & 900690.06 & .48 & 20.66 & -37.62 & -45.10 & -45.10 & 122.52750 \\
\hline 60.0 & 21.28 & 7.45 & 45.67290 & .000 & 980631.48 & 900690.06 & .54 & 20.81 & -37.7 & & -45.31 & 122.52960 \\
\hline 1.0 & 16.68 & 66.04 & 45.67240 & .000 & 920631.93 & 990690.02 & .38 & 20.38 & -37.70 & -45.09 & -45.09 & 122.53200 \\
\hline 2.0 & 12.74 & 64.84 & 45.67190 & .000 & 900632.42 & 900689.97 & 7.25 & 20.02 & -37.54 & -44.79 & -4.79 & 122.53400 \\
\hline 63.0 & 09.06 & 63.73 & 45.67130 & .000 & 900628.42 & 580689.92 & .12 & 19.67 & -37.43 & -44.55 & -4.55 & 122.53640 \\
\hline 64.0 & 08.01 & 63.40 & 45.67000 & .000 & 980633.37 & 900649.87 & 7.09 & 19.57 & -36.94 & -44.02 & -4.02 & 122.53820 \\
\hline 55.0 & 77.92 & 63.37 & 45.67030 & .000 & 980633.73 & 900609.23 & 7.06 & 19.56 & -36.54 & -43.62 & -43.62 & 122.54040 \\
\hline 5.0 & 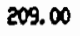 & .70 & 45.66970 & .000 & 900634.03 & 980689.77 & 2 & .66 & -36.08 & -43.20 & -13.20 & 122.54260 \\
\hline 7.0 & 40 & 8 & 45.66900 & .000 & 980534,40 & 80689.73 & 7. & 19.70 & -35.63 & -42.76 & -42.76 & 122.54400 \\
\hline 58.0 & & 4.06 & 45.66860 & .000 & 980634.68 & 980689.67 & 14 & 19.7 & -3.22 & -42.38 & -42.38 & 122.54690 \\
\hline 69. & 13.85 & 65.18 & 45.66780 & .000 & 990634.54 & 980689.60 & 7.29 & 20.11 & -34.95 & -42.23 & -42.2 & 122.55020 \\
\hline
\end{tabular}




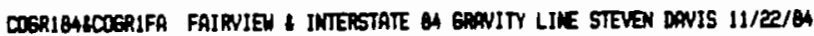

- LIESS TO BE PRIKTE BY SCROUTINE RTRI

D CONSTATS LEED TO CRLCLATE THEDETICR ERANIT

\begin{tabular}{|c|c|c|c|c|c|c|c|c|c|c|c|c|}
\hline $\begin{array}{l}\text { STRTICN } \\
\text { MUBER }\end{array}$ & $\begin{array}{l}\text { בEWAT } \\
\text { FEET }\end{array}$ & AETERS & $\begin{array}{l}\text { LATITINE } \\
\text { DEGRGES }\end{array}$ & $\begin{array}{l}\text { TERPAIN } \\
\text { coRREC. } \\
\text { ner.s }\end{array}$ & 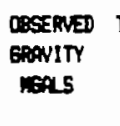 & $\begin{array}{l}\text { REDPETICR } \\
\text { GROWITY } \\
\text { MEAS }\end{array}$ & $\begin{array}{l}\text { BOUGER } \\
\text { CORPEL. } \\
\text { WERLS }\end{array}$ & $\begin{array}{l}\text { FREE AIR } \\
\text { CORRaC. } \\
\text { IEALS }\end{array}$ & $\begin{array}{l}\text { FRE AIR } \\
\text { WIPLY } \\
\text { WEAS }\end{array}$ & $\begin{array}{l}\text { SINPLE } \\
\text { BOWAER } \\
\text { AOWHYY } \\
\text { HEPLS }\end{array}$ & $\begin{array}{l}\text { COPLETE } \\
\text { BOAEER } \\
\text { ATIRYY } \\
\text { WERLS }\end{array}$ & \\
\hline 94.0 & 41.61 & 12.68 & 45.54280 & .000 & 500630.18 & 980678.32 & 1.42 & 3.91 & -39.22 & -40.64 & -40.64 & 122.42850 \\
\hline 55.0 & 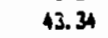 & 13.21 & 54290 & .000 & $980635.3 !$ & 990678.33 & 1.48 & 4.08 & -38.94 & -40.4 & -40.42 & 122.42610 \\
\hline 96.0 & 50.76 & 6.47 & 45.54300 & .000 & 980635.10 & 980678.34 & 1.73 & 4.77 & -38.46 & -40.19 & -40.19 & 122.42410 \\
\hline 97.0 & 66.23 & 20.19 & 45.54310 & .000 & 900634.04 & 980678.34 & 2.26 & 6.23 & -38.08 & -40.33 & -40.33 & 122.42000 \\
\hline 98.0 & 76.37 & 23.28 & 45.54270 & .000 & 980633.32 & 900678.31 & 2.60 & 7.18 & -37.81 & -4.41 & -40.41 & 122.41700 \\
\hline 101. & X. 87 & 25.31 & 45.53960 & .000 & 980531.69 & 980678.03 & 3.16 & 8.74 & -37.60 & $-\infty .77$ & -40.7 & 122.41680 \\
\hline 102. & B3. 14 & 25.34 & 45.54040 & .000 & 99062.39 & 980678.10 & 2.63 & 7.82 & -37.89 & -40.72 & -40.72 & 122.41480 \\
\hline 103. & 3.91 & 23.4 & 45.54110 & .000 & $980628 . \pi$ & 980578.15 & 2.62 & 7.23 & -38.16 & -40.78 & -40.78 & 122.41270 \\
\hline 104. & .02 & 20.43 & 45.54190 & .000 & 900633.40 & 990678.24 & 2.28 & 6.30 & -38.53 & -40.82 & -40.82 & 122,41000 \\
\hline .060 & 52. 16 & 17.73 & 45.54230 & .000 & 900633.84 & 990678.27 & 1.98 & 5.47 & -38.56 & -40.94 & -40.94 & 122.40970 \\
\hline .070 & 48.88 & 14.90 & 45. 54270 & .000 & 990634.58 & 900678.31 & 1.67 & 4,60 & -39.13 & -40.60 & -40.80 & 12.40660 \\
\hline .080 & 39.26 & 1.97 & 45,54310 & .000 & 98063518 & 990678.34 & 1.34 & 3.69 & -39.47 & -40.81 & -40.81 & 122.40750 \\
\hline .090 & & .20 & 5.54390 & .000 & 5.78 & 990678.42 & 1.14 & 3.15 & -39.49 & -40.63 & -40.63 & 0570 \\
\hline 2.0 & & 6 & 400 & .000 & 5.4 & 900678.43 & 1.18 & 3.26 & -39.73 & -40.91 & -40.91 & 370 \\
\hline $3, \infty$ & .28 & 12.28 & 45.54430 & .000 & 900534,96 & 960678.45 & 1.37 & 3.79 & -39.70 & 1.08 & -41.08 & 122 \\
\hline 4.0 & 26 & 13.19 & $5.54+40$ & .000 & 900534.66 & 960678.46 & 1.47 & 4.07 & -39.73 & 1.21 & -41.21 & 0170 \\
\hline $5 . \infty$ & 10 & 13.75 & 45.5430 & .000 & 900634.56 & 900678.45 & 1.54 & 4.24 & -39.65 & -41.19 & -11.19 & 128.40030 \\
\hline 7.00 & .30 & .11 & 45.54450 & .000 & 900534.36 & 980678.47 & 1.56 & 4.35 & -39.76 & -41.33 & -41.33 & 122. 39780 \\
\hline 8.00 & $u$ & 75 & 45.54450 & .000 & 990534.45 & 980678.47 & 1.54 & 4.24 & -39.78 & -41.31 & -41.31 & 122. 39670 \\
\hline 9.00 & 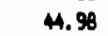 & .71 & $45.5+460$ & .000 & 990634.51 & 980678.48 & 1.53 & 4.23 & -39.74 & -41.27 & -41.27 & 122.39540 \\
\hline 10.0 & 0 & 672 & 5.54470 & .000 & 80634.71 & 990678.49 & 1.53 & 4.23 & -39.55 & -11.08 & -41.08 & 122.39420 \\
\hline 11. & $2 n$ & -81 & 2.54470 & .000 & 80634.54 & 990678.49 & 1.54 & 4.26 & -39.69 & -41.23 & -41.23 & 122.39300 \\
\hline 12.0 & .65 & .52 & 2.54400 & .000 & 30634.37 & 980678.50 & 1.62 & 4.48 & -39.65 & -11.27 & -41.27 & 122.39170 \\
\hline 13.0 & .90 & .51 & 45.54400 & .000 & 30534.19 & 590678.50 & 1.73 & 4.79 & -39.52 & -11.25 & -41.25 & 122. \\
\hline 14.0 & & .62 & 45.54490 & .000 & 0634,09 & 990678.51 & $1 . \pi$ & 4.80 & -39.54 & -41.30 & -41.30 & 122.39900 \\
\hline 15.0 & c7 & 14 & $54+60$ & .000 & 10634.16 & 980678.50 & 1.69 & 4.67 & -39.67 & -41.36 & -41.36 & 122.38770 \\
\hline 16.0 & b. & .13 & 54480 & .000 & 30634.12 & 980678.50 & 1.58 & 4.36 & -40.02 & -41.60 & -41.60 & 122.39650 \\
\hline 17.0 & 60 & 59 & 5.54470 & .000 & 80634.18 & 980678.49 & 1.52 & 4.20 & -40.11 & -41.63 & -41.63 & 122,38540 \\
\hline 18.0 & .23 & .48 & 40 & 000 & $0 \leq 533.45$ & 590576.46 & 1.51 & 4.16 & -40.65 & 36 & -42.36 & 122. \\
\hline 19.0 & 4 & 5 & & 000 & 45 & 500578.45 & 31 & 7 & -40.83 & -42.34 & -42.34 & 120 \\
\hline 20. & & & & 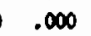 & 48 & 39067 & i & & 82 & 32 & 232 & 122. \\
\hline 2 & & & & 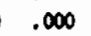 & & 2.44 & 9 & & & $\sqrt{18}$ & 48 & 790 \\
\hline$\omega$ & & & & 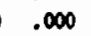 & 3.29 & 990678.4 & 16 & & & 87 & .57 & 7670 \\
\hline 23. & & & 400 & .00 & 0033.81 & 90678.43 & 1.36 & 3.75 & -40.87 & -4222 & -4222 & 122.37550 \\
\hline 24. & & & 4390 & .000 & 80533.64 & 990578.42 & 1.46 & 4.03 & -40.75 & -42.21 & -42.21 & 122.37430 \\
\hline 250 & & & 430 & .000 & 0533.39 & 900676.41 & 1.46 & 4,02 & -41.00 & -42.46 & -42.46 & 455,37300 \\
\hline 26.0 & & 2.02 & 5430 & .000 & 30633.29 & 990678.40 & 1.46 & 4.02 & -41.09 & -42.5 & -42.55 & 122.37160 \\
\hline 27.0 & .50 & 12.5 & .54370 & .000 & 00633.06 & 980678.40 & 1.45 & $4 . \infty$ & -41.34 & -42.79 & -42.79 & 122. \\
\hline 29.0 & .89 & $12 \pi$ & 54360 & .000 & 00633.02 & 990576.39 & 1.43 & 3.94 & -41.43 & -12.86 & -12.86 & 122.36900 \\
\hline 29.0 & 41.87 & 12.76 & 45.54350 & .000 & 98063308 & 990676.38 & 1,43 & 3.94 & -41.36 & -42.79 & -42.79 & 122.35790 \\
\hline 30.0 & 41.1 & 12.55 & 45.54340 & .000 & $\operatorname{sec633} 09$ & 980678.37 & 1.40 & 3.87 & -41.41 & -42.81 & -42.81 & 122,36660 \\
\hline 31. & 4 & 12.46 & 45.54300 & .000 & 990633,15 & 990678.36 & 1.39 & 3.65 & -41.37 & -12.76 & -42.76 & 122.36530 \\
\hline 3. & + & 12.44 & 54320 & .000 & 980633.25 & 980678.35 & 1.39 & 3.84 & & -42.66 & -42.66 & 122,35410 \\
\hline 33. & 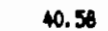 & 12.37 & & .000 & 0633.41 & 990578.34 & 1.30 & 182 & & -42.50 & -42.50 & 122,36200 \\
\hline 34. & & .79 & & .000 & .50 & 990676.34 & 1.43 & .55 & -40.89 & -42.32 & -432 & 122 \\
\hline s. & & .86 & & .00 & 00633.52 & 580578.33 & 1.4 & .97 & -40.84 & -42.28 & -42.28 & 080 \\
\hline 36.0 & 2.17 & $12.0^{5}$ & 45. 5428 & .000 & 990633.58 & 990675.32 & 1.4 & 3.97 & -40.7 & -42.21 & -42.21 & 12.35890 \\
\hline
\end{tabular}




\begin{tabular}{|c|c|c|c|c|c|c|c|c|c|c|c|c|}
\hline 7.0 & 42.09 & 12.85 & 45.54270 & .000 & 98053354 & 590678.31 & 1.43 & 3.86 & -40.81 & -42.24 & -42.24 & 12253760 \\
\hline 36.0 & 42.08 & 12.83 & 45.54270 & .000 & 980533.46 & 980678.31 & 1.43 & 3.96 & -40.69 & -42.32 & -42.32 & 122.35630 \\
\hline 39.0 & 41.71 & 12.71 & 45.54260 & .000 & 980633.33 & 990578.30 & 1.42 & 3.52 & -11.05 & -42.47 & -42.47 & $12 x^{2} 3510$ \\
\hline 40.0 & 41.71 & 12.71 & 45.54250 &., 000 & 900635,36 & 990678.29 & 1.42 & 3.92 & -41.01 & -42.43 & -42.43 & 122,35370 \\
\hline 41.0 & 42.29 & 12.89 & 45.54240 & .000 & 900533.28 & 990678.28 & 1.4 & 3.98 & -11.02 & -42.46 & -42.46 & 122.35240 \\
\hline 42.0 & 42.21 & 12.87 & 45.54230 & .000 & 990633.17 & 980678.27 & 1.4 & 3.97 & -41.13 & -42.57 & -42.57 & 122.35110 \\
\hline 43.0 & 42.26 & 12.88 & 45 SA220 & .000 & 980633.21 & 990678.26 & 1.44 & 3.97 & -11.08 & -42.52 & -42.52 & 122.34990 \\
\hline 4.0 & 41.46 & 12.64 & 45. 54210 & .000 & 9006274 & 990574.5 & 1.41 & 3.90 & -11.61 & -43.03 & -43.03 & 122,34650 \\
\hline 45.0 & 42.45 & 12.94 & 45.54200 & .000 & 99063268 & 900578.25 & 1.45 & 3.99 & -41.57 & -43.02 & -43.02 & 122.34720 \\
\hline 46.0 & 42.63 & 12.99 & 45. 54190 & .000 & 99063262 & 960678,24 & 1.45 & 4.01 & -41.61 & -43.06 & -43.06 & 122.34580 \\
\hline 47.0 & 42.80 & 13.05 & 45. 54180 & .000 & 900632.43 & 980678.23 & 1.46 & 4.03 & -41.77 & -43.23 & -43.23 & $122.34+50$ \\
\hline 40.0 & 43.58 & 13. 28 & 45. 54170 & .000 & 900632.18 & 500078.22 & 1.46 & 4.10 & -41.94 & -43.42 & -43.42 & 128.34220 \\
\hline 49.0 & 43.68 & 13.31 & 45.51150 & .000 & 99063201 & 900678.20 & 1.49 & 4.11 & -42.08 & -43.57 & -43.57 & 122.34200 \\
\hline 30.0 & 42.81 & 13.05 & 45.54130 & .000 & 980532 os & 980676.18 & 1.46 & 4.03 & -42.12 & -43.57 & -43.57 & 122.34000 \\
\hline 51.0 & 41.89 & 12.77 & 45.54100 & .000 & 900531.82 & 900676.16 & 1.43 & 3.94 & -42.40 & -43.82 & -43.82 & 122.33550 \\
\hline 52.0 & 41.69 & 12.71 & 45.54070 & .000 & 990631.97 & 980678.13 & 1.42 & 3.92 & -42.24 & -43.66 & -43.66 & 122.33930 \\
\hline 53.0 & 41.62 & 12.69 & 454040 & .000 & 980530.90 & 980678.10 & 1.42 & 3.91 & -43.29 & -44.70 & -44.70 & 122.33710 \\
\hline 54.0 & 41.64 & 12.69 & 45.54010 & .000 & 980630.33 & 980678.07 & 1.42 & 3.92 & -43.63 & -45.25 & -45.25 & 122.33590 \\
\hline 550 & 42.19 & 12.86 & 45.53930 & .000 & 980629.87 & 980678.05 & 1.44 & 3.97 & -44.21 & -45.65 & -45.65 & 122.33470 \\
\hline 56.0 & 42.53 & 12.96 & 45.53940 & .000 & 980628.90 & 980578.01 & 1.45 & 4.00 & -45.11 & -46.56 & -46.56 & 122.33340 \\
\hline 57.0 & 42.42 & 12.93 & 45.53920 & .000 & 900628.63 & 990677.99 & 1.45 & 3.99 & $-45,37$ & -46.82 & -46.82 & 12233220 \\
\hline 58.0 & 42.11 & 12.84 & 45.53900 & .000 & 980628,35 & 980677.97 & 1.43 & $3 . \%$ & -45.66 & -47.10 & -47.10 & 123.33090 \\
\hline 59.0 & .38 & 129 & 45. 53880 & .000 & 980628.21 & 9806 & 1.4 & 3.99 & -45.76 & -47.20 & -47.20 & 122.32960 \\
\hline 0.0 & 42.46 & 12.9 & 45.53460 & .000 & 990628.04 & 900677.94 & 1.45 & 3.99 & -4590 & -47.35 & -47.35 & 122. 32830 \\
\hline 61.0 & .50 & 12.55 & 45.53840 & .000 & 960627.86 & 900577.92 & 1.45 & 4.00 & -46.06 & -47.51 & -47.51 & 122.32710 \\
\hline 62.0 & .37 & 12.91 & 45.53830 & .000 & 980627.62 & 90067.91 & 1.44 & 3.99 & -46.31 & -47.5 & $-47 . \pi$ & 122.32580 \\
\hline 3.0 & .51 & 12.96 & 45,53820 & .000 & 980527.41 & 980577.90 & 1.45 & 4.00 & -46.49 & -47.94 & -47.94 & 122.240 \\
\hline 4.0 & .31 & 13.20 & 45.51620 & .000 & 980627.27 & 980576,10 & 1.46 & 4.07 & -44.75 & -46.23 & -46.23 & 122.32310 \\
\hline 65.0 & 65 & 13.30 & 45.53820 & .000 & 580627.19 & 7.50 & 1.49 & 4.11 & -46.61 & -48.09 & -48.09 & 12232170 \\
\hline 66.0 & 43.46 & 13.25 & 45.53620 & .000 & $9806 \times 5.87$ & 980677.90 & 1.48 & 4.09 & -46.94 & -48.42 & -48.42 & 12232040 \\
\hline 67.0 & 3.47 & 13.25 & 45.53820 & .000 & 980526.49 & 980577.90 & 1.48 & 4.09 & -47.32 & -48.80 & -48.80 & 122.31910 \\
\hline 68.0 & 62 & 13.30 & 45.53930 & .000 & 980526.37 & 980577.91 & 1.49 & 4.10 & -17.44 & -49.92 & -48.92 & 122. 31700 \\
\hline 69.0 & 23 & 13.19 & 45.53930 & .000 & 980626.42 & 980677.91 & 1.47 & 4.07 & $-47,42$ & -48.90 & -48.90 & 122.31650 \\
\hline 71.0 & 3.41 & 13.23 & 45. 53850 & .000 & 980626.48 & 98067.93 & 1.48 & 4.08 & -47.37 & -40.85 & -40.85 & 122.31390 \\
\hline 72.0 & 43.46 & 13.25 & 45.53860 & .000 & 980626.49 & 980677.9 & 1.46 & 4.09 & -47.36 & -40.84 & -46.84 & 122.31260 \\
\hline 73.0 & 42.90 & 3.08 & 45.53870 & .000 & 960626.50 & 980677.55 & 1.46 & 4.04 & -47.41 & -46.87 & -40.87 & 122.31130 \\
\hline 74.0 & .02 & 11 & 45.53870 & .000 & 980626.56 & 900 & 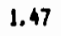 & 4. & 34 & -40.81 & -48.81 & 122.31000 \\
\hline 75.0 & 02 & S. II & 45. 53880 & .000 & 990625.40 & 580 & & 4.05 & -47.43 & -48.90 & -40.90 & 122.30060 \\
\hline 76.0 & 23 & 3. 18 & 45.53890 & .000 & 980626.62 & 9806 & 1.47 & 4.07 & -47.28 & -46.75 & -46.75 & 122.30730 \\
\hline$\pi .0$ & 37 & 13.22 & 45.53900 & .000 & 990626.83 & 9806 & 1.46 & 4.08 & -47.07 & -40.54 & -48.54 & 122.30600 \\
\hline 78.0 & 3.59 & 13.29 & 45.53910 & .000 & 990527.28 & 980677.98 & 1.49 & 4.10 & -46.60 & -40.09 & -40.09 & $122.3 \times 470$ \\
\hline 79.0 & 43.61 & 13.29 & 45.53930 & .000 & 980627.92 & 980678.00 & 1.49 & 4.10 & -45.98 & -47.47 & -47.47 & 122. 30340 \\
\hline 80.0 & 42.98 & 13.10 & 45.53950 & .000 & 980627.70 & 980678.0R & 1.46 & 4.04 & -46.28 & -47.74 & -47.74 & 122.30210 \\
\hline 81.0 & 3.00 & 13.11 & 45.53990 & .000 & 980527.88 & 980678,05 & 1.46 & 4.04 & -46.12 & -47.59 & -47.59 & 122.30090 \\
\hline 2.0 & 42.79 & 13.04 & 45,54020 & .000 & 980628.07 & 900678.06 & 1.46 & 4.02 & -45.99 & -47.45 & -47.45 & 122.29980 \\
\hline 83.0 & 4.60 & 13.01 & 45.54050 & .000 & 980628.50 & 990678.11 & 1.45 & 4.01 & -45.60 & -47.05 & -47.05 & 122.29740 \\
\hline 600 & 43.25 & 13.18 & 45.54130 & .000 & 980629.63 & 590672.18 & 1.47 & 4.07 & -4.46 & -45.96 & -45.96 & 12. 29380 \\
\hline 86.0 & 42.41 & 12.93 & 45.54140 & .000 & 980629.29 & 900678.19 & 1.4 & 3.99 & -4.91 & -46.36 & -46.36 & 122.29210 \\
\hline 87.0 & 42.44 & 12.94 & 45,54150 & .000 & 990630.25 & 2.20 & 1.45 & 3.99 & -43.96 & -45.40 & -45.40 & 122.28960 \\
\hline 88.0 & & 13.18 & 45.54160 & .000 & 990630.46 & 980678.21 & 1.47 & 4.07 & -43.68 & -45.15 & $-45,15$ & 122.28910 \\
\hline 89. & 3 & 13. & & .000 & 980629.5 & 990678.19 & 1.47 & 4.06 & -44.58 & -46.05 & -46.05 & 122.28610 \\
\hline 90.0 & 2.55 & 12.97 & & .000 & 380529.72 & 590578.18 & 1.45 & 4.00 & -4.46 & -45.91 & -45.91 & 122.28400 \\
\hline 91.0 & 43.84 & 13.36 & 45.54120 & .000 & 580629.73 & 900678.17 & 1.49 & 4.12 & -4.32 & -45.81 & -45.81 & 122.28190 \\
\hline
\end{tabular}

